\title{
Bismuth-Graphene Nanohybrids: Synthesis, Reaction Mechanisms, and Photocatalytic Applications-A Review
}

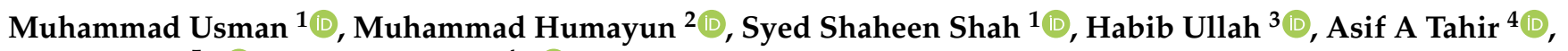 \\ Abbas Khan $5, *$ (D) and Habib Ullah ${ }^{4, *(D)}$ \\ 1 Center of Research Excellence in Nanotechnology, King Fahd University of Petroleum and Minerals (KFUPM), \\ Dhahran 31261, Saudi Arabia; muhammadu@kfupm.edu.sa (M.U.); g201709190@kfupm.edu.sa (S.S.S.) \\ 2 School of Optical and Electronic Information, Wuhan National Laboratory for Optoelectronics, \\ Huazhong University of Science and Technology, Wuhan 430074, China; 2017511018@hust.edu.cn \\ 3 State Key Laboratory of Advanced Technology for Materials Synthesis and Processing, \\ Wuhan University of Technology, Wuhan 430074, China; habib_aas86@outlook.com \\ 4 Environment and Sustainability Institute, University of Exeter, Penryn TR10 9FE, Cornwall, UK; \\ A.Tahir@exeter.ac.uk \\ 5 Department of Chemistry, Abdul Wali Khan University, Mardan 23200, KP, Pakistan \\ * Correspondence: abbas053@gmail.com (A.K.); hu203@exeter.ac.uk (H.U.)
}

check for updates

Citation: Usman, M.; Humayun, M.; Shah, S.S.; Ullah, H.; Tahir, A.A; Khan, A.; Ullah, H. Bismuth-Graphene Nanohybrids: Synthesis, Reaction Mechanisms, and Photocatalytic Applications-A Review. Energies 2021, 14, 2281. https://doi.org/ $10.3390 /$ en14082281

Academic Editor:

Emmanuel Kymakis

Received: 24 March 2021

Accepted: 14 April 2021

Published: 19 April 2021

Publisher's Note: MDPI stays neutral with regard to jurisdictional claims in published maps and institutional affiliations.

Copyright: (c) 2021 by the authors. Licensee MDPI, Basel, Switzerland. This article is an open access article distributed under the terms and conditions of the Creative Commons Attribution (CC BY) license (https:/ / creativecommons.org/licenses/by/ $4.0 /)$.

\begin{abstract}
Photocatalysis is a classical solution to energy conversion and environmental pollution control problems. In photocatalysis, the development and exploration of new visible light catalysts and their synthesis and modification strategies are crucial. It is also essential to understand the mechanism of these reactions in the various reaction media. Recently, bismuth and graphene's unique geometrical and electronic properties have attracted considerable attention in photocatalysis. This review summarizes bismuth-graphene nanohybrids' synthetic processes with various design considerations, fundamental mechanisms of action, heterogeneous photocatalysis, benefits, and challenges. Some key applications in energy conversion and environmental pollution control are discussed, such as $\mathrm{CO}_{2}$ reduction, water splitting, pollutant degradation, disinfection, and organic transformations. The detailed perspective of bismuth-graphene nanohybrids' applications in various research fields presented herein should be of equal interest to academic and industrial scientists.
\end{abstract}

Keywords: bismuth/graphene; nanohybrids; photocatalysis; reaction mechanisms; energy; pollution

\section{Introduction}

The increase in pollution due to urbanization and industrialization has become a significant challenge for the sustainability of human society. The waste generated in different industries during crude oil storage, transportation, and refinery has become a global problem [1,2]. The water and soil pollution caused by several pollutants' discharge is a critical public health concern due to their toxicity. These pollutants can cause many health effects such as neurological toxicity, lung cancer, lethargy, fatigue, depression, headaches, nausea, dizziness, throat and eye irritation, and acute and chronic respiratory effects [3]. Toluene, benzene, xylene, ethyl benzene, and phenolic compounds some of the main compounds categorized as pollutants posing severe threats to our environment [4-6]. In the present situation, environmental pollution has increased several-fold due to the mismanagement of industrial waste. This can negatively affect the ecosystem and make lands unusable for agriculture and many other purposes [7]. Therefore, it is essential to remediate these toxic pollutants in our environment [8-10].

To eliminate organic pollutants from the environment, numerous technologies have recently been established for their degradation. Organic pollutants can be degraded by different methods, such as physical, chemical, biological treatments and advanced oxidation techniques [9,11-15]. Organic pollutant photodegradation is an attractive "green" chemical 
technology to control pollution, where photocatalysis is the most widely and potentially applied method used for demineralization and degradation of such pollutants $[16,17]$.

Various light sources have been applied for the excitation of heterogeneous catalysts [18], but the photodegradation approach is more economical if sunlight can be used compared to ultraviolet light $[16,19,20]$. The evolution of the term "photocatalysis" shows the development of certain fundamental concepts of photochemistry. The point where photochemistry became a discipline was when it became differentiated from thermal chemistry. Indeed, several researchers saw irradiation as one of the many methods available to catalyze a response that makes it quicker by, for example, heating or processing it with certain chemicals until the beginning of the 20th century [21]. Ciamician, the first scientist to systematically understand the chemical effect of light, took great pains in finding out if he had "initiated heat" alone rather than "light" [22]. This was appropriately allotted the term "photochemical," whilst the word "photocatalytic" applied to reactions caused by light, but with the same result as thermal reactions. Another step further was the identification of electronically excited states, which became a general idea in 1914 and were part of Bodenstein's photochemical reactions along with reactivity and thermodynamics. In an early stage, more distinction was made in the thermochemistry of the process itself. This allowed for photosynthesis to occur when part of photon energy in the products rose [22,23].

Around $43 \%$ of visible-light energy is solar, so visible-light catalysts are chosen in photoelectrocatalysis and photocatalysis processes. Until now, several semiconductive products have been utilized, including metal oxides $\left(\mathrm{Ag}_{2} \mathrm{O}, \mathrm{TiO}_{2}, \mathrm{Cu}_{2} \mathrm{O}, \mathrm{ZnO}, \mathrm{Fe}_{2} \mathrm{O}_{3}\right.$, $\left.\mathrm{Ta}_{2} \mathrm{O}_{5}\right)$, metal selenides (CdSe and MOSe 2 ), metal phosphides $\left(\mathrm{Ni}_{2} \mathrm{P}\right)$, metal sulfides $\left(\mathrm{Bi}_{2} \mathrm{~S}_{3}\right.$, $\mathrm{ZnS}, \mathrm{MoS}_{2}$, and $\left.\mathrm{CdS}\right)$, multi-structure oxides $\left(\mathrm{Sr} \mathrm{TiO}{ }_{3} \mathrm{WO}\right)$, metal halides and oxyhalides $(\mathrm{AgBr}, \mathrm{BiOBr})$ and metal-free materials $\left(\mathrm{SiC}, \mathrm{Si}\right.$ and $\left.\mathrm{g}-\mathrm{C}_{3} \mathrm{~N}_{4}\right)$, [24-28]. Those with a bandgap (Eg) greater than $3 \mathrm{eV}$, e.g., $\mathrm{SrTiO}_{3}, \mathrm{TiO}_{2}, \mathrm{ZnO}, \mathrm{KTaO}_{3}, \mathrm{ZnS}$, and $\mathrm{SrTiO}_{3}$, are called widebandgap photocatalysts, whereas catalysts with an $\mathrm{Eg}$ of less than $4 \mathrm{eV}$, e.g., $\mathrm{Si}, \mathrm{SiC}, \mathrm{Ag}_{2} \mathrm{O}$, $\mathrm{Bi}_{2} \mathrm{WO}_{6}, \mathrm{CdSe}, \mathrm{InTaO}_{4}, \mathrm{Ag}_{3} \mathrm{VO}_{4}, \mathrm{CoO}, \mathrm{Fe}_{2} \mathrm{O}_{3}, \mathrm{Cu}_{2} \mathrm{O}, \mathrm{TaON}, \mathrm{Ta}_{3} \mathrm{~N}_{5}, \mathrm{CdS}, \mathrm{Bi}_{2} \mathrm{~S}_{3}, \mathrm{~g}-\mathrm{C}_{3} \mathrm{~N}_{4}$, and $\mathrm{BiVO}_{4}$, are photocatalysts that react to visible light [25,29].

Heterogeneous catalysts play a vital role in environmental pollution control [30-32]. Powdered semiconductor photocatalysts are commonly used in various areas, such as carbon reduction [33], selective organic transformations, environmental remediation [34], and water splitting [35]. There has been, in numerous applications, a growing interest in the use of semiconductors as photocatalysts. In 2015, around 5500 documents about photocatalytic applications were published, indicating that interest in heterogeneous photocatalysis was enormous and highly important in diverse research fields. This number has recently grown to over 13,000. A country-specific view of the increase in the number of publications on "photocatalytic degradation" is listed in Table 1. No commercially accessible material can currently meet all application requirements, such as cost-effectiveness, stability, high visible-light quantum efficiency, and security [36]. For such tasks to be completed, a highly effective architecture and system for environmental remediation and energy supply are needed to examine new visible-light semiconductor materials.

The development of nanomaterials has progressed from the synthesis of singleparticles to multicomponent assemblies or hierarchical structures, where two or more pre-synthesized nanomaterials are coupled to obtain multifunctionality. Such multicomponent assemblies are termed nanohybrids. The development and use of these nanohybrids requires interdisciplinary knowledge from the energy and environmental sectors, including the applications reported in references [37-43]. There are previously published review articles on some types and uses of nanohybrids, including gold-graphene oxide nanohybrids [39], organic/inorganic nanohybrids [44], polymer nanohybrids for oil recovery [45], nanohybrids of epoxy/polyamide with carbon nanotubes [46], protein-inorganic nanohybrids [47], gold-based inorganic nanohybrids [48] and polymer-inorganic supramolecular nanohybrids [49]. 
Table 1. Country-wise publications growth on the photocatalytic degradation of organic pollutants. (Data acquired from SciFinder).

\begin{tabular}{ccc}
\hline S. No. & Country & No. of Publications \\
\hline 1 & China & 8838 \\
2 & India & 1090 \\
3 & Iran & 676 \\
4 & South Korea & 384 \\
5 & United States of America & 178 \\
6 & Japan & 175 \\
7 & Malaysia & 158 \\
8 & Saudi Arabia & 103 \\
9 & Pakistan & 84 \\
10 & Italy & 77 \\
11 & Australia & 73 \\
12 & Spain & 72 \\
13 & Brazil & 57 \\
14 & United Kingdom & 48 \\
\hline
\end{tabular}

Graphene is the basic structure of all other carbon allotropes. It is well noted that the potential applications of graphene its derivatives are mainly driven by progressive production of different graphene materials such as graphene oxide (GO), reduced graphene oxide $(\mathrm{rGO})$, functionalized graphene oxide (fGO), and functionalized reduced graphene oxide (frGO) with specific attention to precise applications and this is expected to continue for at least a couple of decades as promising applications and requirements are disclosed [50,51]. Various literature reports on the synthesis, modification and application of photocatalysts based on graphene for energy and environment solutions have already been published [52]. Graphene, graphene and its derivatives [53,54], graphene in photocatalysis [55], graphene doping [56], graphene and graphene oxide sponge [57], nitrogen-doped graphene [58], structure of graphene and its disorders [59], strain engineering of graphene [60], mechanics of graphene nanocomposites [61], chemical vapor deposition of graphene [62], functional modification of graphene/graphene oxide [63], graphene-based fibers [64], and graphene-based electrochemical micro-supercapacitors [65] are some of the subjects that have been reviewed.

Considering the stability, reactivity, reusability, and light-responsive effect of bismuth (Bi) it has been widely used as a photocatalyst. Several state-of-the-art review articles on topics including barium potassium bismuth oxide [66], bismuth-based composite oxides [67], bismuth ferrite nanoparticles [68], bismuth vanadate-based materials [69], bismuth tungstate photocatalysts [70], and bismuth oxyhalides [71] have been published. Annual numbers of publications on graphene photocatalysts in the last ten years are shown in Figure 1a. Similarly, bismuth-containing compounds are significant photocatalysts that react to visible light and fascinating research has been published in the field of bismuth photocatalysis over the last ten years (Figure 1b).

This review, therefore, summarizes and discusses recent Bi-graphene photocatalysts and their energy and environmental sector applications. The choice of bismuth with graphene is due to the vast available literature, as shown in Figure 1. Furthermore, most bismuth-based photocatalysts are stable, reusable, photoactive, cheaper, and more environmentally friendly that other alternatives. Besides, due to some shortcomings of the pristine photocatalysts, such as charge carrier recombination, slow migration of charge carriers, and low visible light absorption [72,73], we discuss modification of graphene with bismuth species to produce improved photocatalysts for practical applications.

The discussion above highlights the vital roles of graphene, bismuth, and nanohybrids. Structural, chemical synthesis and mechanistic aspects of these nanohybrids are discussed, as are the suggested industrial applications of Bi-graphene. Recent literature on energy conversion, degradation of various pollutants, and the $\mathrm{CO}_{2}$ conversion process has been 
overviewed. Finally, the challenges associated with bismuth and graphene and possible solutions have been discussed.
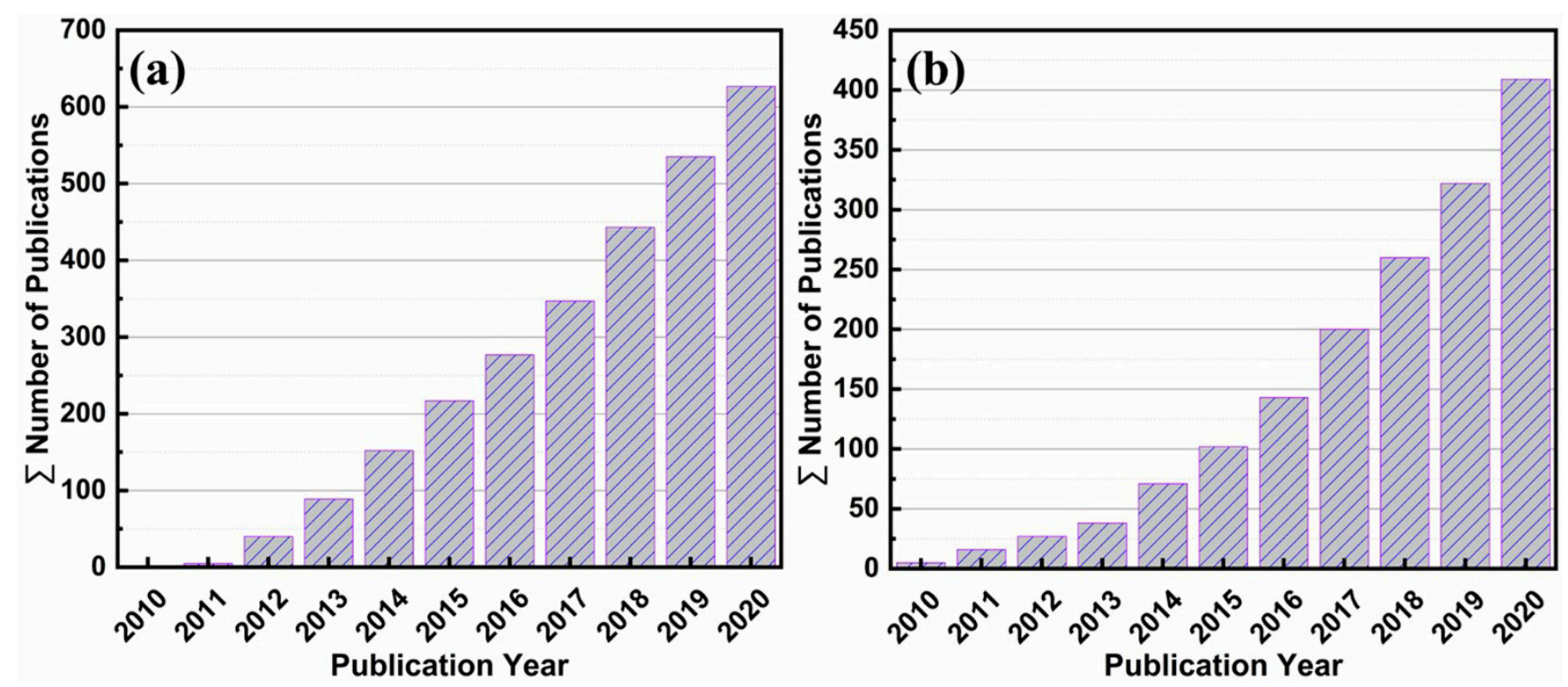

Figure 1. Annual numbers of published items in the last 10 years identified in SciFinder using the keywords: "Graphene-based photocatalysts" (a) and "Bismuth-based photocatalysts" (b).

\section{Bismuth-Graphene Based Photocatalytic Materials}

\section{1. $\mathrm{Bi}_{2} \mathrm{O}_{3}$ and $\mathrm{Bi}_{2} \mathrm{~S}_{3} /$ Graphene Composites}

A significant and the simplest bismuth compound is bismuth trioxide $\left(\mathrm{Bi}_{2} \mathrm{O}_{3}\right)$. It can be used in various ceramics, fuel cells, and gas sensors [74,75]. It has also been used as a photocatalyst in organic pollutant decomposition and water splitting [76]. $\mathrm{Bi}_{2} \mathrm{O}_{3}$ is a visible-light-responding photocatalyst when acting as a semiconductor, and its bandgap ranges between $2.1 \mathrm{eV}$ and $2.8 \mathrm{eV}$. Doping with noble materials and combination with other components have been used to increase graphene's activity in photocatalytic (PC) form $[77,78]$.

In recent times, the $\mathrm{PC}$ activity of some Bi-based semiconductors, e.g., $\mathrm{BiVO}_{4}$ [79], $\mathrm{Bi}_{2} \mathrm{MoO}_{6}$ [80,81], $\mathrm{BiOX}(\mathrm{X}=\mathrm{Cl}, \mathrm{Br}, \mathrm{I}), \mathrm{Bi}_{2} \mathrm{Sn}_{2} \mathrm{O}_{7}$ [82], $\mathrm{Bi}_{2} \mathrm{O}_{3}$ [83], and $\mathrm{BiSbO}_{4}$ [84] in the degradation of pollutants has been described. Bismuth oxide was shown to be a strong candidate among the various Bi-based semiconductors because of its good PC and appropriate bandgap properties. $\mathrm{Bi}_{2} \mathrm{O}_{3}$ 's $\mathrm{PC}$ activity is however restricted by quick recombination of the photogenerated carriers and by its susceptibility to photocorrosion. Because of the short distance between the conduction band $(\mathrm{CB})$ of $\mathrm{Bi}_{2} \mathrm{O}_{3}$ and the valence band (VB), graphene can be designed for the sharing of $\mathrm{Bi}_{2} \mathrm{O}_{3}$ and graphene [85]. Under such conditions, electrons generated in the $\mathrm{CB}$ of $\mathrm{Bi}_{2} \mathrm{O}_{3}$ would quickly be coupled with graphene $\mathrm{VB}$ holes [86]. Therefore, the photogenerated electrons accumulated on the $\mathrm{CB}$ of graphene display strong reduction ability, and the photogenerated holes on the $\mathrm{VB}$ of $\mathrm{Bi}_{2} \mathrm{O}_{3}$, exhibit excellent oxidation ability $[87,88]$. The Z-Scheme PC activities are more effective than one component in terms of reduction and oxidation and advanced photocatalytic performance in the traditional photocatalysts [89,90]. Cui has reported a novel Z-scheme $\mathrm{Bi}_{2} \mathrm{O}_{3}$ /graphene photocatalyst. $\mathrm{Bi}_{2} \mathrm{~S}_{3}$ has a $1.7 \mathrm{eV}$ bandgap and is a perfect photocatalytic material for light-harvesting due to its near-IR and visible light activation [91]. A number of $\mathrm{Bi}_{2} \mathrm{~S}_{3}$ nanocrystal forms ranging from 1D nanorods and 2D nanosheets have been created with hot injection and standard non-oxidation techniques [92,93], while a solvothermal method produces 3D sea-urchin-like spheres [94].

Bismuth sulfide $\left(\mathrm{Bi}_{2} \mathrm{~S}_{3}\right)$ is a priviledged nontoxic inorganic semiconductor with excellent photocatalytic activity and chemical stability because of its good visible light response. It has been exploited and investigated mostly for optoelectronic applications. The photogen- 
erated holes and hydroxyl radicals $(-\mathrm{OH})$ in the $\mathrm{VB}$ of $\mathrm{Bi}_{2} \mathrm{~S}_{3}(1.62 \mathrm{eV})$ are mostly utilized in dye pollutant decomposition [92]. In combination with many other photocatalysts such as $\mathrm{CdS}$ [95], $\mathrm{TiO}_{2}$ [28,96], and $\mathrm{Bi}_{2} \mathrm{WO}_{6}$ [97], the recombination rate of electron-hole pairs could be lowered. An increase in visible light absorption enhances the photocatalytic activity.

A graphene $/ \mathrm{Bi}_{2} \mathrm{~S}_{3}$ nanocomposite with narrow bandwidth was recently synthesized. Compared with the individual components, the PC of this nanocomposite was much higher. Zhou et al. stated that the well-matched bandgap of graphene/ $\mathrm{Bi}_{2} \mathrm{~S}_{3}$ heterojunction could be tailored to increase the transfer and separation efficiency of photoinduced carriers and the visible light response. These graphene $/ \mathrm{Bi}_{2} \mathrm{~S}_{3}$ composites are effective photocatalysts for the photocatalytic degradation of environmental pollutants [74].

\section{2. $\mathrm{Bi}_{2} \mathrm{MO}_{6}(\mathrm{M}=\mathrm{Cr}, \mathrm{Mo}, \mathrm{W}) /$ Graphene Composites}

$\mathrm{Bi}_{2} \mathrm{MO}_{6}(\mathrm{M}=\mathrm{Mo}, \mathrm{Cr}, \mathrm{W})$ is considered the most common member of the Aurivillius family, $\mathrm{Bi}_{2} \mathrm{~A}_{\mathrm{n}-1} \mathrm{~B}_{\mathrm{n}} \mathrm{O}_{\mathrm{n}+3}(\mathrm{~A}=\mathrm{Sr}, \mathrm{Ca}, \mathrm{Ba}, \mathrm{Bi}, \mathrm{Pb}, \mathrm{K}, \mathrm{Na} ; \mathrm{B}=\mathrm{Nb}, \mathrm{Ti}, \mathrm{Ta}, \mathrm{Fe}, \mathrm{W}, \mathrm{Mo})$ is the general formula for $\mathrm{Bi}_{2} \mathrm{MO}_{6}$. The $\mathrm{Bi}_{2} \mathrm{MO}_{6}$ electronic structure is theoretically based on density functional theory (DFT) [98], while the $\mathrm{Bi}_{2} \mathrm{MO}_{6}$ crystal structure falls under orthorhombic space group Pca2(1). It was seen that both VB and $C B$ of $\mathrm{Bi}_{2} \mathrm{MO}_{6}$ are composed of hybridized orbitals $\mathrm{Bi}_{6} \mathrm{p}, \mathrm{O}_{2} \mathrm{p}$, and $\mathrm{M}_{\mathrm{n}} \mathrm{d}\left(\mathrm{n}=3,4\right.$, and 5) for $\mathrm{Bi}_{2} \mathrm{CrO}_{6}, \mathrm{Bi}_{2} \mathrm{MoO}_{6}$, and $\mathrm{Bi}_{2} \mathrm{MO}_{6}$, respectively [99]. $\mathrm{Bi}_{2} \mathrm{MO}_{6}$ compounds are suitable as visible-light-activated photocatalysts. Among all $\mathrm{Bi}_{2} \mathrm{MO}_{6}$ species $\mathrm{Bi}_{2} \mathrm{CrO}_{6}$ has a narrower bandgap, thus, it easily undergoes recombination of photogenerated holes and electrons and is thus not considered suitable as a photocatalyst and consequently few $\mathrm{Bi}_{2} \mathrm{CrO}_{6}$ studies are available in the field of photocatalysis. For the preparation of $\mathrm{Bi}_{2} \mathrm{MoO}_{6}$ samples with a wider special surface area, smaller particles, and higher photocatalytic function, the solvothermal and hydrothermal methods are effective. Several $\mathrm{Bi}_{2} \mathrm{MoO}_{6}$ morphologies have been described, including floral hollow spheres (solvothermal process) and nanoplates (hydrothermal method). Moreover, microwave heating was applied to synthesize $\mathrm{Bi}_{2} \mathrm{MoO}_{6}$ samples with high photocatalytic activity in short periods $[100,101]$. Major applications of $\mathrm{Bi}_{2} \mathrm{MO}_{6}$ (and $\mathrm{Bi}_{2} \mathrm{MoO}_{6}$ and $\mathrm{Bi}_{2} \mathrm{WO}_{6}$ ) photocatalysts involve the removal of organic pollutants from polluted air and water. The key pollutants that have been tested in different studies include phenol [102], dyes [103], $\mathrm{CHCl}_{3}$ and $\mathrm{CH}_{3} \mathrm{CHO}$ in wastewater [104], and $\mathrm{NO}$ in air [105]. Microorganisms, e.g., E. coli, were also destroyed by the addition of $\mathrm{Bi}_{2} \mathrm{WO}_{6}$ [106] and $\mathrm{Bi}_{2} \mathrm{MoO}_{6}$ [107] under visible light irradiation.

Current studies reveal the combined effect of plasmonic metals and graphene. The photocatalytic activity of semiconductors, e.g., $\mathrm{TiO}_{2}$ and $\mathrm{ZnO}$, can be efficiently improved by increasing their photo-absorption ability and suppressing photogenerated electron-hole recombination. Compared to $\mathrm{Bi}_{2} \mathrm{MoO}_{6}, \mathrm{Bi}_{2} \mathrm{MoO}_{6}$-graphene binary composites have been developed and show improved photocatalytic performance. Graphene-based nanocomposites display desirable photocatalytic properties that their individual components do not have, therefore, improved $\mathrm{Bi}_{2} \mathrm{MoO}_{6}$ photocatalytic activity resulting from a combination of noble metals and graphene is expected. Bi et al. developed a $\mathrm{rGO}-\mathrm{Bi}_{2} \mathrm{MoO}_{6} / \mathrm{Au}$ composite that displayed high catalytic activity for the photodegradation of rhodamine $\mathrm{B}$ [20]. Wang and Tian reported composites of $\mathrm{GO}-\mathrm{Bi}_{2} \mathrm{MoO}_{6}$ and $\mathrm{rGO}-\mathrm{Bi}_{2} \mathrm{MoO}_{6}[108,109]$. These composites showed advanced phenol and rhodamine $\mathrm{B}$ degradation properties, respectively, compared to $\mathrm{Bi}_{2} \mathrm{MoO}_{6}$ alone [74].

\section{3. $\mathrm{BiVO}_{4} /$ Graphene Nanocomposites}

Bismuth vanadate $\left(\mathrm{BiVO}_{4}\right)$ presents interesting physicochemical properties, including ionic conductivity and ferroelasticity. A theoretical bandgap of $2.047 \mathrm{eV}$ was calculated by DFT for visible-light-driven photocatalysis [110]. Both $\mathrm{O}_{2} \mathrm{p}$ - and $\mathrm{V}_{3} \mathrm{~d}$-orbitals are included in the $\mathrm{BiVO}_{4}$ valence band. There are three forms of $\mathrm{BiVO}_{4}$, namely monoclinic fergusonite, tetragonal zircon, and tetragonal scheelite. Reversible monoclinic fergusonite and tetragonal scheelite phase transitions occur at $255^{\circ} \mathrm{C}$. A wide range of methods have been reported for $\mathrm{BiVO}_{4}$ preparation. Monoclinic $\mathrm{BiVO}_{4}$ is obtained by both high tempera- 
ture melting reactions and by solid-state reactions (SSR) [111]. Tetragonal $\mathrm{BiVO}_{4}$ has been synthesized at room temperature by a precipitation method [112]. The bandgap for the monoclinic form is $2.4 \mathrm{eV}$, while the bandgap for $\mathrm{BiVO}_{4}$ is $2.9 \mathrm{eV}$. This selective monoclinic $\mathrm{BiVO}_{4}$ preparation is advantageous for assembling effective photocatalysts with visible light shifts. There has been a report of an additional method for synthesizing monoclinic and tetragonal $\mathrm{BiVO}_{4}$ crystals in a simple water-based process [113]. A hydrothermal method has been used successfully in recent times for monoclinic $\mathrm{BiVO}_{4}$ preparation [114]. There are numerous advantages to this hydrothermal approach to selectively produce $\mathrm{BiVO}_{4}$ structures, i.e., mild experimental conditions, controllable conditions and simple experimental setups.

Photocatalytic degradation under visible light is commonly used to decompose organic pollutants (e.g., phenol and RhB) [115], and increased removal efficiency has been demonstrated [116]. $\mathrm{BiVO}_{4}$ was also used for the scission of water [117,118]. $\mathrm{BiVO}_{4}$ was shown to be an active photocatalyst for $\mathrm{O}_{2}$ evolution under visible light radiation since its conduction strip potential isn't high enough to produce $\mathrm{H}_{2}$ by $\mathrm{H}_{2} \mathrm{O}$ reduction [119]. Booshehri et al., found $\mathrm{BiVO}_{4}$ to be a mild candidate for photocatalytic inactivation of bacteria in water under visible light irradiation [120]. For photocatalytic bactericidal activity, surface redox reactions are essential for reactive species generation [121]. In addition, the interface for charge separation and transfer in hybrid catalysts is to be considered for two components [122]. The $\mathrm{BiVO}_{4} / \mathrm{Ag} /$ graphene photocatalyst showed improved activity for photocatalytic degradation of organic pollutants [123,124] or oxidation of nitrogen monoxide and water [125]. The probability of photocatalytic wastewater or disinfection of water by the Z-scheme $\mathrm{BiVO}_{4} /$ graphene is however still unknown to the best of our knowledge. Moreover, at the molecular level the photocatalysis consistency is clearly not yet investigated [74].

\section{4. $\operatorname{BiOX}(\mathrm{X}=\mathrm{F}, \mathrm{Cl}, \mathrm{Br}, \mathrm{I}) / \mathrm{Graphene}$ Composites}

Bismuth oxyhalides' (BioXoptical)'s properties can work as a photocatalyst. The structure of $\mathrm{BiOX}$ crystals is comprised of layer structure slabs $\left[\mathrm{Bi}_{2} \mathrm{O}_{2}\right]$ which are inserted in two halogen atoms [126,127]. Biox contain X np ( $\mathrm{n}=2-5$ for $\mathrm{Cl}, \mathrm{F}, \mathrm{I}$, and $\mathrm{Br}$ respectively), $\mathrm{O} 2 \mathrm{p}$, and $\mathrm{Bi} 6 \mathrm{p}$-orbitals both in the valence band (VB) and conduction band (CB). In theoretical terms, the bandgaps of $\mathrm{BiOI}, \mathrm{BiOF}, \mathrm{BiOBr}$, and $\mathrm{BiOCl}$ are calculated to be $1.38 \mathrm{eV}$, $2.79 \mathrm{eV}, 1.99 \mathrm{eV}$, or $2.34 \mathrm{eV}$, while experimentally, their bandgaps are estimated to be $1.77 \mathrm{eV}, 3.64 \mathrm{eV}$ [128], $2.64 \mathrm{eV}$, and $3.22 \mathrm{eV}$ [129]. There are restrictions within the GGA method that cause these differences between the experimental and calculated bandgap results. However, both indicate the general decreasing tendency of the bandgaps as the atomic number increases. BIOF was used as a photocatalyst only under UV light, while BiOI was photocatalytically active both under near-IR and visible light. Because of their appropriate bandgaps, both $\mathrm{BiOCl}$ and $\mathrm{BiOBr}$ are therefore commonly tested. For $\mathrm{BiOX}$ synthesis with different morphologies, several methods can be effectively applied. In addition to direct precipitation techniques, the primary methods used to synthesize the BiOX with controlled nanostructures such as nanosheets, microsphere, and nanofibers include hydrolysis, solvothermal and hydrothermal methods [130]. By adjusting the precursor $\mathrm{pH}$, controlling hydrothermal treatment duration time and temperature, and by adding a template structure that can be selectively controlled, one can directly affect the photocatalytic performance. An extensive review of BiOX nanostructures was previously published [131].

Significant efforts have been carried out to design innovative photocatalysts [132,133]. Because of their excellent catalytic activity under visible light, the sequence of ternary bismuth oxyhalides ( $\mathrm{BiOX}, \mathrm{X}=\mathrm{Cl}, \mathrm{Br}$, or I) has been commonly studied [134]. The charge separation and atomic polarization efficiency of the layered BiOX structures can be improved. $\mathrm{BiOBr}$, with its crystalline $\mathrm{PbFCl}$ layer structure has been a big consideration among $\mathrm{BiOX}$ photocatalysts because of its excellent photocatalytic activity, appropriate bandgap, and high stability. The binary component and multi-component counterparts 
showed improved photocatalytic activity compared to single-component semiconductors. Multi-component synergies may overcome the single-component shortcomings, e.g., insufficient charge separation ability and wide-bandgap. Consequently, the BiOBr photocatalytic activity $[135,136]$ with an indirect-transition bandgap $(2.75 \mathrm{eV})$ may be efficiently enhanced by incorporating other materials.

Graphenes are currently used as a promising support platform for anchoring host NPs as well as acceptors for charge separation and superb electron transfer mediation with peculiar characteristics such as low density, high conductivity, and large surface areas [137-139]. The hydrothermal method has been used for the synthesis of $\mathrm{Au} / \mathrm{BiOBr} /$ graphene composites [140,141].

A practical approach to shrink the bandgap, increase the catalytic activity and visiblelight absorption was taken using black BiOCl material with the formation of oxygen vacancies. Although the black $\mathrm{BiOCl}$ is still subject to recombination of fast photocatalytic charge carriers, its photocatalytic activity is still not satisfactory. A simple and effective approach to resolve the above-related problems has been taken as the construction hetero-structures of BiOCls with the other appropriate photocatalysts. Thanks to their high electron mobility and a large surface area, the above issues could be well addressed by functional graphenebased semiconductor photocatalysts. A new BiOCl-Bi- $\mathrm{Bi}_{2} \mathrm{O}_{3} / \mathrm{rGO}$ heterojunction with oxygen vacancies has been developed, which provided a solid-solid, close-fit interface and strong interaction between $\mathrm{BiOCl}, \mathrm{Bi}, \mathrm{rGO}$, and $\mathrm{Bi}_{2} \mathrm{O}_{3}$. $\mathrm{BiOCl}-\mathrm{BI}_{2} \mathrm{O}_{3} / \mathrm{rGO}$ heterojunctions showed high photocatalytic performance due to the synergistic effect caused by effective charge separation among $\mathrm{Bi}_{2} \mathrm{O}_{3}, \mathrm{BiOCl}, \mathrm{rGO}$, and Bi-bridges. The $\mathrm{BiOCl}-\mathrm{Bi}$ $\mathrm{Bi}_{2} \mathrm{O}_{3} / \mathrm{rGO}$ heterojunction displayed high efficiency for photocatalytic degradation of 2-nitrophenol in industrial wastewater treatment. The significant task is to demonstrate the superior long-term photostability of the $\mathrm{BiOCl}-\mathrm{Bi}_{-}-\mathrm{Bi}_{2} \mathrm{O}_{3} / \mathrm{rGO}$ heterojunctions. In addition, a promising $\mathrm{BiOCl}-\mathrm{Bi}-\mathrm{Bi}_{-}-\mathrm{Bi}_{2} \mathrm{O}_{3} / \mathrm{rGO}$ photocatalytic mechanism was proposed to describe primary phenomena taking place during the process, depending on multiple charge transfer channels [141].

\section{5. $\mathrm{BiPO}_{4} /$ Graphene Composites}

$\mathrm{BiPO}_{4}$ with high photocatalytic activity for organic pollutant degradation was fabricated for the first time by a hydrothermal approach [142]. A faster hydrothermal way of synthesizing $\mathrm{BiPO}_{4}$ has also been reported [143]. The bandgap in $\mathrm{BiPO}_{4}$ prepared by hydrothermal methods is about $3.85 \mathrm{eV}$, higher than that of $\mathrm{TiO}_{2}(3.2 \mathrm{eV}) . \mathrm{BiPO}_{4}$ nanocrystals synthesized with standard oxygen-free procedures have a bandwidth of around $4.6 \mathrm{eV}$. Only UV light can be used as a light source for large bandgap semiconductors. Although its bandgap is broader than that of $\mathrm{TiO}_{2}, \mathrm{BiPO}_{4}$ still has high photocatalytic degradation kinetics. This is because the $\mathrm{VB}$ of $\mathrm{BiPO}_{4}$ is $3 \mathrm{eV}$, higher than that of $\mathrm{TiO}_{2}$, and it generates more oxidative holes in its $\mathrm{VB}$ compared to $\mathrm{TiO}_{2}$. Photocatalytic conversion of the gas-phase benzene into $\mathrm{CO}_{2}$ by $\mathrm{BiPO}_{4}$ has also been reported in addition to the degradation of the organic pollutant in an aqueous phase. A photocatalytic gas-phase transformation of benzene to $\mathrm{CO}_{2}$ was also reported during an aqueous phase organic pollutant degradation study $[144,145] . \mathrm{BiPO}_{4}$ photocatalysts still have several drawbacks as photocatalysts however, such as low photocatalytic activity, and comparatively rapid recombination of charge carriers, wide bandgaps, low adsorption ability, and large size, which would decrease the photocatalytic activity of $\mathrm{BiPO}_{4}$ and subsequently limit its industrial-scale applications $[146,147]$. Consequently, it is urgent to create and design photocatalytic materials based on $\mathrm{BiPO}_{4}$, with required and useful photocatalytic performance properties. To date, numerous efforts have been made to improve the photocatalytic activity of the $\mathrm{BiPO}_{4}$ photocatalyst by doping with non-metals or metals, surface hybridization, reducing the crystal size, forming heterostructures, or combinations of $\mu$-structure materials [148,149]. $\mathrm{BiPO}_{4} / \mathrm{rGO}$ nanocomposites exposed the importance of graphene as the support of separating electron-hole pairs, which leads to a high photocurrent. Thus, the development of $\mathrm{BiPO}_{4} / \mathrm{rGO}$ hybrids is an efficient way to improve the visible light catalytic 
performance of $\mathrm{BiPO}_{4}$. Extensive research has established a trend towards research in carbon-nanomaterials by doping with heteroatoms as they can adapt their fundamental properties successfully $[150,151]$.

\section{6. (BiO) ${ }_{2} \mathrm{CO}_{3} /$ Graphene $\mathrm{C}$ omposites}

Bismuth subcarbonate is a known solid carbonate in the $\mathrm{BI}_{2} \mathrm{O}_{3}-\mathrm{CO}_{2}-\mathrm{H}_{2} \mathrm{O}$ system $\left((\mathrm{BiO})_{2} \mathrm{CO}_{3}\right.$ or $\left.\mathrm{Bi}_{2} \mathrm{CO}_{5}\right)$ [152]. The bandgap of $(\mathrm{BiO})_{2} \mathrm{CO}_{3}$ is $3.4 \mathrm{eV}$, so wavelengths under $365 \mathrm{~nm}$ can therefore stimulate the bandgap $[153,154]$. The $\mathrm{CB}$ of $(\mathrm{BiO})_{2} \mathrm{CO}_{3}$ generally includes hybridized p-orbitals $\left(\mathrm{O}_{2} \mathrm{p}\right.$ and $\left.\mathrm{Bi} 6 \mathrm{p}\right)$, while its VB consists of p-orbitals $(\mathrm{O} 2 \mathrm{p}$, Bi $6 p$, and $C 2 p$ ). A hydrothermal, template-free method has been used to efficiently synthesize $(\mathrm{BiO})_{2} \mathrm{CO}_{3}$ with hollow microsphere orders whose structure is dependent on Ostwald's growing properties. The compound showed photocatalytic activity for pollutant oxidation or disinfection of air and wastewater contamination $[155,156]$. Several articles have described $p-n$ heterojunctions that exhibited enhanced photocatalytic activity [74,157].

An innovative multi-component $\mathrm{TiO}_{2}-\mathrm{Bi}_{2} \mathrm{O}_{3} /(\mathrm{BiO})_{2} \mathrm{CO}_{3}-\mathrm{rGO}$ nanocomposite has been synthesized and experimentally used for bisphenol A (BPA) photodegradation. The $\mathrm{Bi}_{2} \mathrm{O}_{3}$ was intended to be a visible light photosensitizer. The appropriate VB and CB's positions $\mathrm{TiO}_{2}$ and $(\mathrm{BiO})_{2} \mathrm{CO}_{3}$ were used as selective sinks for photogenerated holes and electrons, and rGO acted as a channel for charge carrier transport that extended the lifetime of the catalysts. BPA is an endocrine disruptive compound commonly used for the production of many common packaging materials [158]. These materials typically end up in waste dumps, leading to the slow leaching of BPA into water bodies. Accordingly, BPA has been chosen as the model for the photocatalytic activity of the designed photocatalysts based on environmental issues [158,159].

\section{7. $\mathrm{M}\left(\mathrm{BiO}_{3}\right)_{n} /$ Graphene Composites}

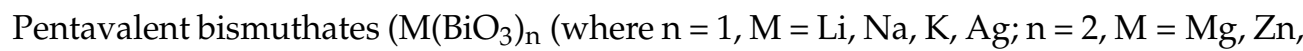
$\mathrm{Sr}, \mathrm{Ba}$, and $\mathrm{Pb}$ ) can be bought directly from commercial companies to synthesize additional Bi-based compounds, such as $\mathrm{BiOX}$, as a Bi source [160]. The bandgaps of these compounds are $\mathrm{MgBi}_{2} \mathrm{O}_{6} 1.61 \mathrm{eV}, \mathrm{ZnBi}_{2} \mathrm{O}_{6} 1.53 \mathrm{eV}, \mathrm{SrBi}_{2} \mathrm{O}_{6} 1.93 \mathrm{eV}, \mathrm{SrBi}_{2} \mathrm{O}_{6} 1.93 \mathrm{eV}, \mathrm{BaBi}_{2} \mathrm{O}_{6} 1.93 \mathrm{eV}$, $\mathrm{PbBi}_{2} \mathrm{O}_{6} 1.92 \mathrm{eV}$ [161], $\mathrm{LiBiO}_{3} 1.8 \mathrm{eV}, \mathrm{KBiO}_{3} 2.1 \mathrm{eV}$ [162], $\mathrm{NaBiO}_{3} 2.6 \mathrm{eV}$ [163], and $\mathrm{AgBiO}_{3}$ $2.5 \mathrm{eV}$, respectively [164]. The valency of Bi-based composites is +3 while the value of $\left(\mathrm{BiO}_{3}\right)_{\mathrm{n}}$ is +5 . The $\mathrm{Bi}^{3+}$ cation consists of two orbitals $(10 \mathrm{~d}$ and $6 \mathrm{~s})$. This indicates that the electronic structure of pentavalent bismuthates is different. Takei et al. tested nine bismuthates for degrading phenol and methylene blue [161]. High photo-catalytical activity under visible light irradiation was shown by $\mathrm{NaBiO}_{3}, \mathrm{LiBiO}_{3}, \mathrm{BaBi}_{2} \mathrm{O}_{6}$, and $\mathrm{SrBi}_{2} \mathrm{O}_{6}$. The d-electrons from $\mathrm{Zn}, \mathrm{Pb}$ and $\mathrm{Ag}$ produce a large conduction range as well as consequently poor photocatalytic performance. Electronic systems greatly affect catalytic performance. Excellent visible-light photocatalytic activity recommends pentavalent bismuthates for different photocatalytic applications. $\mathrm{M}\left(\mathrm{BiO}_{3}\right) \mathrm{n}$ could be used for efficient visible light photocatalytic degradation of organic pollutants [161,165].

\section{Synthesis of Bismuth/Graphene Nanohybrid Materials}

In composites based on bismuth graphene, the graphene acts as a substrate for immobilization and the other composites as a functional component. The robust conductive structure and wide graphene surfaces often facilitate the redox reaction, charge transfer, and the enforcement of the resulting composites' mechanical strengths. The coupling of metal oxides with graphene will therefore enhance the efficiency for numerous energy conversion, storage, and catalytic reactions [166,167]. This section mainly focused on the recent progress to develop practical approaches to fabricate $\mathrm{Bi}$ - graphene nanocomposites.

\subsection{Sol-Gel Method}

In this section, we focus on recent progress in the development of practical approaches for the fabrication of Bi-graphene nanocomposites [168-170]. The robust coupling offers 
many applications for hybrids, such as photocatalysis [171-173]. Anchoring and reactive areas for growth and the nucleation of NPs can be found in functional groups based on reduced graphene oxides $(\mathrm{GO} / \mathrm{rGO})$, which allow metal oxide nanostructures to be chemically attached to GO/RGO surfaces.

A new sol gel-based electro-spinning process configuration was adopted for the fabrication of $\mathrm{TiO}_{2} / \mathrm{ZnO} / \mathrm{Bi}_{2} \mathrm{O}_{3}-\mathrm{Gr}$ (TZB-Gr) composites photocatalyst. With this technique, the rim effect was removed by rolling graphene into 'spiral rolls' implanted in $\mathrm{TiO}_{2} / \mathrm{ZnO} / \mathrm{Bi}_{2} \mathrm{O}_{3}$ (TZB) nanofibers, which allowed free electrons to move in the axis of nanofibers on the graphene rolls unidirectional [174]. This new configuration significantly reduced the energy bandgap, enhanced the specific surface area, accelerated charge transport and delayed electron-hole pair recombination. In this unique configuration, the electrons' mobility and lifetime were enhanced [175]. The scheme of TZB-Gr nanofibers is shown in Figure 2.

\section{TZB-Gr Nanofiber}

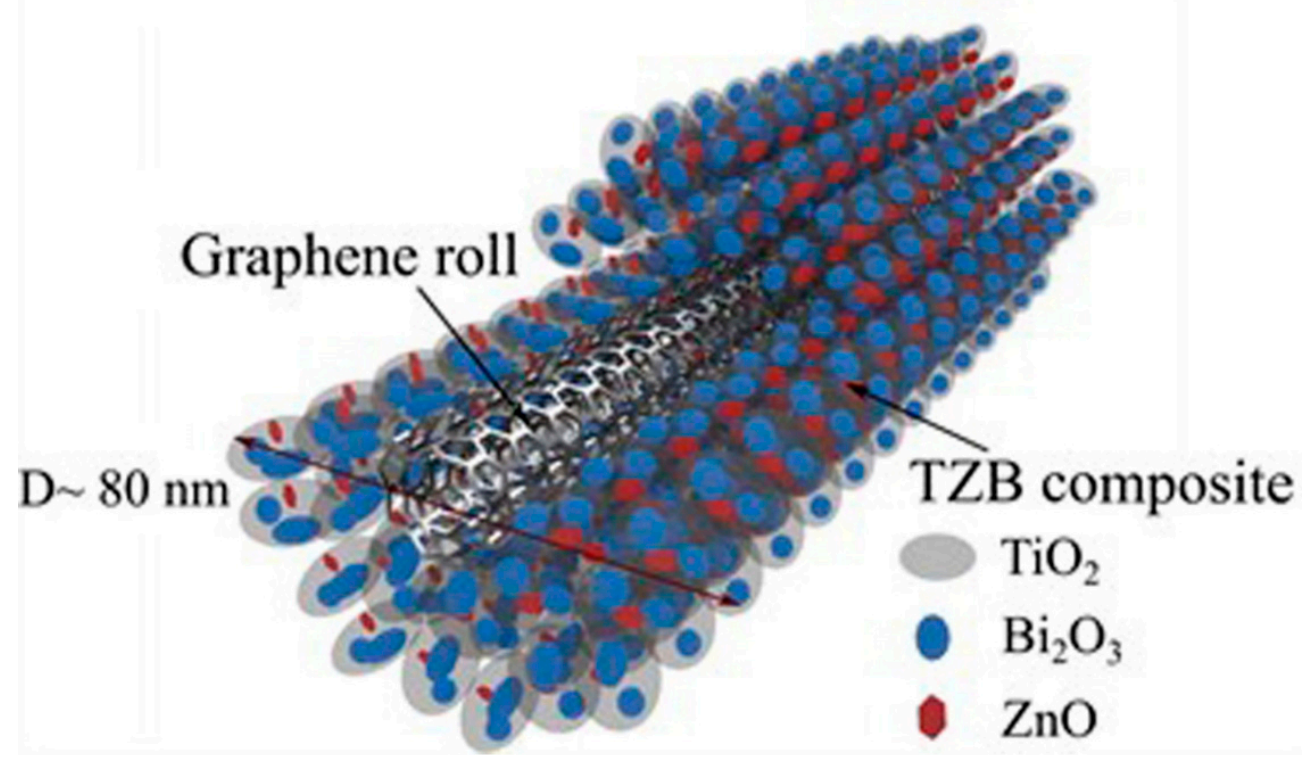

Figure 2. Schematic representation for $\mathrm{TiO}_{2} \mathrm{NPs}$ deposition on graphene sheets; as-prepared $\mathrm{TiO}_{2} / \mathrm{ZnO} / \mathrm{Bi}_{2} \mathrm{O}_{3}$-graphene (TZB-Gr) nanofibers. Adapted from [175].

\subsection{Hydrothermal/Solvothermal Methods}

Hydrothermal/solvothermal methods are key tools for synthesizing inorganic nanocrystals that work at a high temperature in a limited volume under high pressure. With a one-pot hydrothermal/solvothermal approach, highly crystalline nanostructures can be prepared without post-synthetic calcination, and at the same time GO is reduced to rGO. The rational design of nanomaterials and fabrication with distinctive morphology has received a great deal of consideration because the material properties depend not only on the chemical phase and its composition, but also on its size and shape. The synthesis of nanomaterials with different sizes has inspired many researchers due to its potential applications and the size-dependent properties [176]. Consequently, numerous approaches have been developed to make nanocrystals with controlled morphology. Among them, the hydrothermal method is considered to be effective because it is useful for controlling the size and shape of nanomaterials [177]. $\mathrm{rGO} / \mathrm{Bi}_{2} \mathrm{MoO}_{6}$ nanocomposites are effectively synthesized via a simple hydrothermal process, with virtual uniformity and high-order direction. The rGO had also been added to the surface of $\mathrm{Bi}_{2} \mathrm{MoO}_{6}$. There is an extraordinary improvement in the photocatalytic activity for bacterial treatment over the $\mathrm{Bi}_{2} \mathrm{MoO}_{6}-\mathrm{rGO}$ nanocomposite compared to the pure $\mathrm{Bi}_{2} \mathrm{MoO}_{6}$. This enhancement is accredited to the high orientation of $\mathrm{Bi}_{2} \mathrm{MoO}_{6}$, which efficiently improved photogenerated electrons-holes pair's separation. 
At the generation site, these electrons are quickly inserted into graphene, thus reducing charge recombination. Improved visible light catalytic wastewater treatment performance of $\mathrm{Bi}_{2} \mathrm{MoO}_{6}-\mathrm{rGO}$ nanocomposites can be accomplished [107].

The $\mathrm{Bi}_{2} \mathrm{MoO}_{6}$ microsphere surface contains different sizes of $\mathrm{Ag}_{3} \mathrm{PO}_{4}$ particles. The $\mathrm{Bi}_{2} \mathrm{MoO}_{6}$ and $\mathrm{Ag}_{3} \mathrm{PO}_{4}$ microspheres on both sides of the layer $\mathrm{rGO}$ are also well connected. The $\mathrm{Ag}_{3} \mathrm{PO}_{4} / \mathrm{rGO} / \mathrm{Bi}_{2} \mathrm{MoO}_{6}$ structure can be established with a closed interface, which is beneficial during the photocatalytic process to accelerate charge transfer. The appropriate porous structures and storage surface can offer substantial active surface sites to easily absorb more organic pollutants, which would favor an increase in the photocatalytic activity of the $\mathrm{Ag}_{3} \mathrm{PO}_{4} / \mathrm{rGO} / \mathrm{Bi}_{2} \mathrm{MoO}_{6}$ composite [178]. $\mathrm{Ag}_{3} \mathrm{PO}_{4} / \mathrm{rGO} / \mathrm{Bi}_{2} \mathrm{MoO}_{6}$ shows the broadest absorption edge and the highest absorption intensity in the visible light region. This suggests that this ternary composite can absorb a broad spectrum of visible light [179]. Figure 3 describes the synthesis process for $\mathrm{Ag}_{3} \mathrm{PO}_{4} / \mathrm{rGO} / \mathrm{Bi}_{2} \mathrm{MoO}_{6}$ nanohybrid, a photocatalytic mechanism for MB-degradation via $\mathrm{Ag}_{3} \mathrm{PO}_{4} / \mathrm{rGO} / \mathrm{Bi}_{2} \mathrm{MoO}_{6}$ nanohybrid, and energy band structures of $\mathrm{Ag}_{3} \mathrm{PO}_{4}$ and $\mathrm{Bi}_{2} \mathrm{MoO}_{6}$.

(a)

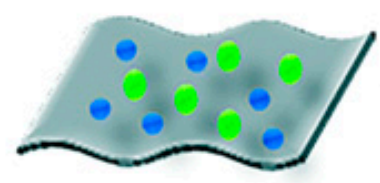

$\mathrm{Ag}_{3} \mathrm{PO}_{4} / \mathrm{RGO} / \mathrm{Bi}_{2} \mathrm{MoO}_{6}$

(b)

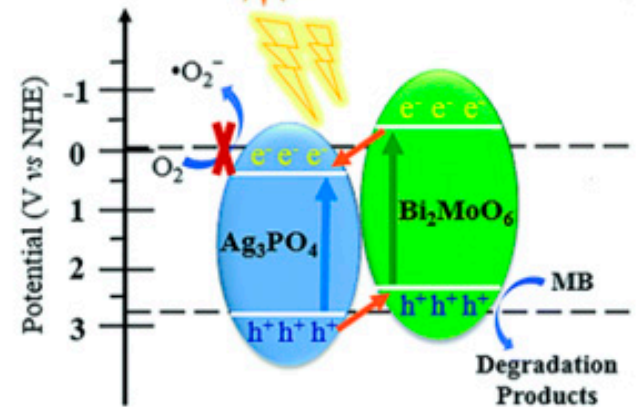

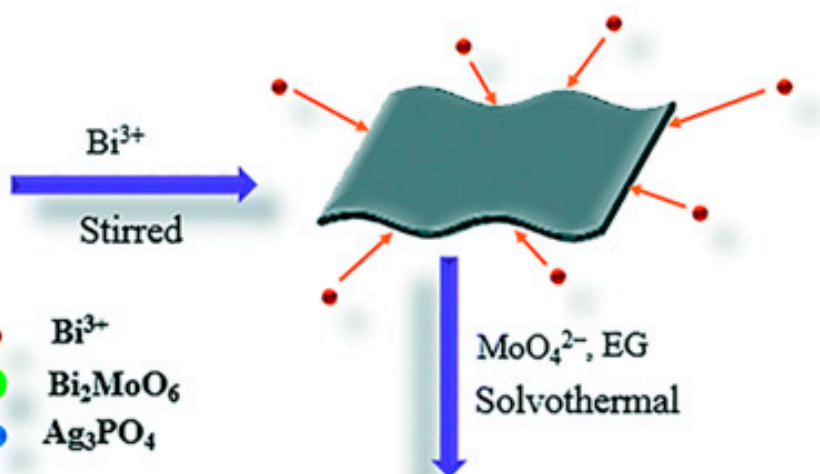

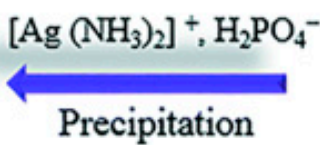

Precipitation

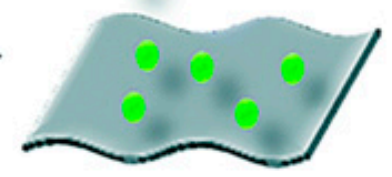

$\mathrm{Bi}_{2} \mathrm{MoO}_{6} / \mathrm{RGO}$
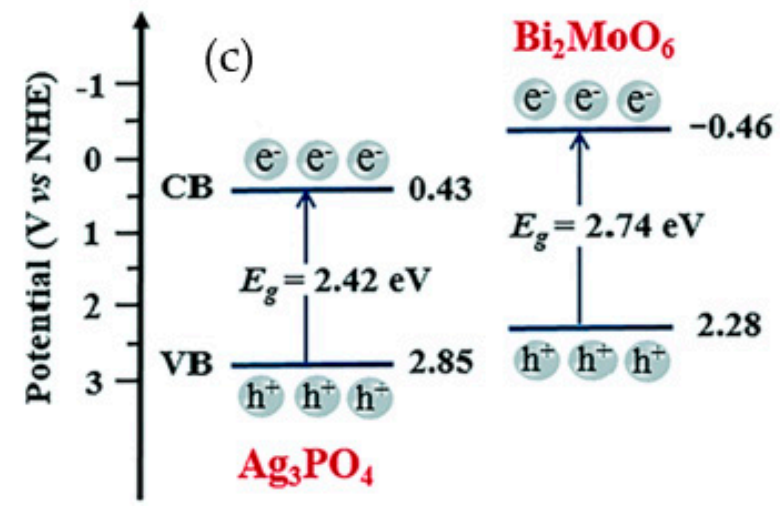

Figure 3. (a) Synthesis process for $\mathrm{Ag}_{3} \mathrm{PO}_{4} / \mathrm{RGO} / \mathrm{Bi}_{2} \mathrm{MoO}_{6}$ nanohybrid, (b) $\mathrm{MB}$-photocatalytic mechanism via an $\mathrm{Ag}_{3} \mathrm{PO}_{4} / \mathrm{RGO} / \mathrm{Bi}_{2} \mathrm{MoO}_{6}$ nanohybrid, and (c) energy band structures of $\mathrm{Ag}_{3} \mathrm{PO}_{4}$ and $\mathrm{Bi}_{2} \mathrm{MoO}_{6}$. Source: Adapted from [178].

For $\mathrm{BiPO}_{4}$ and graphene composite formation, two approaches are used. Because two-dimensional high-surface graphene platforms and exceptionally high conductivity can properly contact the target pollutants to provide plenty of reactive sites and efficiently accelerate the process of transferring photo-induced electrons from photocatalyst to reactant sites to suppress the photo-induced pair of electron-holes, graphene and nanocomposite integration with the appropriate graphene and $\mathrm{BiPO}_{4}$ may have desirable graphene and 
$\mathrm{BiPO}_{4}$ properties. This will significantly improve the photocatalytic activity of the $\mathrm{BiPO}_{4}$ system. The two-step method of preparing the $\mathrm{BiPO}_{4} / \mathrm{GO}$ nanocomposites was first used to synthesize oleylamine-coated $\mathrm{BiPO}_{4}$ and then assemble it onto a GO nanosheet at the water/toluene interface in the second step [180,181].

A two-step hydrothermal approach was used to synthesize $\mathrm{BiPO}_{4} / \mathrm{rGO}$ cuboids with low $\mathrm{OH}$-related defects. Although nanocomposites are produced successfully with $\mathrm{BiPO}_{4}-\mathrm{GO}$ or $\mathrm{BiPO}_{4} / \mathrm{rGO}$, the experiments still display a large number of inconveniences: (1) $\mathrm{BiPO}_{4} / \mathrm{GO}$ or $\mathrm{BiPO}_{4}-\mathrm{rGO}$ nanocomposite synthesis requires two or several steps that are tedious and time-consuming; (2) toxic organic solvents (toluene), hazardous reducing agents (oleylamine) and other additives may cause many environmental protection problems and in the product post-treatment; (3) the weak interaction between graphene nanosheets and $\mathrm{BiPO}_{4}$ results from 2- or multi-step synthetic routes to $\mathrm{BiPO}_{4} / \mathrm{rGO}$, so a simple, efficient, and green approach has been used to synthesize nanocomposites.

The full GO reduction to graphene, the formation of $\mathrm{BiPO}_{4}$-nanorods, and appropriate mixing are carried out in a one-stage synthetic route using these two materials. As an essential agent for GO reduction, ethylene glycol (EG) plays an important role and does not require any additional agents. Besides, ethylene glycol is compatible with $\mathrm{BiPO}_{4}$ nanorod preparation. $\mathrm{BiPO}_{4}-2 \% \mathrm{rGO}$ is far more photocatalytic than pure $\mathrm{BiPO}_{4}$, and graphene for photodegradation of methyl orange under UV radiation is accredited to a wider surface area, efficient cargo transportation, the graphene introduction, and the close interfacial contact between graphene and $\mathrm{BiPO}_{4}$ have contributed to a much-increased adsorption and separation capacity $[182,183]$. $\mathrm{BiPO}_{4} / \mathrm{rGO}$ and $\mathrm{BiPO}_{4} / \mathrm{GO}$ composites synthesized, and simulated images are shown in Figure 4.

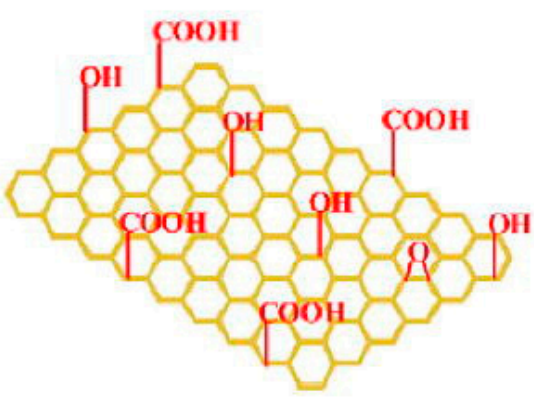

GO

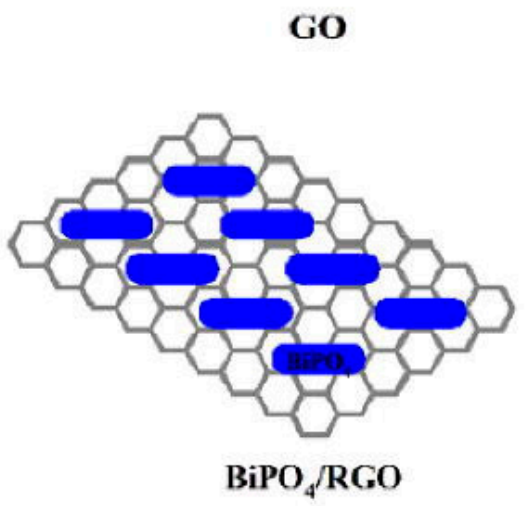

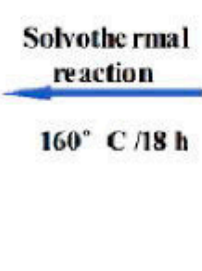
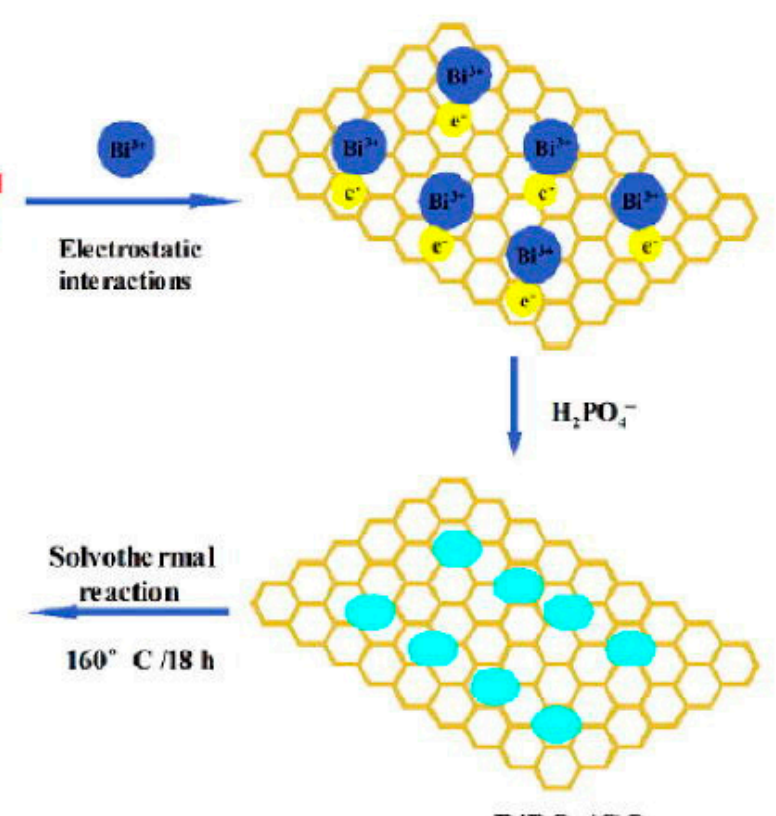

$\mathrm{BiPO}_{4} / \mathrm{GO}$

Figure 4. Synthesis process for $\mathrm{BiPO}_{4} / \mathrm{RGO}$ and $\mathrm{BiPO}_{4} / \mathrm{GO}$ composites. Source: Adapted from [183].

A simple one-pot hydrothermal route was used to synthesize nanocomposites of $\mathrm{biPO}_{4} /$ nitrogen-doped graphene hydrogel $\left(\mathrm{BiPO}_{4}\right)$ to serve as a visible light-responsive material. The porous 3DNGH structure significantly enhanced the photo-induced electron holes and the transfer and separation efficiency of $\mathrm{BiPO}_{4}$ visible illumination pairs. The $\mathrm{BiPO}_{4} / 3 \mathrm{DNGH}$ morphology has disclosed a cross-linked, porous structure, and 3DNGH nanorods are attached to the area. The 3DNGH surface was randomly dispersed with $\mathrm{BiPO}_{4}$ nanorods [181]. 
$\mathrm{A} \mathrm{BiPO}_{4} \mathrm{NPs}_{\mathrm{s}}$ with $\mathrm{MoS}_{2}$ /graphene-layered hybrid is manufactured via an easy hydrothermal, microwave-assisted method, and the ternary $\mathrm{BiPO}_{4}-\mathrm{MoS}_{2} /$ graphene photocatalyst optimizes the activity of each component. This study demonstrates that the graphene and $\mathrm{MoS}_{2}$ nanoparticles as catalysts in the photocatalyst of $\mathrm{BiPO}_{4}$ can improve transport charges, eliminate the pair electron hole's photogenerated recombination rate, and provide highly reactive locations for a photodegradation reaction. This results in significantly improved photocatalytic activity for organic pollutant photodegradation by the attained $\mathrm{BiPO}_{4}-\mathrm{MoS}_{2}$ /graphene photocatalyst. The $\mathrm{GO}, \mathrm{BiPO}_{4}$, and $\mathrm{MoS}_{2}$ composite microstructure and morphology were characterized in the sense that $\mathrm{GO}$ has a layered stacking structure with some folds and wrinkles that can adsorb and photodegrade the color molecules on sufficiently large surfaces. The sample produced for $\mathrm{MoS}_{2}$ has an ultra-free nanosheet structure. In composites many $\mathrm{BiPO}_{4} \mathrm{NPs}$ are dispersed compactly and homogenously on the surface of $\mathrm{MoS}_{2}$ /graphene nanosheets. It is proposed to dispense, build, and attach the $\mathrm{BiPO}_{4}$ nanocrystals in $\mathrm{MoS}_{2} /$ graphene by microwave-assisted techniques. There are distinct gate fringes on the $\mathrm{BiPO}_{4}-\mathrm{MoS}_{2} /$ graphene composite. The gap from $0.328 \mathrm{~nm}$ to the monoclinic plane $\mathrm{BiPO}_{4}(200)$ corresponds very well, while the gap from $0.62 \mathrm{~nm}$ to the plane of $(002) \mathrm{MOS}_{2}$ can be assigned. The presence of close contact between $\mathrm{MoS}_{2}$ /graphene nanosheets and $\mathrm{BiPO}_{4} \mathrm{NPs}$ is predictable for building a necessary hetero structure [180]. $\mathrm{BiPO}_{4} / \mathrm{rGO}$ NCs were successfully synthesized by a simple solvothermal method. This composite possessed much advanced and best photocurrent performance. The as-prepared PEC sensor revealed a broader lower detection limit, linear range, and an excellent anti-interference capacity. In the formation of chlorpyrifos, the Bi-chlorpyrifos complex formation on $\mathrm{BiPO}_{4} \mathrm{NPs}$ gave rise to an increase in steric hindrance. It thus stuck the $\mathrm{BiPO}_{4} \mathrm{NPs}$ electron transfer toward the electrode surface, causing an observable fall in photocurrent [182].

$\mathrm{rGO} / \mathrm{Bi}_{2} \mathrm{MoO}_{6}$ nanosheets were successfully synthesized using $\mathrm{rGO} / \mathrm{Bi}_{2}(\mathrm{EG})$ precursors using a two-stage solvothermal method. The introduction of graphene supports the recombination of electrons and holes generated by photogenerated $\mathrm{rGO} / \mathrm{Bi}_{2} \mathrm{MoO}_{6}$ nanocomposite exhibits plate-on-plate enhanced $\mathrm{Cr}(\mathrm{VI})$ photoreduction structures with radiation from sunlight. With an ideal photocatalytic activity, the $2.5 \% \mathrm{rGO} / \mathrm{Bi}_{2} \mathrm{MoO}_{6} \mathrm{com}$ posite and a reduction of $94 \%$ to $\mathrm{Cr}(\mathrm{VI})$ at about $30 \mathrm{~min}$, roughly twice that of pure $\mathrm{Bi}_{2} \mathrm{MoO}_{6}$. The $\mathrm{rGO}$, which mainly functions as an electron collector and meaningfully promotes the photoinduced carrier separation, accommodates the improved photocatalytic efficacy. Furthermore, $\mathrm{rGO} / \mathrm{Bi}_{2} \mathrm{MoO}_{6}$ composites have excellent stability and can be recycled in an industrial process. The composite morphologies of $2.5 \% \mathrm{rGO} / \mathrm{Bi}_{2} \mathrm{MoO}_{6}$ are low-lying and non-regular plate-on-plate structures. This indicates that $\mathrm{Bi}_{2} \mathrm{MoO}_{6}$ nanoflocks are scattered to the surface of large graphene layers forming $\mathrm{Bi}_{2} \mathrm{MoO}_{6}$ nanoflocks and small ribs. Defects may cause wrinkles during the functioning of oxygen when GO was synthesized $[184,185]$.

A newer BWO/MG ternary heterojunction photocatalyst was designed with an improved load carrier separation using the two-step hydrothermal method through a progressive load transfer route. $\mathrm{MoS}_{2}$ was used to improve the transition between graphene and BWO through the "stepping stone" approach. A positive synergetic effect between the graphene sheets and $\mathrm{MoS}_{2}$ is believed to occur. The cocatalyst components on photodegradation can efficiently improve the interfacial charge transfer, suppress the recombination of charges, and offer many photocatalytic reaction centers and active absorption sites [186]. The BWO/MG ternary hybrid facility is a visible and inexpensive environmental photocatalyst that expands the composite photocatalyst preparation range of MG hybrids and provides a prospective way to improve the performance of photocatalysts. The BWO catalyst has a microscopic structure and morphology with an average diameter of 3-4 microspheres. These microspheres consist of several hundred nanometers of lateral nanoplates. The BWO microspheres used the automatic spherical construction of nanosheet nanoplates. The SEM and TEM images of BWO and BWO/MG are shown in Figure 5. BWO nanosheets are not agglomerated during growth following MG modifications. The morphology of the BWO crystalline structures is controlled by the incorporation of MG, 
which has increased photocatalytic performance in a larger specific area. The photogenerated electrons should improve the photocatalytic efficiency and charging separation, a close relationship between $\mathrm{BWO}$, graphene, and components achieved via hydrothermal processing [187].

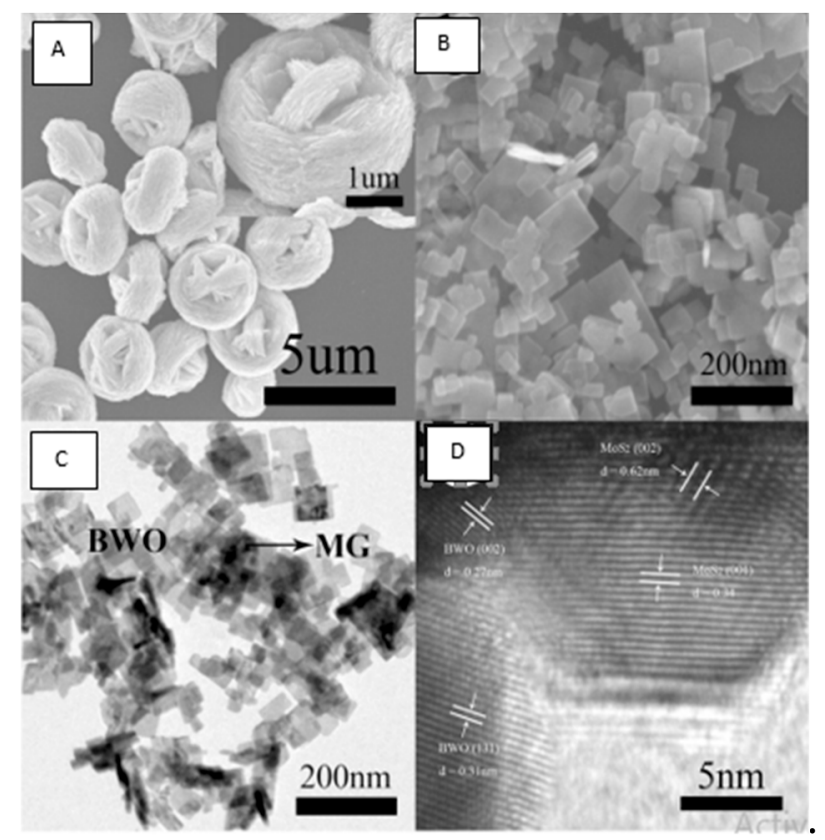

Figure 5. SEM images of (A) BWO and (B) BWO/MG. (C) TEM image of BWO/MG and (D) HRTEM of BWO/MG. Adapted from [187].

$\mathrm{Bi}_{2} \mathrm{WO}_{6} / \mathrm{rGO}$ photocatalysts have been synthesized by an easy hydrothermal method and with $2 \mathrm{wt} \% \mathrm{rGO}$ content display the highest photocatalyst performance. Enhanced photocatalytic activity for more efficient cargo transport, maximum light absorption, and separation can be accredited to strong chemical bonds between $\mathrm{rGO}$ and $\mathrm{Bi}_{2} \mathrm{WO}_{6}$. In addition, $\mathrm{Bi}_{2} \mathrm{WO}_{6} / \mathrm{rGO}$ is highly stable and essential for applications in environmental protection applications [188,189].

\subsection{Self-Assembly}

Self-assembly is a useful and frequently favored method for assembling micro- and nano- substances into macroscopic systems [190-192]. It is used to produce functional materials such as composites, photonic crystals, and DNA structures. An innovative way of synthesizing ordered graphene-metal oxide hybrids via a surfactant-supported, ternary self-assembly process was established to achieve an interchangeable layer structure of final composites [193]. The efficient and easy electrostatic self-montage method is successfully used to produce $\mathrm{BWO} / \mathrm{rGO}$ nanocomposites. BWO-nanocomposites RGO's have been synthesized with hydrothermal reduction through electrostatic self-assembly processes. The uniform, electronically interacting, and close interface contact can be achieved with nanocomposites from the BWO/rGO. The adjacent interface contact stimulates the separation of $\mathrm{e} / \mathrm{h}^{+}$pairs and extends the lifetime of the photo-induced charge carrier [194]. The charging balance and electronic interaction between $\mathrm{rGO}$ and BWO lead to VB change and change in conductive electricity and the valence band holes [195].

Nanocomposites of $\mathrm{GO} / \mathrm{BiPO}_{4}$ were synthesized using an easy self-assembly twophase method. The GO presence can substantially improve the visible light absorption of the load transfer facilitators, catalysts, and the pair of electron holes [196]. The GO/BiPO nanocomposites formation via a self-assembly method is shown in Figure 6. 


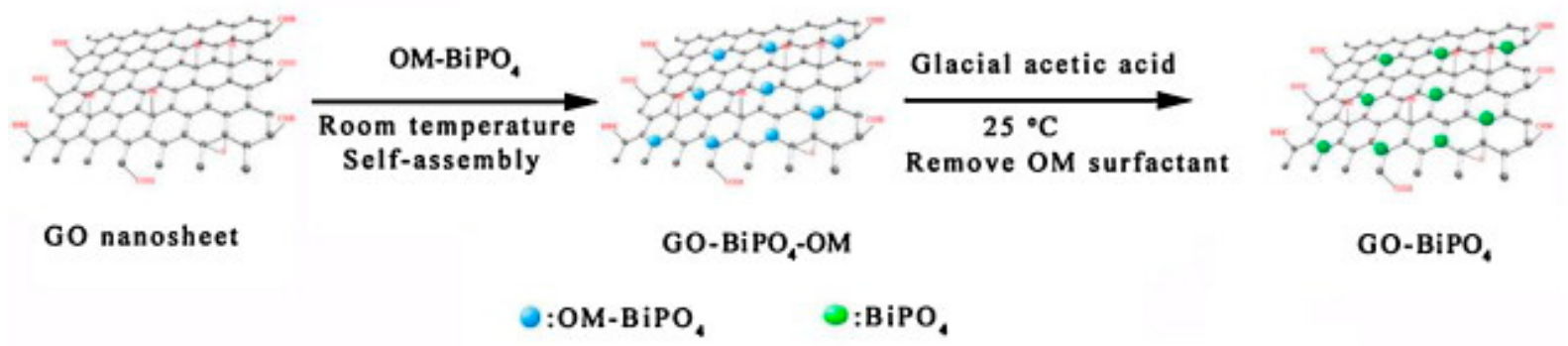

Figure 6. $\mathrm{GO}_{-} \mathrm{BiPO}_{4}$ nanocomposites formation via a self-assembly method. Adapted from [196].

An easy and fast approach to energy-generating chemical reactions is microwave irradiation. Graphene-metal oxide hybrids, for example, graphene- $\mathrm{MnO}_{2}$ have been synthesized using microwave irradiation [197] as has graphene- $\mathrm{Co}_{3} \mathrm{O}_{4}$ [198]. Direct electrochemical deposition of inorganic crystals on graphene substrates is an intelligent approach for thin film-based applications with no need for post-synthetic transfer of composite materials [199-209]. A summary of bismuth/graphene-based photocatalysts fabrication methods, morphology, and applications is presented in Table 2.

Table 2. Summary of bismuth/graphene-based photocatalyst fabrication methods, morphology, and applications.

\begin{tabular}{|c|c|c|c|c|}
\hline Photocatalyst & Activities & Morphology & Method & Refs. \\
\hline $\mathrm{Bi}_{2} \mathrm{MoO}_{6} / \mathrm{Au} / \mathrm{rGO}$ & RhB & lattice fringes & $\begin{array}{l}\text { solvothermal and photochemical } \\
\text { reduction }\end{array}$ & [20] \\
\hline $\begin{array}{l}\mathrm{BiPO}_{4} / \text { nitrogen-doped } \\
\text { graphene hydrogel }\end{array}$ & $\begin{array}{l}\text { biomedical, food and } \\
\text { environment analysis }\end{array}$ & porous structure & one-pot hydrothermal & [181] \\
\hline $\mathrm{BiPO}_{4} / \mathrm{GO}$ & $\mathrm{MB}$ & sphere-like/rod & two-phase self-assembly & [196] \\
\hline $\mathrm{BiPO}_{4} / \mathrm{MoS}_{2} /$ graphene & RhB & $\begin{array}{l}\text { lattice fringes with wrinkles and } \\
\text { folds }\end{array}$ & $\begin{array}{c}\text { one-pot microwave-assisted } \\
\text { hydrothermal }\end{array}$ & [180] \\
\hline $\mathrm{Bi}_{2} \mathrm{MoO}_{6} / \mathrm{Pd}-\mathrm{rGO}$ & phenol & microspheres/flake-like particles & $\begin{array}{l}\text { Solvothermal photoreduction } \\
\text { method }\end{array}$ & [200] \\
\hline BiOBr/Au/Graphene & phenol & flower-like microstructure & $\begin{array}{l}\text { hydrothermal synthesis and } \\
\text { reduction method }\end{array}$ & [141] \\
\hline $\mathrm{BiPO}_{4} / \mathrm{rGO}$ & Chlorpyrifos & nanoparticles/nanosheets & solvothermal method & {$[182]$} \\
\hline $\begin{array}{c}\mathrm{TiO}_{2}-\mathrm{Bi}_{2} \mathrm{O}_{3} /(\mathrm{BiO})_{2} \\
\mathrm{CO}_{3}-\mathrm{rGO}\end{array}$ & bisphenol A & nanoplates/nanosheet/nanorod & hydrothermal procedure & [159] \\
\hline TZB-Gr composite & $\mathrm{NO}$ & NPs /2D graphene sheets & $\begin{array}{l}\text { sol-gel based electrospinning } \\
\text { process }\end{array}$ & [175] \\
\hline $\begin{array}{c}\text { black } \\
\text { BiOCl-Bi-Bi } \mathrm{O}_{3} / \text { rGO }\end{array}$ & 2-nitrophenol (2NP) & nanosheets & $\begin{array}{l}\text { sonication and mechanical } \\
\text { stirring, in situ Fe reduction }\end{array}$ & [141] \\
\hline $\mathrm{BiPO}_{4}$-graphene & Methyl Orange MO & wrinkles and folds & one-step solvothermal & [183] \\
\hline $\mathrm{Bi}_{2} \mathrm{WO}_{6}-\mathrm{rGO}$ & $\mathrm{NO}$ & microspheres/nanosheets & hydrothermal method & [188] \\
\hline $\mathrm{Bi}_{2} \mathrm{MoO}_{6} / 2 \mathrm{D}-\mathrm{rGO}$ & $\mathrm{Cr}(\mathrm{VI})$ reduction & wrinkled nanoflakes & hydrothermal method & [184] \\
\hline BWO-RGO & bisphenol A degradation & uniform structure & hydrothermal treatment & [195] \\
\hline $\mathrm{Bi}_{2} \mathrm{MoO}_{6}-\mathrm{RGO}$ & bacterial destruction & highly oriented morphology & hydrothermal process & [107] \\
\hline $\mathrm{Bi}_{2} \mathrm{MoO}_{6} / \mathrm{Ag}_{3} \mathrm{PO}_{4} / \mathrm{RGO}$ & MB & $\begin{array}{l}\text { microspheres/flakes/irregular- } \\
\text { sphere }\end{array}$ & $\begin{array}{l}\text { precipitation-solvothermal } \\
\text { method }\end{array}$ & {$[178]$} \\
\hline $\mathrm{Bi} / \mathrm{BiOBr} / \mathrm{Graphene}$ & Degradation of RhB & $\begin{array}{l}\text { Nanosheets assemble into } \\
\text { flower-like microspheres }\end{array}$ & One-step solvothermal & [201] \\
\hline Bi-NPs/GO & $\begin{array}{l}\text { Remove ppb-level NO } \\
\text { Disinfection and }\end{array}$ & nanospheres & Solution-based sonication & [73] \\
\hline Bi-NPs/Graphene & $\begin{array}{l}\text { antibacterial activity } \\
\text { towards Escherichia coli }\end{array}$ & nanospheres & Non-injection facile strategy & {$[202]$} \\
\hline $\mathrm{PbBiO}_{2} \mathrm{Br} / \mathrm{GO}$ & $\mathrm{CO}_{2}$ conversion to $\mathrm{CH}_{4}$ & nanolayers & Hydrothermal synthesis & {$[203]$} \\
\hline h-BiVO $4 /$ rGO & $\begin{array}{l}\text { BPA degradation and } \mathrm{H}_{2} \\
\text { evolution }\end{array}$ & nanoplates embedded nanosheets & Ultrasonication & [204] \\
\hline $\mathrm{BiVO}_{4} / \mathrm{rGO}$ & MB degradation & nanoparticles & Hydrothermal synthesis & {$[205]$} \\
\hline $\mathrm{BiFeO}_{3} / \mathrm{N}-\mathrm{rGO}$ & RhB degradation & nanoparticles & $\begin{array}{l}\text { Sol-gel method followed by } \\
\text { hydrothermal synthesis }\end{array}$ & [206] \\
\hline BONPs-NG/NGO & Xylene removal & nanoplates embedded nanosheets & $\begin{array}{l}\text { Carbon vapor deposition, } \\
\text { stirring, and heating }\end{array}$ & [207] \\
\hline $\mathrm{Bi}\left(\mathrm{PO}_{4}\right) / \mathrm{GO}$ & Ciprofloxacin degradation & nanospheres embedded nanosheets & Cross-linker polymerization & {$[208]$} \\
\hline $\mathrm{BiVO}_{4} / \mathrm{rGO}$ & $\begin{array}{c}\text { Triethylamine (TEA) } \\
\text { detection }\end{array}$ & nanosheets wrapped with particles & Hydrothermal synthesis & [209] \\
\hline
\end{tabular}




\section{Applications of Bismuth/Graphene Nanohybrids}

Bismuth-graphene-based composites have been used for the photodegradation of pollutants and also in many other domains, such as hydrogen production and photovoltaic cells linked to environmental preservation [210-212].

\subsection{Water Splitting}

Hydrogen energy is considered as an ideal green energy source, and the product of hydrogen combustion is $\mathrm{H}_{2} \mathrm{O}$, so hydrogen, when used as fuel, it both solves the future fossil fuel crisis and shortage and lessens the environmental pollution from fossil fuel consumption [150,210,213-215]. In 1972, Fujishima et al. first described the $\mathrm{TiO}_{2}$ photoelectrode water splitting phenomenon [216], and as a result, photocatalytic $\mathrm{H}_{2}$ production has gained much attention [217-220]. Hydrogen is one of the crucial pure fuels [221-223]. Hydrogen production using the appropriate photocatalyst and solar power is an important factor not just because it is an excellent way to supply large-scale renewable and clean hydrogen but also to prevent probable energy-storage problems. One of the more convenient methods in this respect is photocatalytic water splitting. To date, some nanocomposites based on graphene have been used for the photocatalytic cleavage of water [220,224]. To transform this technology into an industrial application, the development and exploration of relevant photocatalysts with outstanding performance are vital. In the past four decades, therefore, several semiconductors were tested as photocatalysts. Graphene is considered to have a great performance in this research field $[225,226]$. In order to make a practical photocatalyst economically attainable, efforts have been made to improve the efficiency of the photocatalysts. Amal's group developed photocatalysts such as $\mathrm{rGO} / \mathrm{Ru} / \mathrm{Sr}, \mathrm{rGO} / \mathrm{BiVO}_{4}, \mathrm{rGO} / \mathrm{WO}_{3}$, and $\mathrm{TiO}_{3}, \mathrm{rGO} / \mathrm{TiO}_{2}[117,227,228]$. In the case of the $\mathrm{BiVO}_{4} / \mathrm{rGO}$ composite, the evolution of the $\mathrm{O}_{2}$ and $\mathrm{H}_{2}$ on $\mathrm{BiVO}_{4} / \mathrm{rGO}$ was $0.21 \mathrm{~mm}$ and $0.75 \mathrm{mmol} \mathrm{h}^{-1}$, respectively, under visible light, while negligible gas production is detected in pure cells of $\mathrm{BiVO}_{4}$. This photocatalytic water splitting has been accredited to the longer electron life of provoked $\mathrm{BiVO}_{4}$ electrons that promptly injected in rGO at the production site, leading to lower recombination of charges (Figure 7). In recent times, an inspired Z-scheme photocatalysis system for dividing water under visible light radiation has been established. Photocatalytic systems for the artificial Z-scheme offer a blossoming approach for enhancing the performance of $\mathrm{PH}$ 2, by imitating the natural photosynthesis in typical green leaves [229].
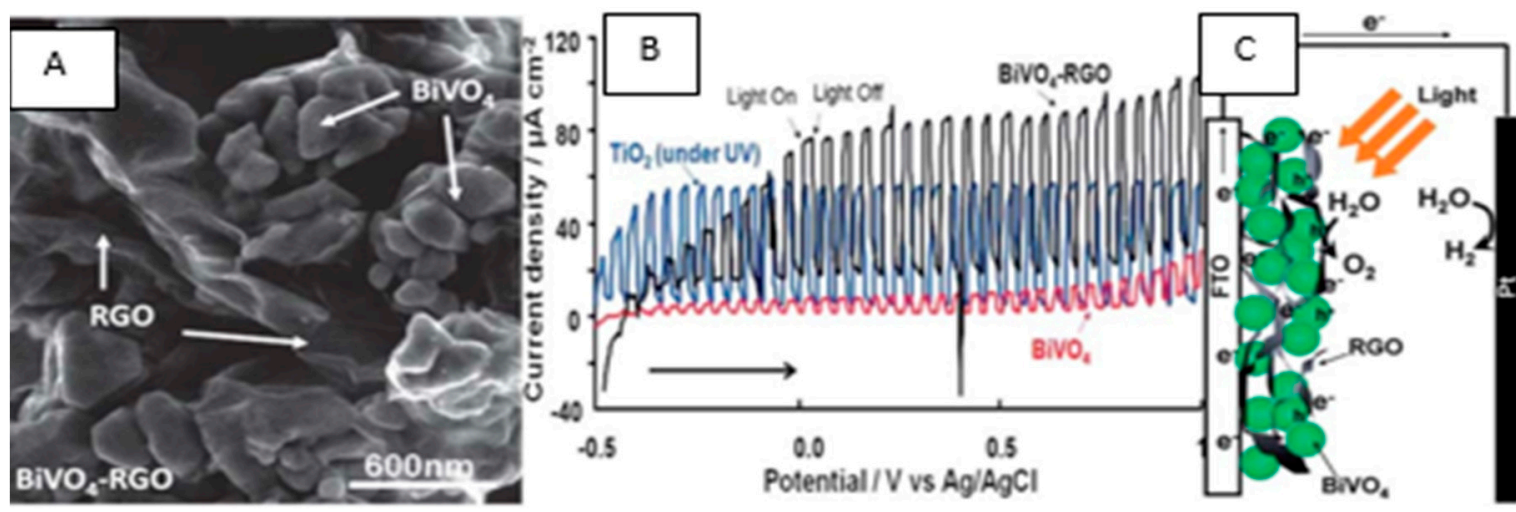

Figure 7. (A) SEM image of $\mathrm{BiVO}_{4} / \mathrm{rGO}$; (B) visible light voltage-photocurrent functions of $\mathrm{BiVO}_{4}, \mathrm{BiVO}_{4} / \mathrm{rGO}$, and TiO 2 (under UV irradiation); (C) illustration of photocatalytic water splitting in photoelectrochemical cell based on $\mathrm{BiVO}_{4} / \mathrm{rGO}$ Adapted from [224].

PVRO ( $\mathrm{PRGO} / \mathrm{BiVO}_{4}, \mathrm{PRGO}$ ) and $\mathrm{Ru} / \mathrm{SrTiO}_{3}$ photographic graphene oxide blends ( $\mathrm{PRGO} / \mathrm{Ru} / \mathrm{SrTiO}_{3}: \mathrm{Rh}$ ) can be synthesized in the presence of the photocatalytic reduction of $\mathrm{GO}$ on both $\mathrm{BiVO}_{4}$ and $\mathrm{Ru} / \mathrm{SrTiO}_{3}: \mathrm{Rh}$, in the presence of methanol as a hole scavenger. PRGO functions as a solid-state electron mediator in this system and transports electrons from the $\mathrm{BiVO}_{4} \mathrm{CB}$ to vacancies in the $\mathrm{Ru} / \mathrm{SrTiO}_{3}: \mathrm{Rh}$ impurity levels. In $\mathrm{Ru} / \mathrm{SrTiO}_{3}$ 
electrons, the water is reduced $\mathrm{H}_{2}$ by a Ru cocatalyst, and the water is oxidized into $\mathrm{O}_{2}$ by holes from $\mathrm{BiVO}_{4}$, thus producing a full water decomposition cycle. The $\mathrm{O}_{2}$ and $\mathrm{H}_{2}$ time cycles have demonstrated that after the second cycle, this system is constant. This important work provides a new entry to the use of g- $\mathrm{C}_{3} \mathrm{~N}_{4}$ in the design of new and efficient water division systems [224]. Chong et al. [230] reported $\mathrm{V}_{2} \mathrm{O}_{5} / \mathrm{rGO} / \mathrm{BiVO}_{4}$ heterojunction (Figure 8) as an efficient photo-electrochemical water division photoanode.
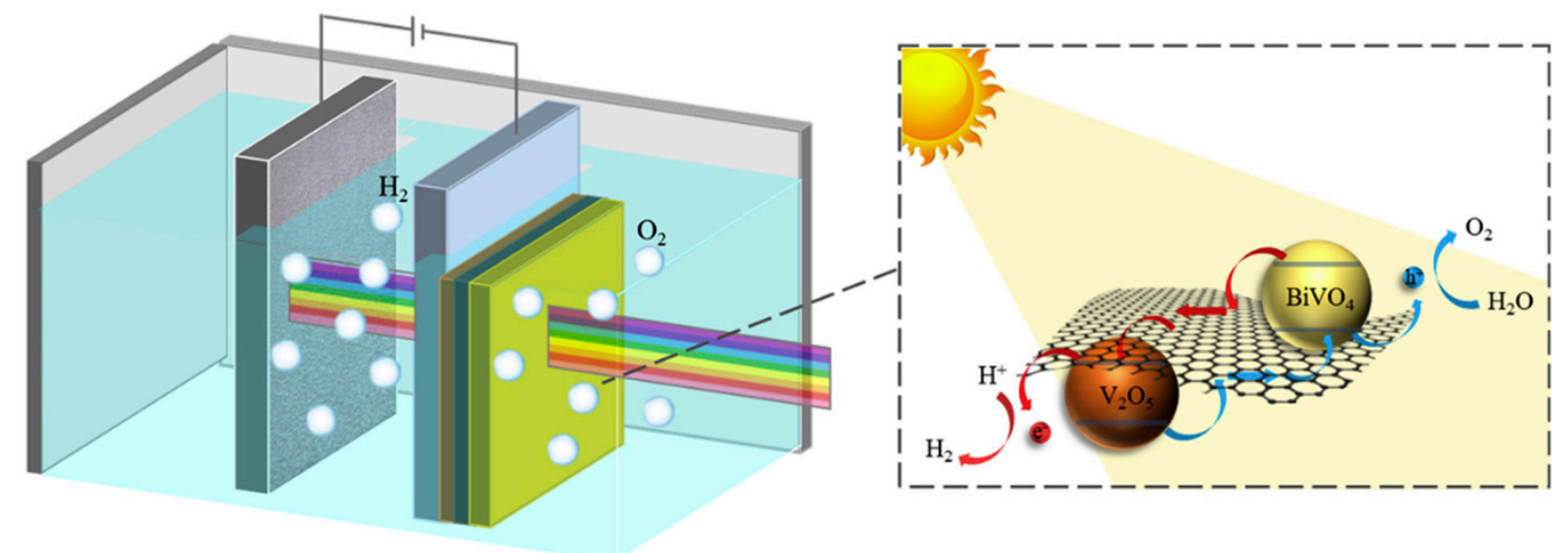

Figure 8. Photoelectrochemical water splitting system design and electron transfer mechanism schematics in $\mathrm{V}_{2} \mathrm{O}_{5} /$ $\mathrm{rGO} / \mathrm{BiVO}_{4}$ heterojunction photoanode. Adapted from [230].

\section{2. $\mathrm{CO}_{2}$ Reduction}

Due to growing energy and environmental concerns, $\mathrm{CO}_{2}$ conversion into fuel is considered a favorable approach [231-233]. Solar energy is mainly used for this due to its capacity to imitate the natural photosynthesis process to transform solar energy into chemical energy. The photocatalytic reduction of $\mathrm{CO}_{2}$ into valued fuels like formic acid, methane, and methanol is of particular importance [234-236]. In the last decades, this has received great attention and we have become acquainted with the enhanced release of the greenhouse gas $\mathrm{CO}_{2}$ into our atmosphere and the potential and real power supply shortage. The conversion of solar power into chemicals by photoelectrochemically or photocatalytically reducing $\mathrm{CO}_{2}$, is also one of the most advantageous methods to solve environmental and energy problems simultaneously. $\mathrm{CO}_{2}$ molecules are chemically inert and therefore highly stable, with linear geometry and shell electronics [235]. The $\mathrm{CO}_{2}$ reduction by photosensitive semiconductor catalysts yields highly sought products, e.g., formic acid, methane, formaldehyde, and methanol, etc. Several compounds, including metal complexes, can function as electrocatalysts for $\mathrm{CO}_{2}$ reduction $[235,236]$. Bismuth and graphene's role is vital and has been studied widely in $\mathrm{CO}_{2}$ conversion to valued products. Bismuth is prominently used through electrochemical $\mathrm{CO}_{2}$ reduction reactions (ECRR), while there are several reports of photocatalysis by a bismuth-graphene nanohybrid catalyst. Sun el al. converted $\mathrm{CO}_{2}$ into formate using bismuth with bismuth oxides supported on graphene nanosheets $\left(\mathrm{Bi} / \mathrm{Bi}_{2} \mathrm{O}_{3} / \mathrm{NrGO}\right)$. This hybrid electrocatalyst gives a high current density and low overpotential in ECRR due to the synergistic effect of bismuth and its oxides [237]. Similarly, a bismuth oxide-reduced graphene oxide quantum dots ( $\mathrm{rGO} / \mathrm{BiO}$ QDs) composite was synthesized, which provides excess photoelectrons and protons for $\mathrm{CO}_{2}$ reduction [238]. In another study, a nanoheterojunction electrocatalyst made of zinc phthalocyanine/graphene $/ \mathrm{BiVO}_{4}$ showed higher performance than the $\mathrm{BiVO}_{4}$ nanocatalysts due to the modulating presence of graphene [239]. Using defect engineering, oxygen vacancy-rich electrocatalysts were prepared by Yang et al. [240]. The electrocatalysts were prepared by a precipitation method from bismuth oxide and bismuth sulfide supported on reduced graphene oxide. This hybrid nanocatalyst facilitates $\mathrm{CO}$ and formate formation during ECRR at low overpotential with high stability during on-stream analysis. A lead bismuth oxobromide/graphene oxide catalyst was prepared and studied 
for the conversion of $\mathrm{CO}_{2}$ into methane under light [203]. The graphene-supported catalyst activity was much higher than without graphene, reflecting the importance of graphene in future environmental and energy conversion and storage applications. More research on bismuth graphene composites is needed in this field [241]. Figure 9 presents an electron transfer mechanism and reducing adsorption and formate formation from $\mathrm{CO}_{2}$ molecules over the $\mathrm{BiVO}_{4}$ quantum dots/rGO composite $[242,243]$.
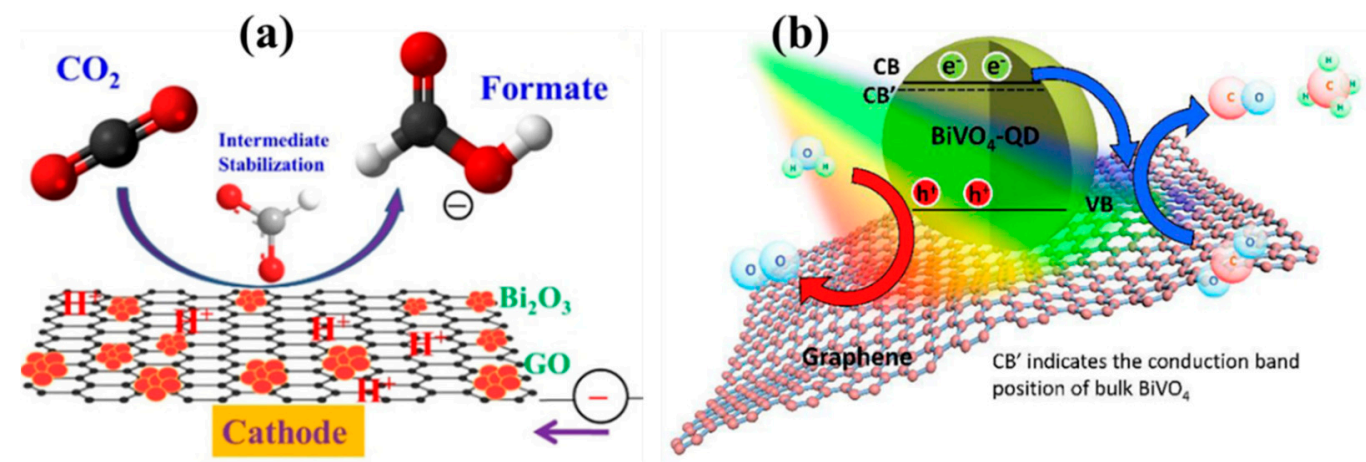

Figure 9. (a) The electron transfer and reduction mechanism: a) adsorption of $\mathrm{CO}_{2}$ molecules, b) intermediate stabilization, and c) formate formation with desorption of formate in the electrolyte. (b) Schematic of charge transfer, separation, and the reaction of $\mathrm{BiVO}_{4}$ quantum dots/rGO composites for $\mathrm{CO}_{2}$ reduction. Adapted from [242,243].

\subsection{Other Applications \\ 4.3.1. $\mathrm{NO}_{\mathrm{x}}$ Conversion}

In addressing environmental problems associated with water and air pollutants, photocatalytic processes in decomposition and inorganic compounds, along with the removal of dangerous gases, are of great importance [244-247]. The main pollutants caused by the combustion of industrial burners or fossil fuel in automotive engines are nitric oxide (NO) and nitric dioxide $\left(\mathrm{NO}_{2}\right)$ [248]. Many catalytic processes for the transformation of nitrogen gases (e.g., $\mathrm{NO}$ and $\mathrm{NO}_{2}$ ) into nitrogen $\left(\mathrm{N}_{2}\right)$, oxygen $\left(\mathrm{O}_{2}\right)$, or nitrate $\left(\mathrm{NO}_{3}{ }^{-}\right)$have been established $[249,250]$. An ideal NOx conversion catalyst transforms NOx gases at lower-temperature [251]. $\mathrm{TiO}_{2}$ is one of the leading catalysts for the catalytic conversion of NOx gases into nitrous oxide $\left(\mathrm{N}_{2} \mathrm{O}\right)$ and $\mathrm{N}_{2}[252,253]$. The majority of previous studies on the conversion of NOx gases have involved different lasers [254], spectroscopic (such as infrared (IR), [255], and chemiluminescence (CL) [256] or electrochemical techniques [257] for the detection of NOx reaction products. The use of high-resolution MS for biomedical applications to detect NO [230] and indirectly semiconducting metal oxides [231] has been described. The main cause of water pollution is industrial wastewater discharge. Drinking polluted water for a long time poses potential health risks, and can also cause cancer, teratogenicity and mutagenicity. For this reason, it is very important to develop suitable techniques for the treatment of industrial wastewater to meet emission standards. Photocatalysis is considered a sustainable and efficient water treatment technology. Oldphotocatalysts (such as $\mathrm{ZnO}$ and $\mathrm{TiO}_{2}$ ) with a wide bandgap are only active in the UV light region and their quick recombination of photo-generated holes and electrons leads to low quantum efficiencies that limit their application for wastewater treatment. The traditional inconveniences of these photocatalysts requires the development of new Bi-based semi-

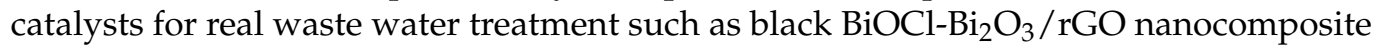
with high photocatalytic efficiency [141].

With economic growth, pollution, primarily air pollution, is becoming a serious concern and must be treated instantaneously. NOx plays an important role in acid rain formation, diseases and photochemistry. Therefore, the elimination of NOx is a hot topic in the area of environmental protection [258-261]. The photocatalytic oxidation of $\mathrm{NO}$ to $\mathrm{NO}_{2}$ is a good way to remove $\mathrm{NO}$ from flue gas, as $\mathrm{NO}_{2}$ can be removed simply by reacting with hydrocarbons to release $\mathrm{N}_{2}$ or water [262]. The photocatalytic $\mathrm{NO}-\mathrm{NO}_{2}$ oxidation 
is observed as an essential reaction, and a great deal of effort has been made to develop appropriate NO-removal photocatalysts $[263,264] . \mathrm{Bi}_{2} \mathrm{WO}_{6}$ has attracted considerable attention as an Aurivillius oxide semiconductor with a $2.66 \mathrm{eV}$ narrow bandgap. $\mathrm{Bi}_{2} \mathrm{WO}_{6}$ forms with different morphology can be synthesized by various approaches, like a cetyltrimethylammonium bromide-assisted bottom-up route, hydrothermal processes and solidstate reactions [265-267]. It was used in several applications, including the decomposition of pollutants $[266,267]$. However, the photocatalytic activity fades due to fast recombination of photogenerated carriers in $\mathrm{Bi}_{2} \mathrm{WO}_{6}$, and its more practical applications are restricted. Graphene has been shown to successfully improve photocatalysts' photoactivities through further separation of the electron-holes generated and helping photoinduced electrons to migrate and preventing the recombination of electron-holes and increasing the efficiency of quantization [268-270]. Bismuth compounds have also been employed in combination with graphene to produce useful photocatalytic composites for NOx removal under visible light irradiation [271]. Zhihui et al. [272] prepared BiOBr-graphene nanocomposites for efficient removal of NO via visible-light photocatalytic activity. The improved photocatalytic activity of the BiOBr-graphene nanocomposite was ascribed to the efficient charge separation, and enhanced transfer is due to robust chemical bonding between graphene and $\mathrm{BiOBr}$. Also, the $\mathrm{N}_{2}$-doped $(\mathrm{BiO})_{2} \mathrm{CO}_{3} / \mathrm{GO}$ nanocomposites, reported by Chen et al., [273], play a pivotal role in higher photocatalytic performance for NOx removal under visible light irradiation. The rGO improved the electron-hole separation for pure $\mathrm{Bi}_{2} \mathrm{WO}_{6}$ and fully degrading $\mathrm{RhB}$ [274]. Ma et al. described an improved composite performance of $\mathrm{rGO} / \mathrm{Bi}_{2} \mathrm{WO}_{6}$ photocatalytic in phenol and RhB degradations [275]. The selective photocatalytic 4-NP reduction on blank nanocomposites $\mathrm{BWO}, \mathrm{rGO}$ and $\mathrm{BWO} / \mathrm{rGO}$ after $30 \mathrm{~min}$ of irradiation is shown in Figure 10.

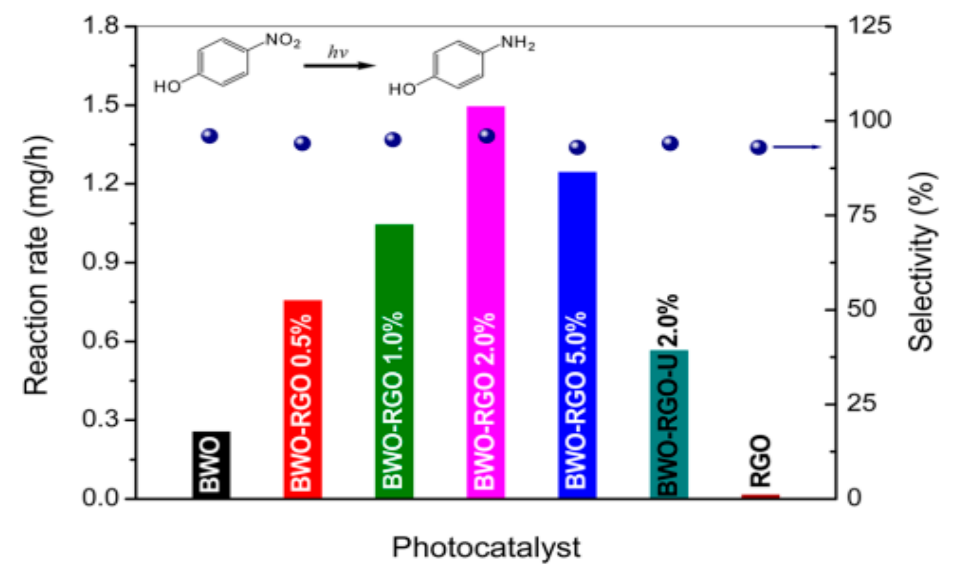

Figure 10. Photocatalytic selective reduction of 4-NP to 4-AP over blank BWO, RGO, and BWO/rGO nanocomposites after irradiation for $30 \mathrm{~min}$. Source: Adapted from [195].

\subsubsection{Organic Degradation}

A dramatic surge in research in the visible light photocatalysis area was observed at the start of the 21st century, as evidenced by a promptly increasing number of publications. Using visible light in combination with catalysts is effective for producing selective and efficient chemical transformations. Nature remarkably reveals the power of photosynthesis by transforming $\mathrm{CO}_{2}$ and $\mathrm{H}_{2} \mathrm{O}$ into oxygen and carbohydrates, a process that is so far unequaled by any man-made chemical procedure [276].

The use in organic synthesis of solar energy as a motiving power is now beginning. Key solar energy components include UV $(\lambda=200-400 \mathrm{~nm})$, visible light $(\lambda=400-800 \mathrm{~nm})$, and infrared light $(\lambda>800 \mathrm{~nm})$, accounting for almost $5 \%, 43 \%$, and $52 \%$, respectively. UV energy can directly trigger certain organic molecules to provide highly reactive intermediates, resulting in poor product selectivity. Furthermore, for the vast majority of organic reactions, the infrared wavelength with relatively low energy does not meet the energy 
demand. In comparison, UV and visible light are abundant, but the reactant molecules can usually not directly adsorb them to drive reactions. Therefore, it will be important for visible photocatalysts to work as bridging media for energy transfer between the substrate and visible light. These photocatalysts may be assigned to five different groups: plasmonic-metal NPs, homogenous photocatalysts, opposite heterogeneous semiconductor photocatalysts, other new photoelectric materials, and organic dyes. Various semiconductors show different widths and positions of the string so that there are different reduction and oxidation potential for the electrons and hole pairs created in situ. When the carriers (holes and electrons) travel to the catalyst surface, which lowers photo-catalytic efficiency, electron and hole pair recombination occurs frequently. Many approaches have been developed to improve the separation efficiency of electron-hole pairs, such as supporting a photocatalyst on graphene with a big surface or using a valuable metal materials such as $\mathrm{Pt}$ so photogenerated charge transfer could be accelerated.

In organic reactions, $\mathrm{H}_{2} \mathrm{O}$ is considered an ideal solvent. However, the problem is that, under photocatalytic conditions, the semiconductor VB hole can oxidize $\mathrm{H}_{2} \mathrm{O}$ into a highly active $\mathrm{OH}$ radical form, making the reaction system complicated. $\mathrm{Bi}_{2} \mathrm{WO}_{6}$ photocatalyst $\mathrm{VB}^{\prime}$ s inherent reduction potential is $+1.77 \mathrm{~V}$ vs. $\mathrm{Ag} / \mathrm{AgCl}$, which is negative to the $\mathrm{H}_{2} \mathrm{O} / \mathrm{ANOH} . \mathrm{H}_{2} \mathrm{O}$ as a solvent is possible when $\mathrm{Bi}_{2} \mathrm{WO}_{6}$ is used as a catalyst. Recently, a selective oxidation of benzyl alcohols into aldehydes has been effectively developed with a $\mathrm{Bi}_{2} \mathrm{WO}_{6} / \mathrm{H}_{2} \mathrm{O} /$ air system [277]. Although the different synthetic applications of visible light photocatalysis are awe-inspiring, there is still scope for improvement. In several instances, the reaction times for many conversions are fairly long. In order to make photocatalytic changes faster and more energy-efficient, the quantum efficiency must be extremely enhanced. A better mechanistic consideration could benefit the rational design of new transformations and the expectation of the substrate scope. The reachable potential should be stretched for the exchange of chemically reduced single-electron or stoichiometric oxidizing reagents by photocatalytic reactions. There is no examination of the various photocatalytic energies of transformations, and chemists have just begun to produce organic conversions that are promising with additional light energies. Finally, we must find out how this can be extended to ions and carbenes and how the common visible light's common photocatalytic reactions continue through the radical intermediates. There are plenty of opportunities for future development in photocatalysis. We should have followed Ciamician's initial ideas for sustainable and innovative organic syntheses using visible light much earlier [278].

In comparison with applications such as organic contaminant degradation, heterogeneous semi-conducting photocatalysis addresses more complex problems. The photoinduced charging transfers resulting from semiconductor interfaces with holes or electrons used as reducers and oxidizers, respectively, are the basis of all types of photocatalytic applications. In photocatalytic selective organic synthesis, the critical problem is how to regulate the method of interfacial charge transfer to ensure only the selective transformation of specific functional groups in organic substrata while the remaining molecular structure remains intact [279]. Because the VB holes photogenerated as a stable photocatalyst (e.g., $\mathrm{WO}_{3}, \mathrm{TiO}_{2}$, and $\mathrm{ZnO}$ ) have strong oxidation power, $\mathrm{VB}$ holes tend to oxidize nonselectively and degrade whole molecules, respectively. For RhB degradation, $\mathrm{BiOCl} / \mathrm{rGO}$ is considered an effective photocatalyst [280]. The mechanism is schematically shown in Figure 11. At present, there are several technical difficulties and knowledge gaps in the organic synthesis research field. The photocatalytic method is heterogeneous. It is expected that individual photocatalysts will offer enhanced selectiveness for selective reactions, similar to organic degradation processes. It is estimated that for individual organic synthesis reaction cases, each photocatalyst must be optimized as selectivity control depends on the molecular structure and the particular organic substrate characteristics as well as on the photocatalyst [281]. 

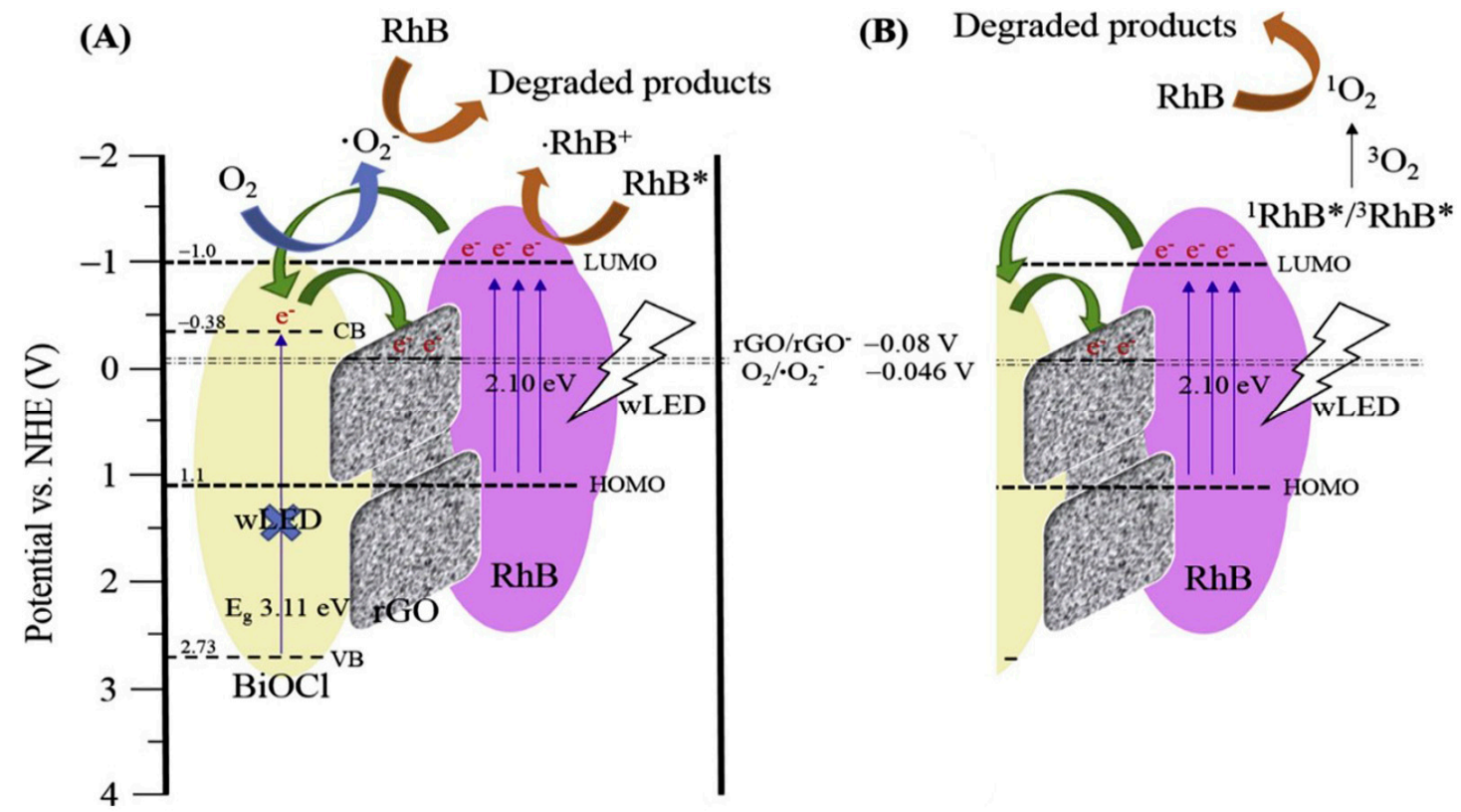

Figure 11. Illustration of the $\mathrm{RhB}$ degradation mechanism via $\mathrm{BiOCl} / \mathrm{rGO}$ photocatalysts by $(\mathbf{A}) \cdot \mathrm{O}_{2}{ }^{-}$radicals and (B) single oxygen under the white LED irradiation. Adapted from [280].

As an efficient, non-toxic, and stable method, photocatalytic disinfection was shown to be superior to traditional methods for water disinfection, including UV irradiation, ozonation and chlorination, since they form carcinogenic disinfection by-products, and are causes of global warming due to the formation of chemical-intensive or energy-intensive products. Highly successful and innovative wastewater disinfection approaches need to be implemented and maintained, that are less dependent on fossil fuels and chemicals [282]. In particular, rationally designed nanophotocatalyst nanomaterials have tremendous potential here to produce robust and adequate reactive species using solar light (the most plentiful, and accessible renewable energy source on Earth). The bactericidal activity of photocatalysts sextends to all reactive species formed during the photocatalytic process. In addition, visible light corresponds to the strongest solar irradiance range. A photocatalyst, which can efficiently absorb the visible light to produce reactive species, is a condition for achieving fast photocatalytic disinfection [283]. Jamshaid et al. [284] synthesized a $\mathrm{BiOCl} / \mathrm{GO}$ composite and utilized it under visible light, full solar light, and UV photocatalytic degradation of diclofenac sodium (DCF) (Figure 12).

As a photocatalyst, $\mathrm{BiVO}_{4} / \mathrm{rGO}$ nanocomposite exhibits efficient catalytic activity towards organic dye degradation $[285,286]$. The photodegradation results showed that the $\mathrm{BiVO}_{4}-\mathrm{rGO}$ nanocomposite catalyst could effectively degrade organic dyes in a variety of wastewaters. Similarly, a one-step hydrothermally synthesized $\mathrm{Bi}^{-} \mathrm{TiO}_{2} /$ graphene nanocomposite is considered an efficient photocatalyst for remarkable organic pollutant degradation under visible light irradiation [287]. The Z-scheme photocatalyst systems provided a promising approach of simultaneously removing heavy metals and organic pollutants. Acong et al. [288] reported an all-solid-state Z-scheme system containing $\mathrm{BiOI} / \mathrm{Bi}_{2} \mathrm{~S}_{3} / \mathrm{rGO}$ composites for simultaneous removal of aqueous $\mathrm{Cr}(\mathrm{VI})$ and phenol [288]. A series of bismuth-graphene nanocomposite systems were summarized by Yu-Hsun et al. [289] for adequate catalytic activity and stability, acting as visible-light-driven photocatalysts in efficient organic pollutant degradation. 

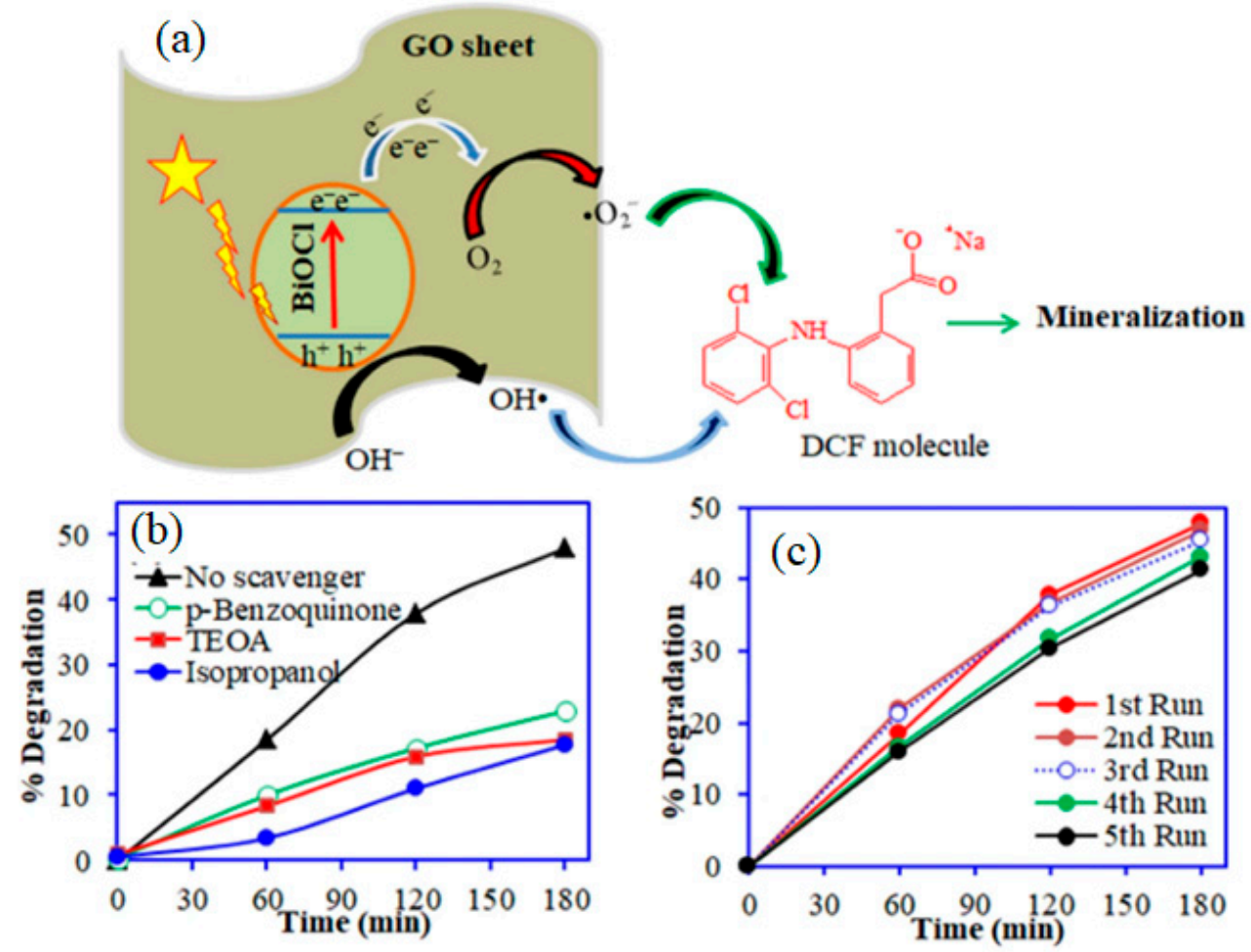

Figure 12. (a) Schematic representation for DCF photocatalytic degradation mechanism onto $\mathrm{BiOCl} / \mathrm{GO}$ composite, (b) Effect of different scavengers on DCF degradation, and (c) plot for regeneration of spent $\mathrm{BiOCl} / \mathrm{GO}$ composite. Copied from [284].

\subsubsection{Gas Sensing}

The exploitation and design of photoelectrochemical (PEC) sensors with innovative nanomaterials are of great significance to attain the goal of inexpensive and sensitive detection. Therefore, $\mathrm{BiPO}_{4} / \mathrm{rGO}$ nanocomposite, a novel PEC sensor platform, can offer a delicate approach in chlorpyrifos detection and the resulting $\mathrm{BiPO}_{4} / \mathrm{rGO}$ nanocomposite is a potentially active catalyst for the PEC-related applications (Figure 13) [182].

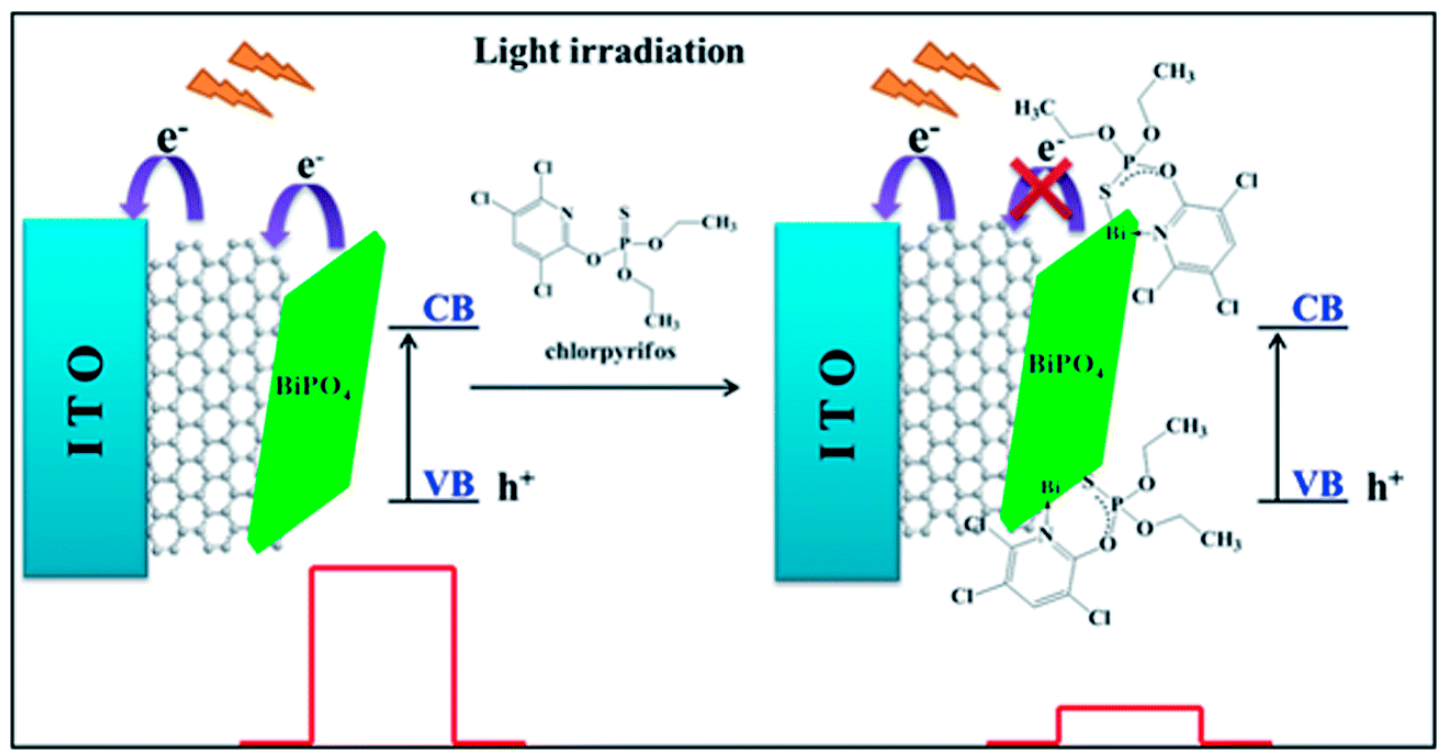

Figure 13. The PEC sensor illustration for chlorpyrifos. Adapted from ref [182]. 
In the modern nanotechnology field, considerable attention has been given to an architecture-controlled combination of nanomaterials because of their astonishing chemical and physical properties and promising applications in different fields, e.g., optics, electronics, catalysis, and so on $[290,291]$. Similarly, using innovative configurations with implanted graphene for a broad surface, long electron life can be supported by other photonic devices such as solar cells and non-photonic devices, like lithium batteries and biochemical sensors. Low band-gap energy, reduced recombination rate, and fast charge transit e.g., spiral rolls-implanted graphene in the $\mathrm{TiO}_{2} / \mathrm{ZnO} / \mathrm{Bi}_{2} \mathrm{O}_{3}$ (TZB) nanofiber $[175,292]$. The $\mathrm{BiPO}_{4} / 3 \mathrm{DNGH}$ and $\mathrm{BiVO}_{4} / \mathrm{rGO}$ provide a new platform for specific biomedical, food, and environmental detection applications $[181,293,294]$. TEA and $\mathrm{H}_{2} \mathrm{~S}$ are highly toxic gases that can pollute the atmosphere and damage the human respiratory system. Consequently, it is important to be able to easily detect low levels of TEA and $\mathrm{H}_{2} \mathrm{~S}$ in our everyday lives. Shouli et al. [209] developed a pine dendritic $\mathrm{BiVO}_{4} / \mathrm{rGO}$ hybrid heterojunction, which improves not only $\mathrm{BiVO}_{4}$ response and speeds up the response time but also has good selectivity and stability to $10 \mathrm{ppm}$ TEA at $180{ }^{\circ} \mathrm{C}$ operating temperature. The formation of heterojunction and the integration of rGO are responsible for the change. Ketkaeo et.al. [295] investigated $\mathrm{Bi}_{2} \mathrm{WO}_{6}$ nanoparticles loaded with rGO nanosheets for $\mathrm{H}_{2} \mathrm{~S}$ gas sensing applications. The developed sensor exhibited high $\mathrm{H}_{2} \mathrm{~S}$ selectivity against numerous volatile organic compounds and some other environmental gases. The $\mathrm{H}_{2} \mathrm{~S}$ sensing mechanism via $\mathrm{Bi}_{2} \mathrm{WO}_{6} / \mathrm{rGO}$ composite is illustrated in Figure 14.

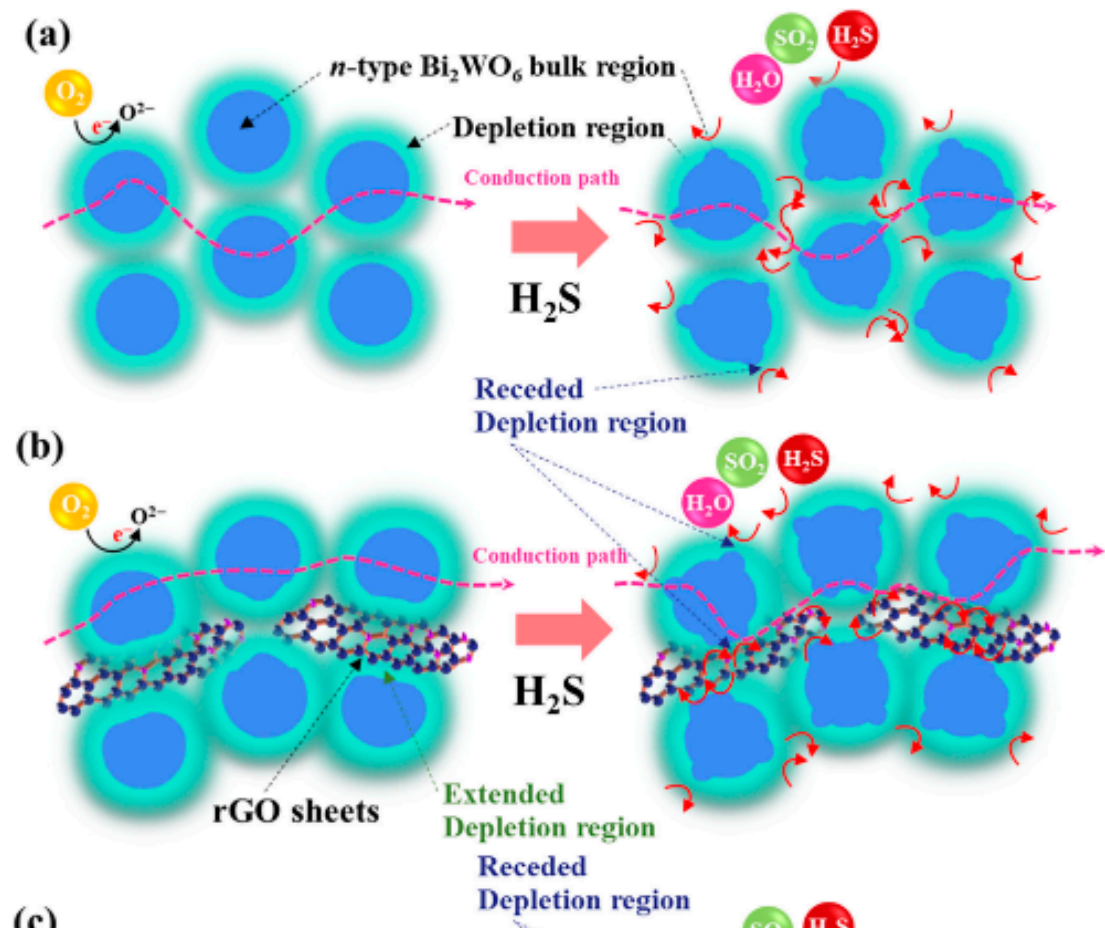

(c)

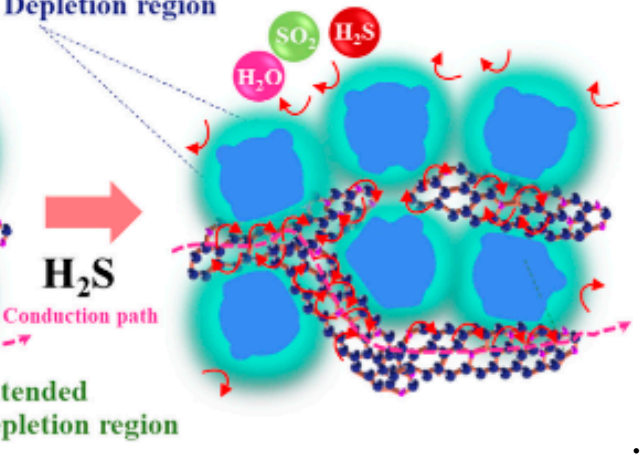

Figure 14. $\mathrm{H}_{2} \mathrm{~S}$ sensing approaches via (a) $\mathrm{Bi}_{2} \mathrm{WO}_{6}$ nanoparticles, (b) moderate loaded $\mathrm{rGO}$ over $\mathrm{Bi}_{2} \mathrm{WO}_{6}$ nanoparticles, and (c) high loaded $\mathrm{rGO}$ over $\mathrm{Bi}_{2} \mathrm{WO}_{6}$ nanoparticles. Adapted from [295]. 


\section{Drawbacks/Challenges Related to Bismuth and Graphene}

Although, there has been diversified study on bismuth and graphene nanohybrids for large-scale applications of such photocatalysts, there remains several drawbacks/challenges such as the site of attachment of dopant, the overall efficient doping mechanism, assessment of integration, photocatalyst degradation, and visible light absorption that remain to be unraveled.

The improved Hummers process has been commonly used to synthesize graphene, which is the most recent and best method. However, despite the low experimental complexity, the experimental procedures to complete the graphene fabrication are time-consuming. As a result, the substitution or elimination of such chemicals must be studied further to reduce fabrication times and produce a better fabrication processes. Furthermore, the amount of chemicals used in the fabrication process or replacing them with less expensive alternatives could make the whole process more cost-effective and applicable to real-world applications.

Challenges also remain in the exploration of graphene-based nanohybrids for high performance practical applications. High-quality graphene nanohybrids with tailored functionalization, tunable structures, and optimized properties need to be fabricated in a more simple, effective, and economical approach. In graphene functionalization, attention must be paid to the control distribution, amount, and affinity to graphene nanosheets and the dispersibility and functionality of nanohybrids.

Graphene sheets tend to form aggregates in solution due to hydrogen bonding or strong van der Waals force interactions in polar solvents. Chemical functionalization [291,296] and electrostatic stabilization [297] are used to avoid this aggregation. Graphene reduction using simple methods facilitates graphene applications to synthesize composite materials in cost-effective, scalable approaches with low cost of production $[167,298]$. GOs may be synthesized using the Hummers and Offeman method and then by sonication exfoliated using strong graphite chemical oxidation. Most studies have concentrated on $\mathrm{Bi}^{3+}$-containing compounds, like $\mathrm{Bi}_{2} \mathrm{O}_{3} \mathrm{BiOX}(\mathrm{X}=\mathrm{Cl}, \mathrm{Br}, \mathrm{I}), \mathrm{BiPO}_{4}, \mathrm{BiVO}_{4}$, $\mathrm{BiFeO}_{3} \mathrm{Bi}_{4} \mathrm{Ti}_{3} \mathrm{O}_{12}, \mathrm{Bi}_{2} \mathrm{WO}_{6}, \mathrm{Bi}_{2} \mathrm{O}_{2} \mathrm{CO}_{3}, \mathrm{Bi}_{12} \mathrm{TiO}_{20}, \mathrm{Bi}_{0.5} \mathrm{~K}_{0.5} \mathrm{TiO}_{3}$, and $\mathrm{Bi}_{3} \mathrm{TiNbO}_{9}$. Among them, a majority of the compounds possess a plate-like appearance and layered structures. Visible light can excite $\mathrm{Bi}^{5+}$-containing compounds, e.g., $\mathrm{KBiO}_{3}, \mathrm{LiBiO}_{3}$, and $\mathrm{NaBiO}_{3}$. $\mathrm{Hy}$ bridized $\mathrm{O} 2 \mathrm{p}$ and $\mathrm{Bi} 6 \mathrm{~s}_{2}$ orbitals can influence the valence bands in $\mathrm{Bi}(\mathrm{III})$ compounds (VBs). Therefore, the Bi compounds' band gap is usually less than $3.0 \mathrm{eV}$ and can easily be excited by visible light. However, the photocatalytic performance of bulk Bi-based semiconductors is not as high as the performance of photocatalysts from nano Bi-sources, like photogenerated holes and electrons have not been used and used efficiently. The photocatalysts in bulk are smaller in area and have less light absorption than photocatalysts in the nanoscale range. A variety of attempts to improve bulk semiconductors have been made to achieve the ideal photocatalytic activity. In addition, changes in components, e.g., doping, alteration of stoichiometry, and preparation of solid solutions, are current methods used to change the Bi-based semiconductor band structures. Therefore for Bi photocatalysts, a suitable component change is promising [25]. It has been studied that the $\mathrm{Bi}_{6}$ s-orbital decreases the bandgap while increasing photogenerated charge carriers' mobility [299]. While a majority of the Bi-based compounds have about a $3.0 \mathrm{eV}$ bandgap. Bi-based compounds, including $\mathrm{Bi}_{2} \mathrm{O}_{3}, \mathrm{Bi}_{2} \mathrm{MO}_{6}(\mathrm{M}=\mathrm{W}, \mathrm{Mo}$, and $\mathrm{Cr}), \mathrm{BiVO}_{4}, \mathrm{BiOX}(\mathrm{X}=\mathrm{I}$, $\mathrm{Br}$ and $\mathrm{Cl}), \mathrm{BiPO}_{4}$, pentavalent bismuthate and $(\mathrm{BiO})_{2} \mathrm{CO}_{3}$, were tested as a large number of photocatalytic compounds. In environmental protection applications, Bi-based semiconductors have been used for the oxidation of gaseous pollutants, such as NO [105], organic dye degradation in wastewater [300], and $\mathrm{CO}_{2}$ photoreduction [94]. During various studies, photocatalytic water division for generating $\mathrm{O}_{2}$ and $\mathrm{H}_{2}$ was reported [301].

An efficient strategy considered a new approach for improving bare photocatalysts' catalytic performance is by combining a new Z-scheme structure with the appropriate band position. The Z-scheme design can retain a high redox capacity to forgive both semiconductors, except for e-h pairs' recombination. Thanks to the band structure's 
adaption, environmental ease, and low cost, graphene was reported as another component by modifying Bi to change a Z-scheme system and doping [302].

\section{Summary and Outlook}

Future developments would be part of the present start of this new century. Bi/graphenebased semiconductors' fascinating physiochemical features have attracted researchers' attention and significantly motivated research, especially on visible-light photocatalytic activities. This review has discussed the most frequently studied bismuth/graphene photocatalysts. In addition, key challenges, including the broad bandwidth, high photogeneration carrier recombination rates, and low-capacity reduction in the conduction band, are outlined. The work reported has supported recommending achievable approaches to overcome these challenges. Though photocatalysts based on bismuth/graphene can considerably lessen the inconvenience, further efforts are still necessary to achieve significant advancements.

To date, these prepared bismuth/graphene materials' major applications are to purify polluted air and destroy pollutants in wastewater. Applying the formation of Z-scheme structures or modifying energy bands, improves the photocatalytic $\mathrm{H}_{2}$ production. The work on these advanced nanocomposites should extend to other major areas, such as photocatalytic improvements, photocatalytic organic synthesis, and the recovery of heavy metals. The practical uses of photocatalysts using bismuth/graphene are seldom described. Integrating the application in different directions and many other areas with other suitable techniques, such as biotechnology, membrane technology, and electrochemistry, can lead to rapid advancements. Although many nanocomposites with bismuth/graphene have been reported to be active using visible and high photocatalytic light, the use of these advanced materials is still in the early stages of commercialization. Photocatalysts can selectively degrade pollutants.

Nanomaterial photocatalysis, especially nanophotocatalysts, exhibits huge potential because solar light can produce powerful and abundant reactive species. The visible light range is intended to achieve maximum photocatalytic decontamination and fast output rates. A photocatalyst capable of efficiently absorbing visible light is a prerequisite for producing reactive species. Two well-investigated visible-light-driven photocatalysts among various semiconductors are bismuth (Bi) and graphene. Due to their chemical stability, bulk availability, they have great potential for water disinfection applications and environmental friendliness. A bismuth/graphene hybrid effectively suppressed $\mathrm{e}^{-}$and $\mathrm{h}^{+}$pair recombination, promoted the interfacial electron transfer, and enhanced the photocatalytic process of reactive species generation. While this review is incomplete in the context of photocatalytic pollutant breakdown of bismuth/graphene nanocomposites, important aspects have been addressed concerning fundamental applications and principles.

Author Contributions: Conceptualization, M.U., M.H., A.K. and H.U. (Habib Ullah ${ }^{4}$ ); validation, M.H., A.K., A.AT., S.S.S., H.U. (Habib Ullah ${ }^{3}$ ), M.U., S.S.S. and H.U. (Habib Ullah ${ }^{4}$ ); writingoriginal draft preparation, M.U.; writing—-review and editing, M.H., A.K. and H.U. (Habib Ullah ${ }^{4}$ ); visualization, M.H., A.K., A.AT., H.U. (Habib Ullah ${ }^{3}$ ), S.S.S., M.U. and H.U. (Habib Ullah ${ }^{4}$ ); supervision, A.AT., A.K. and H.U. (Habib Ullah ${ }^{4}$ ); All authors have read and agreed to the published version of the manuscript.

Funding: This research received no external funding.

Acknowledgments: We are thankful to the Engineering and Physical Science Research Council, UK (EPSRC under the research grant no. EP/V049046/1 and EP/T025875/, for financial support. M. U also acknowledges the support from Saudi Aramco Chair Programme (ORCP2390).

Conflicts of Interest: The authors declare no conflict of interest. 


\section{References}

1. Srivastva, N.; Shukla, A.K.; Singh, R.S.; Upadhyay, S.N.; Dubey, S.K. Characterization of bacterial isolates from rubber dump site and their use in biodegradation of isoprene in batch and continuous bioreactors. Bioresour. Technol. 2015, 188, 84-91. [CrossRef] [PubMed]

2. Shahimin, M.F.M.; Foght, J.M.; Siddique, T. Preferential methanogenic biodegradation of short-chain n-alkanes by microbial communities from two different oil sands tailings ponds. Sci. Total Environ. 2016, 553, 250-257. [CrossRef]

3. $\mathrm{Hu}, \mathrm{Y}$;; Wang, Z.; Wen, J.; Li, Y. Stochastic fuzzy environmental risk characterization of uncertainty and variability in risk assessments: A case study of polycyclic aromatic hydrocarbons in soil at a petroleum-contaminated site in China. J. Hazard. Mater. 2016, 316, 143-150. [CrossRef]

4. Yeh, C.-H.; Lin, C.-W.; Wu, C.-H. A permeable reactive barrier for the bioremediation of BTEX-contaminated groundwater: Microbial community distribution and removal efficiencies. J. Hazard. Mater. 2010, 178, 74-80. [CrossRef] [PubMed]

5. Chen, L.; Liu, Y.; Liu, F.; Jin, S. Treatment of co-mingled benzene, toluene and TCE in groundwater. J. Hazard. Mater. 2014, 275, 116-120. [CrossRef]

6. Zhou, Y.; Gao, F.; Zhao, Y.; Lu, J. Study on the extraction kinetics of phenolic compounds from petroleum refinery waste lye. J. Saudi Chem. Soc. 2014, 18, 589-592. [CrossRef]

7. Ali, S.M.; Pervaiz, A.; Afzal, B.; Hamid, N.; Yasmin, A. Open dumping of municipal solid waste and its hazardous impacts on soil and vegetation diversity at waste dumping sites of Islamabad city. J. King Saud Univ. Sci. 2014, 26, 59-65. [CrossRef]

8. Hu, G.; Li, J.; Zeng, G. Recent development in the treatment of oily sludge from petroleum industry: A review. J. Hazard. Mater. 2013, 261, 470-490. [CrossRef]

9. Ashraf, M.; Khan, I.; Usman, M.; Khan, A.; Shah, S.S.; Khan, A.Z.; Saeed, K.; Yaseen, M.; Ehsan, M.F.; Tahir, M.N.; et al. Hematite and Magnetite Nanostructures for Green and Sustainable Energy Harnessing and Environmental Pollution Control: A Review. Chem. Res. Toxicol. 2020, 33, 1292-1311. [CrossRef]

10. Shah, S.S.; Qasem, M.A.A.; Berni, R.; Del Casino, C.; Cai, G.; Contal, S.; Ahmad, I.; Siddiqui, K.S.; Gatti, E.; Predieri, S.; et al. Physico-chemical properties and toxicological effects on plant and algal models of carbon nanosheets from a nettle fibre clone. Sci. Rep. 2021, 11, 6945. [CrossRef] [PubMed]

11. Mymrin, V.; Pedroso, A.M.; Ponte, H.A.; Ponte, M.J.; Alekseev, K.; Evaniki, D.; Pan, R.C. Thermal engineering method application for hazardous spent petrochemical catalyst neutralization. Appl. Therm. Eng. 2017, 110, 1428-1436. [CrossRef]

12. Sun, J.; Watson, S.S.; Allsopp, D.A.; Stanley, D.; Skrtic, D. Tuning photo-catalytic activities of $\mathrm{TiO}_{2}$ nanoparticles using dimethacrylate resins. Dent. Mater. 2016, 32, 363-372. [CrossRef]

13. Ehsan, M.F.; Fazal, A.; Hamid, S.; Arfan, M.; Khan, I.; Usman, M.; Shafiee, A.; Ashiq, M.N. CoFe ${ }_{2} \mathrm{O}_{4}$ decorated g-C3N4 nanosheets: New insights into superoxide anion mediated photomineralization of methylene blue. J. Environ. Chem. Eng. 2020, 8,104556 [CrossRef]

14. Khan, I.; Khan, I.; Usman, M.; Imran, M.; Saeed, K. Nanoclay-mediated photocatalytic activity enhancement of copper oxide nanoparticles for enhanced methyl orange photodegradation. J. Mater. Sci. Mater. Electron. 2020, 31, 8971-8985. [CrossRef]

15. Ehsan, M.F.; Shafiq, M.; Hamid, S.; Shafiee, A.; Usman, M.; Khan, I.; Ashiq, M.N.; Arfan, M. Reactive oxygen species: New insights into photocatalytic pollutant degradation over g-C3N4/ZnSe nanocomposite. Appl. Surf. Sci. 2020, 532, 147418. [CrossRef]

16. Singh, P.; Borthakur, A. A review on biodegradation and photocatalytic degradation of organic pollutants: A bibliometric and comparative analysis. J. Clean. Prod. 2018, 196, 1669-1680. [CrossRef]

17. Wang, Z.; Yang, Y.; Dai, Y.; Xie, S. Anaerobic biodegradation of nonylphenol in river sediment under nitrate-or sulfate-reducing conditions and associated bacterial community. J. Hazard. Mater. 2015, 286, 306-314. [CrossRef]

18. Luna, A.L.; Valenzuela, M.A.; Colbeau-Justin, C.; Vázquez, P.; Rodriguez, J.L.; Avendaño, J.R.; Alfaro, S.; Tirado, S.; Garduño, A.; José, M. Photocatalytic degradation of gallic acid over $\mathrm{CuO}-\mathrm{TiO}_{2}$ composites under UV/Vis LEDs irradiation. Appl. Catal. A Gen. 2016, 521, 140-148. [CrossRef]

19. Pan, C.; Zhu, Y. A review of BiPO 4, a highly efficient oxyacid-type photocatalyst, used for environmental applications. Catal. Sci. Technol. 2015, 5, 3071-3083. [CrossRef]

20. Bi, J.; Fang, W.; Li, L.; Li, X.; Liu, M.; Liang, S.; Zhang, Z.; He, Y.; Lin, H.; Wu, L. Ternary reduced-graphene-oxide/Bi2MoO6/Au nanocomposites with enhanced photocatalytic activity under visible light. J. Alloys Compd. 2015, 649, 28-34. [CrossRef]

21. Rostamnia, S.; Doustkhah, E.; Golchin-Hosseini, H.; Zeynizadeh, B.; Xin, H.; Luque, R. Efficient tandem aqueous room temperature oxidative amidations catalysed by supported Pd nanoparticles on graphene oxide. Catal. Sci. Technol. 2016, 6, 4124-4133. [CrossRef]

22. Ravelli, D.; Dondi, D.; Fagnoni, M.; Albini, A. Photocatalysis. A multi-faceted concept for green chemistry. Chem. Soc. Rev. 2009, 38, 1999-2011. [CrossRef] [PubMed]

23. Hayat, A.; Rahman, M.U.; Khan, I.; Khan, J.; Sohail, M.; Yasmeen, H.; Liu, S.-Y.; Qi, K.; Lv, W. Conjugated Electron Donor-Acceptor Hybrid Polymeric Carbon Nitride as a Photocatalyst for $\mathrm{CO}_{2}$ Reduction. Molecules 2019, 24, 1779. [CrossRef] [PubMed]

24. Noh, M.F.M.; Ullah, H.; Arzaee, N.A.; Ab Halim, A.; Rahim, M.A.F.A.; Mohamed, N.A.; Safaei, J.; Nasir, S.N.F.M.; Wang, G.; Teridi, M.A.M. Rapid fabrication of oxygen defective $\alpha-\mathrm{Fe}_{2} \mathrm{O}_{3}(110)$ for enhanced photoelectrochemical activities. Dalton Trans. 2020, 49, 12037-12048.

25. Samsudin, M.F.R.; Ullah, H.; Tahir, A.A.; Li, X.; Ng, Y.H.; Sufian, S. Superior photoelectrocatalytic performance of ternary structural BiVO4/GQD/g-C3N4 heterojunction. J. Colloid Interface Sci. 2021, 586, 785-796. [CrossRef] [PubMed] 
26. Zhou, P.; Yu, J.; Jaroniec, M. All-solid-state Z-scheme photocatalytic systems. Adv. Mater. 2014, 26, 4920-4935. [CrossRef]

27. Humayun, M.; Sun, N.; Raziq, F.; Zhang, X.; Yan, R.; Li, Z.; Qu, Y.; Jing, L. Synthesis of ZnO/Bi-doped porous LaFeO 3 nanocomposites as highly efficient nano-photocatalysts dependent on the enhanced utilization of visible-light-excited electrons. Appl. Catal. B Environ. 2018, 231, 23-33. [CrossRef]

28. Humayun, M.; Zada, A.; Li, Z.; Xie, M.; Zhang, X.; Qu, Y.; Raziq, F.; Jing, L. Enhanced visible-light activities of porous BiFeO 3 by coupling with nanocrystalline $\mathrm{TiO}_{2}$ and mechanism. Appl. Catal. B Environ. 2016, 180, 219-226. [CrossRef]

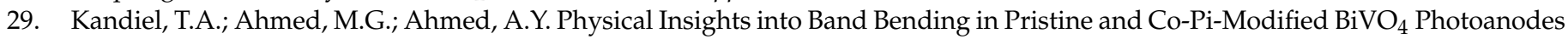
with Dramatically Enhanced Solar Water Splitting Efficiency. J. Phys. Chem. Lett. 2020, 11, 5015-5020. [CrossRef]

30. Zhang, H.H.; Cao, Y.M.; Usman, M.; Li, L.J.; Li, C.S. Study on the Hydrotreating Catalysts Containing Phosphorus of Coal Tar to Clean Fuels. Adv. Mater. Res. 2012, 531, 263-267. [CrossRef]

31. Kan, T.; Sun, X.; Wang, H.; Li, C.; Muhammad, U. Production of Gasoline and Diesel from Coal Tar via Its Catalytic Hydrogenation in Serial Fixed Beds. Energy Fuels 2012, 26, 3604-3611. [CrossRef]

32. Usman, M.; Li, D.; Razzaq, R.; Latif, U.; Muraza, O.; Yamani, Z.H.; Al-Maythalony, B.A.; Li, C.; Zhang, S. Poly aromatic hydrocarbon (naphthalene) conversion into value added chemical (tetralin): Activity and stability of MoP/AC catalyst. J. Environ. Chem. Eng. 2018, 6, 4525-4530. [CrossRef]

33. Li, X.; Wen, J.; Low, J.; Fang, Y.; Yu, J. Design and fabrication of semiconductor photocatalyst for photocatalytic reduction of $\mathrm{CO}_{2}$ to solar fuel. Sci. China Mater. 2014, 57, 70-100. [CrossRef]

34. Chong, M.N.; Jin, B.; Chow, C.W.; Saint, C. Recent developments in photocatalytic water treatment technology: A review. Water Res. 2010, 44, 2997-3027. [CrossRef]

35. Bard, A.J.; Fox, M.A. Artificial photosynthesis: Solar splitting of water to hydrogen and oxygen. Acc. Chem. Res. 1995, 28, 141-145. [CrossRef]

36. Chen, X.; Mao, S.S. Titanium dioxide nanomaterials: Synthesis, properties, modifications, and applications. Chem. Rev. 2007, 107, 2891-2959. [CrossRef]

37. Alsaiari, N.S.; Katubi, K.M.M.; Alzahrani, F.M.; Siddeeg, S.M.; Tahoon, M.A. The Application of Nanomaterials for the Electrochemical Detection of Antibiotics: A Review. Micromachines 2021, 12, 308. [CrossRef] [PubMed]

38. Alwattar, J.K.; Mneimneh, A.T.; Abla, K.K.; Mehanna, M.M.; Allam, A.N. Smart Stimuli-Responsive Liposomal Nanohybrid Systems: A Critical Review of Theranostic Behavior in Cancer. Pharmaceutics 2021, 13, 355. [CrossRef] [PubMed]

39. Amir, M.N.I.; Halilu, A.; Julkapli, N.M.; Ma'amor, A. Gold-graphene oxide nanohybrids: A review on their chemical catalysis. J. Ind. Eng. Chem. 2020, 83, 1-13. [CrossRef]

40. Ali Tahir, A.; Ullah, H.; Sudhagar, P.; Asri Mat Teridi, M.; Devadoss, A.; Sundaram, S. The application of graphene and its derivatives to energy conversion, storage, and environmental and biosensing devices. Chem. Record 2016, 16, 1591-1634. [CrossRef]

41. Ullah, H.; Tahir, A.A.; Mallick, T.K. Polypyrrole/ $\mathrm{TiO}_{2}$ composites for the application of photocatalysis. Sens. Actuators B 2017, 241, 1161-1169. [CrossRef]

42. Sabeeh, H.; Aadil, M.; Zulfiqar, S.; Rasheed, A.; Al-Khalli, N.F.; Agboola, P.O.; Haider, S.; Warsi, M.F.; Shakir, I. Hydrothermal synthesis of CuS nanochips and their nanohybrids with CNTs for electrochemical energy storage applications. Ceram. Int. 2021, 47, 13613-13621. [CrossRef]

43. Safaei, J.; Ullah, H.; Mohamed, N.A.; Mohamad Noh, M.F.; Soh, M.F.; Tahir, A.A.; Ahmad Ludin, N.; Ibrahim, M.A.; Wan Isahak, W.N.R.; Mat Teridi, M.A. Enhanced photoelectrochemical performance of Z-scheme g- $\mathrm{C}_{3} \mathrm{~N}_{4} / \mathrm{BiVO}_{4}$ photocatalyst. Appl. Catal. B 2018, 234, 296-310. [CrossRef]

44. Liang, C.; Zhang, X.; Wang, Z.; Wang, W.; Yang, M.; Dong, X. Organic/inorganic nanohybrids rejuvenate photodynamic cancer therapy. J. Mater. Chem. B 2020, 8, 4748-4763. [CrossRef]

45. Corredor, L.M.; Husein, M.M.; Maini, B.B. A review of polymer nanohybrids for oil recovery. Adv. Colloid Interface Sci. 2019, 272, 102018. [CrossRef]

46. Ahmed, W.; Gul, S.; Awais, M.; Hassan, Z.U.; Jabeen, S.; Farooq, M. A review: Novel nanohybrids of epoxy/polyamide with carbon nanotube/nano-diamond. Polym. Plast. Technol. Mater. 2021, 60, 579-600.

47. Freag, M.S.; Elzoghby, A.O. Protein-inorganic Nanohybrids: A Potential Symbiosis in Tissue Engineering. Curr. Drug. Targets 2018, 19, 1897-1904. [CrossRef]

48. Ding, X.; Li, D.; Jiang, J. Gold-based Inorganic Nanohybrids for Nanomedicine Applications. Theranostics 2020, 10, 8061-8079. [CrossRef]

49. Park, D.-H.; Hwang, S.-J.; Oh, J.-M.; Yang, J.-H.; Choy, J.-H. Polymer-inorganic supramolecular nanohybrids for red, white, green, and blue applications. Prog. Polym. Sci. 2013, 38, 1442-1486. [CrossRef]

50. Mohan, V.B.; Lau, K.-T.; Hui, D.; Bhattacharyya, D. Graphene-based materials and their composites: A review on production, applications and product limitations. Compos. Part B Eng. 2018, 142, 200-220. [CrossRef]

51. Abu Nayem, S.M.; Shaheen Shah, S.; Sultana, N.; Aziz, M.A.; Saleh Ahammad, A.J. Electrochemical Sensing Platforms of Dihydroxybenzene: Part 1-Carbon Nanotubes, Graphene, and their Derivatives. Chem. Rec. 2021, in press. [CrossRef]

52. Gong, Y.; Li, M.; Li, H.; Wang, Y. Graphitic carbon nitride polymers: Promising catalysts or catalyst supports for heterogeneous oxidation and hydrogenation. Green Chem. 2015, 17, 715-736. [CrossRef]

53. Allen, M.J.; Tung, V.C.; Kaner, R.B. Honeycomb Carbon: A Review of Graphene. Chem. Rev. 2010, 110, 132-145. [CrossRef] 
54. Lee, X.J.; Hiew, B.Y.Z.; Lai, K.C.; Lee, L.Y.; Gan, S.; Thangalazhy-Gopakumar, S.; Rigby, S. Review on graphene and its derivatives: Synthesis methods and potential industrial implementation. J. Taiwan Inst. Chem. Eng. 2019, 98, 163-180. [CrossRef]

55. Li, X.; Yu, J.; Wageh, S.; Al-Ghamdi, A.A.; Xie, J. Graphene in Photocatalysis: A Review. Small 2016, 12, 6640-6696. [CrossRef] [PubMed]

56. Guo, B.; Fang, L.; Zhang, B.; Gong, J.R. Graphene doping: A review. Insciences J. 2011, 1, 80-89. [CrossRef]

57. Chabot, V.; Higgins, D.; Yu, A.; Xiao, X.; Chen, Z.; Zhang, J. A review of graphene and graphene oxide sponge: Material synthesis and applications to energy and the environment. Energy Environ. Sci. 2014, 7, 1564-1596. [CrossRef]

58. Wang, H.; Maiyalagan, T.; Wang, X. Review on Recent Progress in Nitrogen-Doped Graphene: Synthesis, Characterization, and Its Potential Applications. ACS Catal. 2012, 2, 781-794. [CrossRef]

59. Yang, G.; Li, L.; Lee, W.B.; Ng, M.C. Structure of graphene and its disorders: A review. Sci. Technol. Adv. Mater. 2018, 19, 613-648. [CrossRef]

60. Si, C.; Sun, Z.; Liu, F. Strain engineering of graphene: A review. Nanoscale 2016, 8, 3207-3217. [CrossRef]

61. Young, R.J.; Kinloch, I.A.; Gong, L.; Novoselov, K.S. The mechanics of graphene nanocomposites: A review. Compos. Sci. Technol. 2012, 72, 1459-1476. [CrossRef]

62. Zhang, Y.; Zhang, L.; Zhou, C. Review of Chemical Vapor Deposition of Graphene and Related Applications. Acc. Chem. Res. 2013, 46, 2329-2339. [CrossRef]

63. Yu, W.; Sisi, L.; Haiyan, Y.; Jie, L. Progress in the functional modification of graphene/graphene oxide: A review. RSC Adv. 2020, 10, 15328-15345. [CrossRef]

64. Meng, F.; Lu, W.; Li, Q.; Byun, J.-H.; Oh, Y.; Chou, T.-W. Graphene-Based Fibers: A Review. Adv. Mater. 2015, $27,5113-5131$. [CrossRef]

65. Xiong, G.; Meng, C.; Reifenberger, R.G.; Irazoqui, P.P.; Fisher, T.S. A Review of Graphene-Based Electrochemical Microsupercapacitors. Electroanalysis 2014, 26, 30-51. [CrossRef]

66. Baumert, B.A. Barium potassium bismuth oxide: A review. J. Supercond. 1995, 8, 175-181. [CrossRef]

67. Fang, W.; Shangguan, W. A review on bismuth-based composite oxides for photocatalytic hydrogen generation. Int. J. Hydrog. Energy 2019, 44, 895-912. [CrossRef]

68. Gao, T.; Chen, Z.; Huang, Q.; Niu, F.; Huang, X.; Qin, L.; Huang, Y. A review: Preparation of bismuth ferrite nanoparticles and its applications in visible-light induced photocatalyses. Rev. Adv. Mater. Sci. 2015, 40, 97-109.

69. Huang, Z.-F.; Pan, L.; Zou, J.-J.; Zhang, X.; Wang, L. Nanostructured bismuth vanadate-based materials for solar-energy-driven water oxidation: A review on recent progress. Nanoscale 2014, 6, 14044-14063. [CrossRef]

70. Zhang, L.; Zhu, Y. A review of controllable synthesis and enhancement of performances of bismuth tungstate visible-light-driven photocatalysts. Catal. Sci. Technol. 2012, 2, 694-706. [CrossRef]

71. Sharma, K.; Dutta, V.; Sharma, S.; Raizada, P.; Hosseini-Bandegharaei, A.; Thakur, P.; Singh, P. Recent advances in enhanced photocatalytic activity of bismuth oxyhalides for efficient photocatalysis of organic pollutants in water: A review. J. Ind. Eng. Chem. 2019, 78, 1-20. [CrossRef]

72. Kumar, R.; Raizada, P.; Verma, N.; Hosseini-Bandegharaei, A.; Thakur, V.K.; Le, Q.V.; Nguyen, V.-H.; Selvasembian, R.; Singh, P. Recent advances on water disinfection using bismuth based modified photocatalysts: Strategies and challenges. J. Clean. Prod. 2021, 297, 126617. [CrossRef]

73. Li, X.; Zhang, W.; Cui, W.; Sun, Y.; Jiang, G.; Zhang, Y.; Huang, H.; Dong, F. Bismuth spheres assembled on graphene oxide: Directional charge transfer enhances plasmonic photocatalysis and in situ DRIFTS studies. Appl. Catal. B Environ. 2018, 221, 482-489. [CrossRef]

74. Meng, X.; Zhang, Z. Bismuth-based photocatalytic semiconductors: Introduction, challenges and possible approaches. J. Mol. Catal. A Chem. 2016, 423, 533-549. [CrossRef]

75. Wang, Y.; Wen, Y.; Ding, H.; Shan, Y. Improved structural stability of titanium-doped $\beta-\mathrm{Bi}_{2} \mathrm{O}_{3}$ during visible-light-activated photocatalytic processes. J. Mater. Sci. 2010, 45, 1385-1392. [CrossRef]

76. Zhu, G.; Que, W.; Zhang, J. Synthesis and photocatalytic performance of Ag-loaded $\beta-\mathrm{Bi}_{2} \mathrm{O}_{3}$ microspheres under visible light irradiation. J. Alloys Compd. 2011, 509, 9479-9486. [CrossRef]

77. Ma, S.; Zhan, S.; Jia, Y.; Shi, Q.; Zhou, Q. Enhanced disinfection application of Ag-modified g- $\mathrm{C}_{3} \mathrm{~N}_{4}$ composite under visible light. Appl. Catal. B Environ. 2016, 186, 77-87. [CrossRef]

78. Samsudin, M.F.R.; Ullah, H.; Bashiri, R.; Mohamed, N.M.; Sufian, S.; Ng, Y.H. Experimental and DFT insights on microflower $\mathrm{g}-\mathrm{C}_{3} \mathrm{~N}_{4} / \mathrm{BiVO}_{4}$ photocatalyst for enhanced photoelectrochemical hydrogen generation from lake water. ACS Sustain. Chem. Eng. 2020, 8, 9393-9403. [CrossRef]

79. Ullah, H.; Tahir, A.A.; Mallick, T.K. Structural and electronic properties of oxygen defective and Se-doped p-type BiVO 4 (001) thin film for the applications of photocatalysis. Appl. Catal. B 2018, 224, 895-903. [CrossRef]

80. Lin, X.; Xu, D.; Zhao, R.; Xi, Y.; Zhao, L.; Song, M.; Zhai, H.; Che, G.; Chang, L. Highly efficient photocatalytic activity of g-C3N4 quantum dots (CNQDs) $/ \mathrm{Ag} / \mathrm{Bi}_{2} \mathrm{MoO}_{6}$ nanoheterostructure under visible light. Sep. Purif. Technol. 2017, 178, 163-168. [CrossRef]

81. Lin, X.; Xi, Y.; Zhao, R.; Shi, J.; Yan, N. Construction of C60-decorated SWCNTs (C60-CNTs)/bismuth-based oxide ternary heterostructures with enhanced photocatalytic activity. RSC Adv. 2017, 7, 53847-53854. [CrossRef]

82. Tian, Q.; Zhuang, J.; Wang, J.; Liu, P. Novel photocatalyst, $\mathrm{Bi}_{2} \mathrm{Sn}_{2} \mathrm{O}_{7}$, for photooxidation of As (III) under visible-light irradiation. Appl. Catal. A Gen. 2012, 425, 74-78. [CrossRef] 
83. Zhang, L.; Wang, W.; Yang, J.; Chen, Z.; Zhang, W.; Zhou, L.; Liu, S. Sonochemical synthesis of nanocrystallite $\mathrm{Bi}_{2} \mathrm{O}_{3}$ as a visible-light-driven photocatalyst. Appl. Catal. A Gen. 2006, 308, 105-110. [CrossRef]

84. Lin, X.P.; Huang, F.Q.; Wang, W.D.; Zhang, K.L. A novel photocatalyst $\mathrm{BiSbO}_{4}$ for degradation of methylene blue. Appl. Catal. A Gen. 2006, 307, 257-262. [CrossRef]

85. Zhang, Y.; Yu, H.; Li, S.; Wang, L.; Huang, F.; Guan, R.; Li, J.; Jiao, Y.; Sun, J. Rapidly degradation of di-(2-ethylhexyl) phthalate by $\mathrm{Z}$-scheme $\mathrm{Bi}_{2} \mathrm{O}_{3} / \mathrm{TiO}_{2} @$ reduced graphene oxide driven by simulated solar radiation. Chemosphere 2021, 272, 129631. [CrossRef]

86. Ren, G.; Ren, X.; Ju, W.; Jiang, Y.; Han, M.; Dong, Z.; Yang, X.; Dou, K.; Xue, B.; Li, F. Controlled vertical growing of Bi ${ }_{2} \mathrm{O}_{3}$ nano sheets on diatomite disks and its high visible-light photocatalytic performance. J. Photochem. Photobiol. A Chem. 2020, $392,112367$. [CrossRef]

87. Zhang, J.; Hu, Y.; Jiang, X.; Chen, S.; Meng, S.; Fu, X. Design of a direct Z-scheme photocatalyst: Preparation and characterization of Bi2O3/g-C3N4 with high visible light activity. J. Hazard. Mater. 2014, 280, 713-722. [CrossRef]

88. Mohamed, N.A.; Ullah, H.; Safaei, J.; Ismail, A.F.; Mohamad Noh, M.F.; Soh, M.F.; Ibrahim, M.A.; Ludin, N.A.; Mat Teridi, M.A. Efficient Photoelectrochemical Performance of $\gamma$ Irradiated g- $\mathrm{C}_{3} \mathrm{~N}_{4}$ and Its $\mathrm{g}^{-} \mathrm{C}_{3} \mathrm{~N}_{4} @ B i V \mathrm{~B}_{4}$ Heterojunction for Solar Water Splitting. J. Phys. Chem. C 2019, 123, 9013-9026. [CrossRef]

89. Wang, X.; Li, S.; Ma, Y.; Yu, H.; Yu, J. $\mathrm{H}_{2} \mathrm{WO}_{4} \cdot \mathrm{H}_{2} \mathrm{O} / \mathrm{Ag} / \mathrm{AgCl}$ composite nanoplates: A plasmonic Z-scheme visible-light photocatalyst. J. Phys. Chem. C 2011, 115, 14648-14655. [CrossRef]

90. Xie, X.; Wang, S.; Zhang, Y.; Ding, J.; Liu, Y.; Yan, Q.; Lu, S.; Li, B.; Liu, Y.; Cai, Q. Facile construction for new core-shell Z-scheme photocatalyst $\mathrm{GO} / \mathrm{AgI} / \mathrm{Bi}_{2} \mathrm{O}_{3}$ with enhanced visible-light photocatalytic activity. J. Colloid Interface Sci. 2021, 581, 148-158. [CrossRef]

91. Cui, Y.; Zhang, X.; Guo, R.; Zhang, H.; Li, B.; Xie, M.; Cheng, Q.; Cheng, X. Construction of $\mathrm{Bi}_{2} \mathrm{O}_{3} / \mathrm{g}_{-} \mathrm{C}_{3} \mathrm{~N}_{4}$ composite photocatalyst and its enhanced visible light photocatalytic performance and mechanism. Sep. Purif. Technol. 2018, 203, 301-309. [CrossRef]

92. Wu, T.; Zhou, X.; Zhang, H.; Zhong, X. $\mathrm{Bi}_{2} \mathrm{~S}_{3}$ nanostructures: A new photocatalyst. Nano Res. 2010, 3, 379-386. [CrossRef]

93. Zhang, H.; Huang, J.; Zhou, X.; Zhong, X. Single-crystal $\mathrm{Bi}_{2} \mathrm{~S}_{3}$ nanosheets growing via attachment-recrystallization of nanorods. Inorg. Chem. 2011, 50, 7729-7734. [CrossRef]

94. Chen, J.; Qin, S.; Song, G.; Xiang, T.; Xin, F.; Yin, X. Shape-controlled solvothermal synthesis of $\mathrm{Bi}_{2} \mathrm{~S}_{3}$ for photocatalytic reduction of $\mathrm{CO}_{2}$ to methyl formate in methanol. Dalton Trans. 2013, 42, 15133-15138. [CrossRef] [PubMed]

95. Kobasa, I.; Tarasenko, G. Photocatalysis of Reduction of the Dye Methylene Blue by $\mathrm{Bi}_{2} \mathrm{~S}_{3} /$ CdS Nanocomposites. Theor. Exp. Chem. 2002, 38, 255-258. [CrossRef]

96. Bessekhouad, Y.; Robert, D.; Weber, J. $\mathrm{Bi}_{2} \mathrm{~S}_{3} / \mathrm{TiO}_{2}$ and $\mathrm{CdS} / \mathrm{TiO}_{2}$ heterojunctions as an available configuration for photocatalytic degradation of organic pollutant. J. Photochem. Photobiol. A Chem. 2004, 163, 569-580. [CrossRef]

97. Zhang, Z.; Wang, W.; Wang, L.; Sun, S. Enhancement of visible-light photocatalysis by coupling with narrow-band-gap semiconductor: A case study on $\mathrm{Bi}_{2} \mathrm{~S}_{3} / \mathrm{Bi}_{2} \mathrm{WO}_{6}$. ACS Appl. Mater. Interfaces 2012, 4, 593-597. [CrossRef]

98. Lai, K.; Wei, W.; Dai, Y.; Zhang, R.; Huang, B. DFT calculations on structural and electronic properties of $\mathrm{Bi}_{2} \mathrm{MO}_{6}(\mathrm{M}=\mathrm{Cr}, \mathrm{Mo}, \mathrm{W})$. Rare Met. 2011, 30, 166-172. [CrossRef]

99. Chawla, H.; Chandra, A.; Ingole, P.P.; Garg, S. Recent advancements in enhancement of photocatalytic activity using bismuthbased metal oxides $\mathrm{Bi}_{2} \mathrm{MO}_{6}(\mathrm{M}=\mathrm{W}, \mathrm{Mo}, \mathrm{Cr})$ for environmental remediation and clean energy production. J. Ind. Eng. Chem. 2021, 95, 1-15. [CrossRef]

100. Xie, H.; Shen, D.; Wang, X.; Shen, G. Microwave hydrothermal synthesis and visible-light photocatalytic activity of $\gamma$-Bi2MoO6 nanoplates. Mater. Chem. Phys. 2008, 110, 332-336. [CrossRef]

101. Stelo, F.; Kublik, N.; Ullah, S.; Wender, H. Recent advances in $\mathrm{Bi}_{2} \mathrm{MoO}_{6}$ based Z-scheme heterojunctions for photocatalytic degradation of pollutants. J. Alloys Compd. 2020, 829, 154591. [CrossRef]

102. Murcia-López, S.; Hidalgo, M.C.; Navío, J.A. Degradation of rhodamine B/phenol mixtures in water by sun-like excitation of a $\mathrm{Bi}_{2} \mathrm{WO}_{6}-\mathrm{TiO}_{2}$ photocatalyst. Photochem. Photobiol. 2013, 89, 832-840. [CrossRef]

103. Fu, H.; Zhang, S.; Xu, T.; Zhu, Y.; Chen, J. Photocatalytic degradation of $\mathrm{RhB}$ by fluorinated $\mathrm{Bi}_{2} \mathrm{WO}_{6}$ and distributions of the intermediate products. Environ. Sci. Technol. 2008, 42, 2085-2091. [CrossRef] [PubMed]

104. Tang, J.; Zou, Z.; Ye, J. Efficient photocatalytic decomposition of organic contaminants over $\mathrm{CaBi}_{2} \mathrm{O}_{4}$ under visible-light irradiation Angew. Chem. Int. Ed. 2004, 43, 4463-4466. [CrossRef] [PubMed]

105. Huang, Y.; Ai, Z.; Ho, W.; Chen, M.; Lee, S. Ultrasonic spray pyrolysis synthesis of porous $\mathrm{Bi}_{2} \mathrm{WO}_{6}$ microspheres and their visible-light-induced photocatalytic removal of NO. J. Phys. Chem. C 2010, 114, 6342-6349. [CrossRef]

106. Zhang, L.-S.; Wong, K.-H.; Yip, H.-Y.; Hu, C.; Yu, J.C.; Chan, C.-Y.; Wong, P.-K. Effective photocatalytic disinfection of E. coli K-12 using $\mathrm{AgBr}^{-} \mathrm{Ag}^{-} \mathrm{Bi}_{2} \mathrm{WO}_{6}$ nanojunction system irradiated by visible light: The role of diffusing hydroxyl radicals. Environ. Sci. Technol. 2010, 44, 1392-1398. [CrossRef]

107. Zhang, Y.; Zhu, Y.; Yu, J.; Yang, D.; Ng, T.W.; Wong, P.K.; Jimmy, C.Y. Enhanced photocatalytic water disinfection properties of $\mathrm{Bi}_{2} \mathrm{MoO}_{6}-\mathrm{RGO}$ nanocomposites under visible light irradiation. Nanoscale 2013, 5, 6307-6310. [CrossRef] [PubMed]

108. Wang, P.; Ao, Y.; Wang, C.; Hou, J.; Qian, J. A one-pot method for the preparation of graphene-Bi ${ }_{2} \mathrm{MoO}_{6}$ hybrid photocatalysts that are responsive to visible-light and have excellent photocatalytic activity in the degradation of organic pollutants. Carbon 2012, 50, 5256-5264. [CrossRef]

109. Tian, G.; Chen, Y.; Zhou, J.; Tian, C.; Li, R.; Wang, C.; Fu, H. In situ growth of $\mathrm{Bi}_{2} \mathrm{MoO}_{6}$ on reduced graphene oxide nanosheets for improved visible-light photocatalytic activity. CrystEngComm 2014, 16, 842-849. [CrossRef] 
110. Zhao, Z.; Luo, W.; Li, Z.; Zou, Z. Density functional theory study of doping effects in monoclinic clinobisvanite BiVO 4 . Phys. Lett. A 2010, 374, 4919-4927. [CrossRef]

111. Gotić, M.; Musić, S.; Ivanda, M.; Šoufek, M.; Popović, S. Synthesis and characterisation of bismuth (III) vanadate. J. Mol. Struct. 2005, 744, 535-540. [CrossRef]

112. Kudo, A.; Omori, K.; Kato, H. A novel aqueous process for preparation of crystal form-controlled and highly crystalline $\mathrm{BiVO}_{4}$ powder from layered vanadates at room temperature and its photocatalytic and photophysical properties. J. Am. Chem. Soc. 1999, 121, 11459-11467. [CrossRef]

113. Ullah, H.; Tahir, A.A.; Bibi, S.; Mallick, T.K.; Karazhanov, S.Z. Electronic properties of $\beta$-TaON and its surfaces for solar water splitting. Appl. Catal. B 2018, 229, 24-31. [CrossRef]

114. Liu, J.; Wang, H.; Wang, S.; Yan, H. Hydrothermal preparation of BiVO 4 powders. Mater. Sci. Eng. B 2003, 104, 36-39. [CrossRef]

115. Zhang, Z.; Wang, W.; Shang, M.; Yin, W. Photocatalytic degradation of rhodamine B and phenol by solution combustion synthesized $\mathrm{BiVO}_{4}$ photocatalyst. Catal. Commun. 2010, 11, 982-986. [CrossRef]

116. Shang, M.; Wang, W.; Ren, J.; Sun, S.; Zhang, L. A novel $\mathrm{BiVO}_{4}$ hierarchical nanostructure: Controllable synthesis, growth mechanism, and application in photocatalysis. CrystEngComm 2010, 12, 1754-1758. [CrossRef]

117. Ng, Y.H.; Iwase, A.; Kudo, A.; Amal, R. Reducing graphene oxide on a visible-light $\mathrm{BiVO}_{4}$ photocatalyst for an enhanced photoelectrochemical water splitting. J. Phys. Chem. Lett. 2010, 1, 2607-2612. [CrossRef]

118. Su, J.; Guo, L.; Bao, N.; Grimes, C.A. Nanostructured $\mathrm{WO}_{3} / \mathrm{BiVO}_{4}$ heterojunction films for efficient photoelectrochemical water splitting. Nano Lett. 2011, 11, 1928-1933. [CrossRef]

119. Yang, J.; Wang, D.; Zhou, X.; Li, C. A theoretical study on the mechanism of photocatalytic oxygen evolution on $\mathrm{BiVO}_{4}$ in aqueous solution. Chem. A Eur. J. 2013, 19, 1320-1326. [CrossRef] [PubMed]

120. Booshehri, A.Y.; Goh, S.C.-K.; Hong, J.; Jiang, R.; Xu, R. Effect of depositing silver nanoparticles on $\mathrm{BiVO}_{4}$ in enhancing visible light photocatalytic inactivation of bacteria in water. J. Mater. Chem. A 2014, 2, 6209-6217. [CrossRef]

121. Wei, C.; Lin, W.Y.; Zainal, Z.; Williams, N.E.; Zhu, K.; Kruzic, A.P.; Smith, R.L.; Rajeshwar, K. Bactericidal activity of TiO 2 photocatalyst in aqueous media: Toward a solar-assisted water disinfection system. Environ. Sci. Technol. 1994, 28, 934-938. [CrossRef]

122. Bai, S.; Jiang, W.; Li, Z.; Xiong, Y. Surface and interface engineering in photocatalysis. ChemNanoMat 2015, 1, 223-239. [CrossRef]

123. Chen, F.; Yang, Q.; Wang, Y.; Zhao, J.; Wang, D.; Li, X.; Guo, Z.; Wang, H.; Deng, Y.; Niu, C. Novel ternary heterojunction photcocatalyst of Ag nanoparticles and g-C3N4 nanosheets co-modified BiVO4 for wider spectrum visible-light photocatalytic degradation of refractory pollutant. Appl. Catal. B Environ. 2017, 205, 133-147. [CrossRef]

124. Lin, X.; Xu, D.; Xi, Y.; Zhao, R.; Zhao, L.; Song, M.; Zhai, H.; Che, G.; Chang, L. Construction of leaf-like g-C $\mathrm{C}_{3} \mathrm{~N}_{4} / \mathrm{Ag} / \mathrm{BiVO}_{4}$ nanoheterostructures with enhanced photocatalysis performance under visible-light irradiation. Colloids Surf. A Physicochem. Eng. Asp. 2017, 513, 117-124. [CrossRef]

125. Ou, M.; Wan, S.; Zhong, Q.; Zhang, S.; Song, Y.; Guo, L.; Cai, W.; Xu, Y. Hierarchical Z-scheme photocatalyst of g-C $\mathrm{C}_{3} @$ $\mathrm{Ag} / \mathrm{BiVO}_{4}(040)$ with enhanced visible-light-induced photocatalytic oxidation performance. Appl. Catal. B Environ. 2018, 221, 97-107. [CrossRef]

126. Huang, W.L.; Zhu, Q. Electronic structures of relaxed BiOX (X= F, Cl, Br, I) photocatalysts. Comput. Mater. Sci. 2008, 43, 1101-1108. [CrossRef]

127. Li, H.; Long, B.; Ye, K.-H.; Cai, Y.; He, X.; Lan, Y.; Yang, Z.; Ji, H. A recyclable photocatalytic tea-bag-like device model based on ultrathin $\mathrm{Bi} / \mathrm{C} / \mathrm{BiOX}(\mathrm{X}=\mathrm{Cl}, \mathrm{Br})$ nanosheets. Appl. Surf. Sci. 2020, 515, 145967. [CrossRef]

128. Su, W.; Wang, J.; Huang, Y.; Wang, W.; Wu, L.; Wang, X.; Liu, P. Synthesis and catalytic performances of a novel photocatalyst BiOF. Scripta Mater. 2010, 62, 345-348. [CrossRef]

129. Zhang, X.; Ai, Z.; Jia, F.; Zhang, L. Generalized one-pot synthesis, characterization, and photocatalytic activity of hierarchical $\operatorname{BiOX}(X=\mathrm{Cl}, \mathrm{Br}, \mathrm{I})$ nanoplate microspheres. J. Phys. Chem. C. 2008, 112, 747-753. [CrossRef]

130. Zhang, M.; Yin, H.-F.; Yao, J.-C.; Arif, M.; Qiu, B.; Li, P.-F.; Liu, X.-H. All-solid-state Z-scheme BiOX (Cl, Br)-Au-CdS heterostructure: Photocatalytic activity and degradation pathway. Colloids Surf. A Physicochem. Eng. Asp. 2020, 602, 124778. [CrossRef]

131. Cheng, H.; Huang, B.; Dai, Y. Engineering BiOX (X = Cl, Br, I) nanostructures for highly efficient photocatalytic applications. Nanoscale 2014, 6, 2009-2026. [CrossRef]

132. GUI, M.-S.; WANG, P.-F.; YUAN, D.; Yang, Y.-K. Synthesis and visible-light photocatalytic activity of $\mathrm{Bi}_{2} \mathrm{WO}_{6} / \mathrm{g}^{-\mathrm{C} 3 N 4}$ composite photocatalysts. Chin. J. Inorg. Chem. 2013, 29, 2057-2064.

133. Jian, Z.; Yan, Z.; Yu-Hua, S.; Cun, L.; An-Jian, X. Flower-like $\mathrm{Bi}_{2} \mathrm{WO}_{6}$ porous microspheres: Assembly and photocatalytic performance. Chin. J. Inorg. Chem. 2012, 28, 739-744.

134. Zhang, X.; Chang, X.; Gondal, M.; Zhang, B.; Liu, Y.; Ji, G. Synthesis and photocatalytic activity of graphene/BiOBr composites under visible light. Appl. Surf. Sci. 2012, 258, 7826-7832. [CrossRef]

135. Ma, M.; Yang, Y.; Chen, Y.; Ma, Y.; Lyu, P.; Cui, A.; Huang, W.; Zhang, Z.; Li, Y.; Si, F. Photocatalytic degradation of MB dye by the magnetically separable 3D flower-like $\mathrm{Fe}_{3} \mathrm{O}_{4} / \mathrm{SiO}_{2} / \mathrm{MnO}_{2} / \mathrm{BiOBr}-\mathrm{Bi}$ photocatalyst. J. Alloys Compd. 2021, 861, 158256. [CrossRef]

136. Liu, T.; Zhang, Y.; Shi, Z.; Cao, W.; Zhang, L.; Liu, J.; Chen, Z. BiOBr/Ag/AgBr heterojunctions decorated carbon fiber cloth with broad-spectral photoresponse as filter-membrane-shaped photocatalyst for the efficient purification of flowing wastewater. $J$. Colloid Interface Sci. 2021, 587, 633-643. [CrossRef] [PubMed] 
137. Jianwei, C.; Jianwen, S.; Xu, W.; Haojie, C.; Minglai, F. Recent progress in the preparation and application of semiconductor/graphene composite photocatalysts. Chin. J. Catal. 2013, 34, 621-640.

138. Liu, W.; Cai, J.; Li, Z. Self-assembly of semiconductor nanoparticles/reduced graphene oxide (RGO) composite aerogels for enhanced photocatalytic performance and facile recycling in aqueous photocatalysis. ACS Sustain. Chem. Eng. 2015, 3, 277-282. [CrossRef]

139. Ibrahim, M.; Saeed, T.; Chu, Y.-M.; Ali, H.M.; Cheraghian, G.; Kalbasi, R. Comprehensive study concerned graphene nano-sheets dispersed in ethylene glycol: Experimental study and theoretical prediction of thermal conductivity. Powder Technol. 2021, 386, 51-59. [CrossRef]

140. Xue, Y.; Liang, W.; Feng, L.-J.; Li, C.-H. Preparation of Au/BiOBr/Graphene composite and its photocatalytic performance in phenol degradation under visible light. J. Fuel Chem. Technol. 2016, 44, 937-942.

141. Deng, F.; Zhang, Q.; Yang, L.; Luo, X.; Wang, A.; Luo, S.; Dionysiou, D.D. Visible-light-responsive graphene-functionalized Bi-bridge $\mathrm{Z}$-scheme black $\mathrm{BiOCl} / \mathrm{Bi}_{2} \mathrm{O}_{3}$ heterojunction with oxygen vacancy and multiple charge transfer channels for efficient photocatalytic degradation of 2-nitrophenol and industrial wastewater treatment. Appl. Catal. B Environ. 2018, 238, 61-69. [CrossRef]

142. Pan, C.; Zhu, Y. New type of $\mathrm{BiPO}_{4}$ oxy-acid salt photocatalyst with high photocatalytic activity on degradation of dye. Environ. Sci. Technol. 2010, 44, 5570-5574. [CrossRef]

143. Li, G.; Ding, Y.; Zhang, Y.; Lu, Z.; Sun, H.; Chen, R. Microwave synthesis of $\mathrm{BiPO}_{4}$ nanostructures and their morphologydependent photocatalytic performances. J. Colloid Interface Sci. 2011, 363, 497-503. [CrossRef]

144. Long, B.; Huang, J.; Wang, X. Photocatalytic degradation of benzene in gas phase by nanostructured BiPO 4 catalysts. Prog. Nat. Sci. Mater. Int. 2012, 22, 644-653. [CrossRef]

145. Ola, O.; Ullah, H.; Chen, Y.; Thummavichai, K.; Wang, N.; Zhu, Y. DFT and Experimental Studies of Iron Oxide-based Nanocomposites for Efficient Electrocatalysis. J. Mater. Chem. C 2021. [CrossRef]

146. Cao, J.; Xu, B.; Lin, H.; Chen, S. Highly improved visible light photocatalytic activity of $\mathrm{BiPO}_{4}$ through fabricating a novel p-n heterojunction $\mathrm{BiOI} / \mathrm{BiPO}_{4}$ nanocomposite. Chem. Eng. J. 2013, 228, 482-488. [CrossRef]

147. An, W.; Cui, W.; Liang, Y.; Hu, J.; Liu, L. Surface decoration of $\mathrm{BiPO}_{4}$ with $\mathrm{BiOBr}$ nanoflakes to build heterostructure photocatalysts with enhanced photocatalytic activity. Appl. Surf. Sci. 2015, 351, 1131-1139. [CrossRef]

148. Gao, E.; Wang, W. Role of graphene on the surface chemical reactions of $\mathrm{BiPO}_{4}-\mathrm{rGO}$ with low OH-related defects. Nanoscale 2013, 5, 11248-11256. [CrossRef]

149. Zou, X.; Dong, Y.; Zhang, X.; Cui, Y.; Ou, X.; Qi, X. The highly enhanced visible light photocatalytic degradation of gaseous o-dichlorobenzene through fabricating like-flowers $\mathrm{BiPO}_{4} / \mathrm{BiOBr}$ pn heterojunction composites. Appl. Surf. Sci. 2017, 391, 525-534. [CrossRef]

150. Shah, S.S.; Alfasane, M.A.; Bakare, I.A.; Aziz, M.A.; Yamani, Z.H. Polyaniline and heteroatoms-enriched carbon derived from Pithophora polymorpha composite for high performance supercapacitor. J. Energy Storage 2020, 30, 101562. [CrossRef]

151. Shah, S.S.; Cevik, E.; Aziz, M.A.; Qahtan, T.F.; Bozkurt, A.; Yamani, Z.H. Jute Sticks Derived and Commercially Available Activated Carbons for Symmetric Supercapacitors with Bio-electrolyte: A Comparative Study. Synth. Met. 2021, $77,116765$.

152. Taylor, P.; Sunder, S.; Lopata, V.J. Structure, spectra, and stability of solid bismuth carbonates. Can. J. Chem. 1984, 62, 2863-2873. [CrossRef]

153. Dong, F.; Zheng, A.; Sun, Y.; Fu, M.; Jiang, B.; Ho, W.-K.; Lee, S.; Wu, Z. One-pot template-free synthesis, growth mechanism and enhanced photocatalytic activity of monodisperse $(\mathrm{BiO})_{2} \mathrm{CO}_{3}$ hierarchical hollow microspheres self-assembled with singlecrystalline nanosheets. CrystEngComm 2012, 14, 3534-3544. [CrossRef]

154. Lin, K.; Qian, J.; ZhaO, Z.; Wu, G.; Wu, H. Synthesis of a carbon-loaded $\mathrm{Bi}_{2} \mathrm{O}_{2} \mathrm{CO}_{3} / \mathrm{TiO}_{2}$ photocatalyst with improved photocatalytic degradation of methyl orange dye. J. Nanosci. Nanotechnol. 2020, 20, 7653-7658. [CrossRef]

155. Chen, R.; So, M.H.; Yang, J.; Deng, F.; Che, C.-M.; Sun, H. Fabrication of bismuth subcarbonate nanotube arrays from bismuth citrate. Chem. Commun. 2006, 21, 2265-2267. [CrossRef] [PubMed]

156. Dong, F.; Sun, Y.; Fu, M.; Ho, W.-K.; Lee, S.C.; Wu, Z. Novel in situ N-doped $(\mathrm{BiO})_{2} \mathrm{CO}_{3}$ hierarchical microspheres self-assembled by nanosheets as efficient and durable visible light driven photocatalyst. Langmuir 2011, 28, 766-773. [CrossRef]

157. Bin Mohd Yusoff, A.R.; Mahata, A.; Vasilopoulou, M.; Ullah, H.; Hu, B.; da Silva, W.J.; Schneider, F.K.; Gao, P.; Ievlev, A.V.; Liu, Y. Observation of large Rashba spin-orbit coupling at room temperature in compositionally engineered perovskite single crystals and application in high performance photodetectors. Mater. Today 2021, in press.

158. Hasan, M.M.; Islam, T.; Imran, A.; Alqahtani, B.; Shah, S.S.; Mahfoz, W.; Karim, M.R.; Alharbi, H.F.; Aziz, M.A.; Ahammad, A.J.S. Mechanistic Insights of the Oxidation of Bisphenol A at Ultrasonication Assisted Polyaniline-Au Nanoparticles Composite for Highly Sensitive Electrochemical Sensor. Electrochim. Acta 2021, 374, 137968. [CrossRef]

159. Žerjav, G.; Djinović, P.; Pintar, A. $\mathrm{TiO}_{2}-\mathrm{Bi}_{2} \mathrm{O}_{3} /(\mathrm{BiO})_{2} \mathrm{CO}_{3}$-reduced graphene oxide composite as an effective visible light photocatalyst for degradation of aqueous bisphenol A solutions. Catal. Today 2018, 315, 237-246. [CrossRef]

160. Chang, X.; Huang, J.; Cheng, C.; Sui, Q.; Sha, W.; Ji, G.; Deng, S.; Yu, G. BiOX (X = Cl, Br, I) photocatalysts prepared using NaBiO3 as the Bi source: Characterization and catalytic performance. Catal. Commun. 2010, 11, 460-464. [CrossRef]

161. Takei, T.; Haramoto, R.; Dong, Q.; Kumada, N.; Yonesaki, Y.; Kinomura, N.; Mano, T.; Nishimoto, S.; Kameshima, Y.; Miyake, M. Photocatalytic activities of various pentavalent bismuthates under visible light irradiation. J. Solid State Chem. 2011, 184, 2017-2022. [CrossRef] 
162. Ramachandran, R.; Sathiya, M.; Ramesha, K.; Prakash, A.; Madras, G.; Shukla, A. Photocatalytic properties of $\mathrm{KBiO}_{3}$ and $\mathrm{LiBiO}_{3}$ with tunnel structures. J. Chem. Sci. 2011, 123, 517-524. [CrossRef]

163. Kako, T.; Zou, Z.; Katagiri, M.; Ye, J. Decomposition of organic compounds over $\mathrm{NaBiO}_{3}$ under visible light irradiation. Chem. Mater. 2007, 19, 198-202. [CrossRef]

164. Yu, X.; Zhou, J.; Wang, Z.; Cai, W. Preparation of visible light-responsive AgBiO3 bactericide and its control effect on the Microcystis aeruginosa. J. Photochem. Photobiol. B Biol. 2010, 101, 265-270. [CrossRef]

165. Chang, X.; Huang, J.; Cheng, C.; Sha, W.; Li, X.; Ji, G.; Deng, S.; Yu, G. Photocatalytic decomposition of 4-t-octylphenol over $\mathrm{NaBiO} 3$ driven by visible light: Catalytic kinetics and corrosion products characterization. J. Hazard. Mater. 2010, 173, 765-772. [CrossRef]

166. Wu, Q.; Xu, Y.; Yao, Z.; Liu, A.; Shi, G. Supercapacitors based on flexible graphene/polyaniline nanofiber composite films. ACS Nano 2010, 4, 1963-1970. [CrossRef]

167. Ashraf, M.; Shah, S.S.; Khan, I.; Aziz, M.A.; Ullah, N.; Khan, M.; Adil, S.F.; Liaqat, Z.; Usman, M.; Tremel, W.; et al. A HighPerformance Asymmetric Supercapacitor Based on Tungsten Oxide Nanoplates and Highly Reduced Graphene Oxide Electrodes. Chem. Eur. J. 2021, in press. [CrossRef]

168. Hayat, K.; Shah, S.S.; Yousaf, M.; Iqbal, M.J.; Ali, M.; Ali, S.; Ajmal, M.; Iqbal, Y. Processing, device fabrication and electrical characterization of $\mathrm{LaMnO}_{3}$ nanofibers. Mater. Sci. Semicond. Process. 2016, 41, 364-369. [CrossRef]

169. Hayat, K.; Shah, S.S.; Ali, S.; Shah, S.K.; Iqbal, Y.; Aziz, M.A. Fabrication and characterization of $\mathrm{Pb}\left(\mathrm{Zr}_{0.5} \mathrm{Ti}_{0.5}\right) \mathrm{O}_{3}$ nanofibers for nanogenerator applications. J. Mater. Sci. Mater. Electron. 2020, 31, 15859-15874. [CrossRef]

170. Shah, S.S.; Hayat, K.; Ali, S.; Rasool, K.; Iqbal, Y. Conduction mechanisms in lanthanum manganite nanofibers. Mater. Sci. Semicond. Process. 2019, 90, 65-71. [CrossRef]

171. Liang, Y.; Wang, H.; Casalongue, H.S.; Chen, Z.; Dai, H. TiO 2 nanocrystals grown on graphene as advanced photocatalytic hybrid materials. Nano Res. 2010, 3, 701-705. [CrossRef]

172. Velasco-Hernández, A.; Esparza-Muñoz, R.; de Moure-Flores, F.; Santos-Cruz, J.; Mayén-Hernández, S. Synthesis and characterization of graphene oxide- $\mathrm{TiO}_{2}$ thin films by sol-gel for photocatalytic applications. Mater. Sci. Semicond. Process. 2020, $114,105082$. [CrossRef]

173. Pei, C.; Zhu, J.-H.; Xing, F. Photocatalytic property of cement mortars coated with graphene/TiO 2 nanocomposites synthesized via sol-gel assisted electrospray method. J. Clean. Prod. 2021, 279, 123590. [CrossRef]

174. Yang, S.; Zhang, L.; Shao, C.; Li, X.; Li, X.; Liu, S.; Tao, R.; Liu, Y. Facile preparation of flexible polyacrylonitrile/BiOCl/BiOI nanofibers via SILAR method for effective floating photocatalysis. J. Sol-Gel Sci. Technol. 2021, 97, 610-621. [CrossRef]

175. Pei, C.C.; Lo, K.K.S.; Leung, W.W.-F. Titanium-zinc-bismuth oxides-graphene composite nanofibers as high-performance photocatalyst for gas purification. Sep. Purif. Technol. 2017, 184, 205-212. [CrossRef]

176. Liu, H.; Mei, H.; Miao, N.; Pan, L.; Jin, Z.; Zhu, G.; Gao, J.; Wang, J. Synergistic photocatalytic NO removal of oxygen vacancies and metallic bismuth on Bi12TiO20 nanofibers under visible light irradiation. Chem. Eng. J. 2021, 414, 128748. [CrossRef]

177. Selvaraj, R.; Qi, K.; Al-Kindy, S.M.; Sillanpää, M.; Kim, Y.; Tai, C.-W. A simple hydrothermal route for the preparation of HgS nanoparticles and their photocatalytic activities. RSC Adv. 2014, 4, 15371-15376. [CrossRef]

178. Zhu, P.; Chen, Y.; Duan, M.; Ren, Z.; Hu, M. Construction and mechanism of a highly efficient and stable Z-scheme $\mathrm{Ag}_{3} \mathrm{PO}_{4} /$ reduced graphene oxide $/ \mathrm{Bi}_{2} \mathrm{MoO}_{6}$ visible-light photocatalyst. Catal. Sci. Technol. 2018, 8, 3818-3832. [CrossRef]

179. Wang, J.; Yu, X.; Fu, X.; Zhu, Y.; Zhang, Y. Accelerating carrier separation of $\mathrm{Ag}_{3} \mathrm{PO}_{4}$ via synergetic effect of PANI and rGO for enhanced photocatalytic performance towards ciprofloxacin. Mater. Sci. Semicond. Process. 2021, 121, 105329. [CrossRef]

180. Lv, H.; Liu, Y.; Tang, H.; Zhang, P.; Wang, J. Synergetic effect of $\mathrm{MoS}_{2}$ and graphene as cocatalysts for enhanced photocatalytic activity of $\mathrm{BiPO}_{4}$ nanoparticles. Appl. Surf. Sci. 2017, 425, 100-106. [CrossRef]

181. Ge, L.; Li, H.; Du, X.; Zhu, M.; Chen, W.; Shi, T.; Hao, N.; Liu, Q.; Wang, K. Facile one-pot synthesis of visible light-responsive $\mathrm{BiPO} /$ /nitrogen doped graphene hydrogel for fabricating label-free photoelectrochemical tetracycline aptasensor. Biosens. Bioelectron. 2018, 111, 131-137. [CrossRef]

182. Qian, J.; Yang, Z.; Wang, C.; Wang, K.; Liu, Q.; Jiang, D.; Yan, Y.; Wang, K. One-pot synthesis of $\mathrm{BiPO}_{4}$ functionalized reduced graphene oxide with enhanced photoelectrochemical performance for selective and sensitive detection of chlorpyrifos. J. Mater. Chem. A 2015, 3, 13671-13678. [CrossRef]

183. Wang, C.; Zhang, G.; Zhang, C.; Wu, M.; Yan, M.; Fan, W.; Shi, W. A facile one-step solvothermal synthesis of bismuth phosphate-graphene nanocomposites with enhanced photocatalytic activity. J. Colloid Interface Sci. 2014, 435, 156-163. [CrossRef]

184. Xiao, J.; Zhang, J.; Liu, W.; Huang, T.; Qu, Y.; Chen, H.; Lin, Z. Construction of $\mathrm{rGO} / \mathrm{Bi}_{2} \mathrm{MoO}_{6} 2 \mathrm{D} / 2 \mathrm{D}$ nanocomposites for enhancement visible light-driven photocatalytic reduction of $\mathrm{Cr}$ (VI). Mater. Res. Express 2018, 5, 115031. [CrossRef]

185. Ramanathan, T.; Abdala, A.; Stankovich, S.; Dikin, D.; Herrera-Alonso, M.; Piner, R.; Adamson, D.; Schniepp, H.; Chen, X.; Ruoff, R. Functionalized graphene sheets for polymer nanocomposites. Nat. Nanotechnol. 2008, 3, 327. [CrossRef] [PubMed]

186. Rani, E.; Talebi, P.; Cao, W.; Huttula, M.; Singh, H. Harnessing photo/electro-catalytic activity via nano-junctions in ternary nanocomposites for clean energy. Nanoscale 2020, 12, 23461-23479. [CrossRef] [PubMed]

187. Liu, M.; Xue, X.; Yu, S.; Wang, X.; Hu, X.; Tian, H.; Chen, H.; Zheng, W. Improving Photocatalytic Performance from Bi 2 WO $6 @$ MoS 2/graphene Hybrids via Gradual Charge Transferred Pathway. Sci. Rep. 2017, 7, 3637. [CrossRef] 
188. Zou, J.-P.; Ma, J.; Huang, Q.; Luo, S.-L.; Yu, J.; Luo, X.-B.; Dai, W.-L.; Sun, J.; Guo, G.-C.; Au, C.-T. Graphene oxide as structure-directing and morphology-controlling agent for the syntheses of heterostructured graphene- $\mathrm{Bi}_{2} \mathrm{MoO}_{6} / \mathrm{Bi}_{3.64} \mathrm{Mo}_{0.36} \mathrm{O}_{6.55}$ composites with high photocatalytic activity. Appl. Catal. B Environ. 2014, 156, 447-455. [CrossRef]

189. Wang, L.; Sun, B.; Wang, W.; Feng, L.; Li, Q.; Li, C. Modification of $\mathrm{Bi}_{2} \mathrm{WO}_{6}$ composites with $\mathrm{rGO}$ for enhanced visible light driven NO removal. Asia-Pac. J. Chem. Eng. 2017, 12, 121-127. [CrossRef]

190. Du, J.; Lai, X.; Yang, N.; Zhai, J.; Kisailus, D.; Su, F.; Wang, D.; Jiang, L. Hierarchically ordered macro- mesoporous TiO $2-$ graphene composite films: Improved mass transfer, reduced charge recombination, and their enhanced photocatalytic activities. ACS Nano 2010, 5, 590-596. [CrossRef]

191. Levin, A.; Hakala, T.A.; Schnaider, L.; Bernardes, G.J.; Gazit, E.; Knowles, T.P. Biomimetic peptide self-assembly for functional materials. Nat. Rev. Chem. 2020, 4, 615-634. [CrossRef]

192. Usman, M.; Ali, M.; Al-Maythalony, B.A.; Ghanem, A.S.; Saadi, O.W.; Ali, M.; Jafar Mazumder, M.A.; Abdel-Azeim, S.; Habib, M.A.; Yamani, Z.H.; et al. Highly Efficient Permeation and Separation of Gases with Metal-Organic Frameworks Confined in Polymeric Nanochannels. ACS Appl. Mater. Interfaces 2020, 12, 49992-50001. [CrossRef]

193. Wang, D.; Kou, R.; Choi, D.; Yang, Z.; Nie, Z.; Li, J.; Saraf, L.V.; Hu, D.; Zhang, J.; Graff, G.L. Ternary self-assembly of ordered metal oxide- graphene nanocomposites for electrochemical energy storage. ACS Nano 2010, 4, 1587-1595. [CrossRef] [PubMed]

194. Raizada, P.; Kumar, A.; Hasija, V.; Singh, P.; Thakur, V.K.; Khan, A.A.P. An overview of converting reductive photocatalyst into all solid-state and direct Z-scheme system for water splitting and $\mathrm{CO}_{2}$ reduction. J. Ind. Eng. Chem. 2020, 93, 1-27. [CrossRef]

195. Yang, J.; Wang, X.; Zhao, X.; Dai, J.; Mo, S. Synthesis of uniform $\mathrm{Bi}_{2} \mathrm{WO}_{6}$-reduced graphene oxide nanocomposites with significantly enhanced photocatalytic reduction activity. J. Phys. Chem. C. 2015, 119, 3068-3078. [CrossRef]

196. Lv, H.; Shen, X.; Ji, Z.; Qiu, D.; Zhu, G.; Bi, Y. Synthesis of graphene oxide- $\mathrm{BiPO}_{4}$ composites with enhanced photocatalytic properties. Appl. Surf. Sci. 2013, 284, 308-314. [CrossRef]

197. Yan, J.; Fan, Z.; Wei, T.; Qian, W.; Zhang, M.; Wei, F. Fast and reversible surface redox reaction of graphene-MnO ${ }_{2}$ composites as supercapacitor electrodes. Carbon 2010, 48, 3825-3833. [CrossRef]

198. Yan, J.; Wei, T.; Qiao, W.; Shao, B.; Zhao, Q.; Zhang, L.; Fan, Z. Rapid microwave-assisted synthesis of graphene nanosheet/Co ${ }_{3} \mathrm{O}_{4}$ composite for supercapacitors. Electrochim. Acta 2010, 55, 6973-6978. [CrossRef]

199. Hu, C.; Lu, T.; Chen, F.; Zhang, R. A brief review of graphene-metal oxide composites synthesis and applications in photocatalysis. J. Chin. Adv. Mater. Soc. 2013, 1, 21-39. [CrossRef]

200. Meng, X.; Zhang, Z. $\mathrm{Bi}_{2} \mathrm{MoO}_{6}$ co-modified by reduced graphene oxide and palladium (Pd2+ and Pd0) with enhanced photocatalytic decomposition of phenol. Appl. Catal. B Environ. 2017, 209, 383-393. [CrossRef]

201. Yao, Y.; Liang, J.; Wei, Y.; Zheng, X.; Xu, X.; He, G.; Chen, H. One-pot synthesis of visible-light-driven photocatalyst for degradation of Rhodamine B: Graphene based bismuth/bismuth(III) oxybromide. Mater. Lett. 2019, 240, 246-249. [CrossRef]

202. Li, K.; Chen, P.; Li, J.; Sun, Y.; Chu, Y.; Dong, F. Enhanced plasmonic photocatalytic disinfection on noble-metal-free bismuth nanospheres/graphene nanocomposites. Catal. Sci. Technol. 2018, 8, 4600-4603. [CrossRef]

203. Liu, F.-Y.; Dai, Y.-M.; Chen, F.-H.; Chen, C.-C. Lead bismuth oxybromide/graphene oxide: Synthesis, characterization, and photocatalytic activity for removal of carbon dioxide, crystal violet dye, and 2-hydroxybenzoic acid. J. Colloid Interface Sci. 2020, 562, 112-124. [CrossRef]

204. Sekar, K.; Kassam, A.; Bai, Y.; Coulson, B.; Li, W.; Douthwaite, R.E.; Sasaki, K.; Lee, A.F. Hierarchical bismuth vanadate/reduced graphene oxide composite photocatalyst for hydrogen evolution and bisphenol A degradation. Appl. Mater. Today 2021, 22, 100963. [CrossRef]

205. Sajid, M.M.; Shad, N.A.; Javed, Y.; Khan, S.B.; Zhang, Z.; Amin, N. Study of the interfacial charge transfer in bismuth vanadate/reduce graphene oxide $\left(\mathrm{BiVO}_{4} / \mathrm{rGO}\right)$ composite and evaluation of its photocatalytic activity. Res. Chem. Intermed. 2020, 46, 1201-1215. [CrossRef]

206. Dixit, T.K.; Sharma, S.; Sinha, A.S.K. Development of heterojunction in N-rGO supported bismuth ferrite photocatalyst for degradation of Rhodamine B. Inorg. Chem. Commun. 2020, 117, 107945. [CrossRef]

207. Faghihi-Zarandi, A.; Rakhtshah, J.; Bahrami Yarahmadi, B.; Shirkhanloo, H. A rapid removal of xylene vapor from environmental air based on bismuth oxide coupled to heterogeneous graphene/graphene oxide by UV photo-catalectic degradation-adsorption procedure. J. Environ. Chem. Eng. 2020, 8, 104193. [CrossRef]

208. Kumar, S.; Karfa, P.; Majhi, K.C.; Madhuri, R. Photocatalytic, fluorescent $\mathrm{BiPO}_{4} @$ Graphene oxide based magnetic molecularly imprinted polymer for detection, removal and degradation of ciprofloxacin. Mater. Sci. Eng. C 2020, 111, 110777. [CrossRef] [PubMed]

209. Bai, S.; Sun, L.; Sun, J.; Han, J.; Zhang, K.; Li, Q.; Luo, R.; Li, D.; Chen, A. Pine dendritic bismuth vanadate loaded on reduced graphene oxide for detection of low concentration triethylamine. J. Colloid Interface Sci. 2021, 587, 183-191. [CrossRef]

210. Buliyaminu, I.A.; Aziz, M.A.; Shah, S.S.; Mohamedkhair, A.K.; Yamani, Z.H. Preparation of nano-Co $\mathrm{O}_{4}$-coated Albizia proceraderived carbon by direct thermal decomposition method for electrochemical water oxidation. Arab. J. Chem. 2020, 13, 4785-4796. [CrossRef]

211. Shah, S.S.; Aziz, M.A.; Mohamedkhair, A.K.; Qasem, M.A.A.; Hakeem, A.S.; Nazal, M.K.; Yamani, Z.H. Preparation and characterization of manganese oxide nanoparticles-coated Albizia procera derived carbon for electrochemical water oxidation. J. Mater. Sci. Mater. Electron. 2019, 30, 16087-16098. [CrossRef] 
212. Yaqoob, L.; Noor, T.; Iqbal, N.; Nasir, H.; Sohail, M.; Zaman, N.; Usman, M. Nanocomposites of cobalt benzene tricarboxylic acid MOF with rGO: An efficient and robust electrocatalyst for oxygen evolution reaction (OER). Renew. Energy 2020, 156, 1040-1054. [CrossRef]

213. Ullah, H.; Loh, A.; Trudgeon, D.P.; Li, X. Density Functional Theory Study of NiFeCo Trinary Oxy-Hydroxides for an Efficient and Stable Oxygen Evolution Reaction Catalyst. ACS omega 2020, 5, 20517-20524. [CrossRef]

214. Mahfoz, W.; Aziz, M.A.; Shah, S.S.; Al-Betar, A.-R. Enhanced oxygen evolution via electrochemical water oxidation using conducting polymer and nanoparticle composites. Chem. Asian J. 2020, 15, 4358-4367. [CrossRef] [PubMed]

215. Deb Nath, N.C.; Shah, S.S.; Qasem, M.A.A.; Zahir, M.H.; Aziz, M.A. Defective Carbon Nanosheets Derived from Syzygium cumini Leaves for Electrochemical Energy-Storage. ChemistrySelect 2019, 4, 9079-9083. [CrossRef]

216. Fujishima, A.; Honda, K. Electrochemical photolysis of water at a semiconductor electrode. Nature 1972, 238, 37. [CrossRef]

217. Xia, Y.; Li, Q.; Wu, X.; Lv, K.; Tang, D.; Li, M. Facile synthesis of CNTs/CaIn2S4 composites with enhanced visible-light photocatalytic performance. Appl. Surf. Sci. 2017, 391, 565-571. [CrossRef]

218. Qi, K.; Xie, Y.; Wang, R.; Liu, S.-y.; Zhao, Z. Electroless plating Ni-P cocatalyst decorated g-C3N4 with enhanced photocatalytic water splitting for $\mathrm{H} 2$ generation. Appl. Surf. Sci. 2019, 466, 847-853. [CrossRef]

219. Qi, K.; Liu, S.-y.; Qiu, M. Photocatalytic performance of $\mathrm{TiO}_{2}$ nanocrystals with/without oxygen defects. Chin. J. Catal. 2018, 39, 867-875. [CrossRef]

220. Wang, G.; Long, X.; Qi, K.; Dang, S.; Zhong, M.; Xiao, S.; Zhou, T. Two-dimensional CdS/g- ${ }_{6} \mathrm{~N}_{6}$ heterostructure used for visible light photocatalysis. Appl. Surf. Sci. 2019, 471, 162-167. [CrossRef]

221. Meng, J.; Cui, Z.; Yang, X.; Zhu, S.; Li, Z.; Qi, K.; Zheng, L.; Liang, Y. Cobalt-iron (oxides) water oxidation catalysts: Tracking catalyst redox states and reaction dynamic mechanism. J. Catal. 2018, 365, 227-237. [CrossRef]

222. Wei, Y.; Meng, W.; Wang, Y.; Gao, Y.; Qi, K.; Zhang, K. Fast hydrogen generation from $\mathrm{NaBH}_{4}$ hydrolysis catalyzed by nanostructured Co-Ni-B catalysts. Int. J. Hydrog. Energy 2017, 42, 6072-6079. [CrossRef]

223. Timmerberg, S.; Kaltschmitt, M.; Finkbeiner, M. Hydrogen and hydrogen-derived fuels through methane decomposition of natural gas-GHG emissions and costs. Energy Convers. Manag. X 2020, 7, 100043. [CrossRef]

224. Zhang, N.; Zhang, Y.; Xu, Y.-J. Recent progress on graphene-based photocatalysts: Current status and future perspectives. Nanoscale 2012, 4, 5792-5813. [CrossRef]

225. Singh, P.; Shandilya, P.; Raizada, P.; Sudhaik, A.; Rahmani-Sani, A.; Hosseini-Bandegharaei, A. Review on various strategies for enhancing photocatalytic activity of graphene based nanocomposites for water purification. Arab. J. Chem. 2020, 13, 3498-3520. [CrossRef]

226. Soltani, T.; Tayyebi, A.; Lee, B.-K. Efficient promotion of charge separation with reduced graphene oxide $(\mathrm{rGO}) \mathrm{in} \mathrm{BiVO}_{4} / \mathrm{rGO}$ photoanode for greatly enhanced photoelectrochemical water splitting. Solar Energy Mater. Solar Cells 2018, 185, 325-332. [CrossRef]

227. Ng, Y.H.; Iwase, A.; Bell, N.J.; Kudo, A.; Amal, R. Semiconductor/reduced graphene oxide nanocomposites derived from photocatalytic reactions. Catal. Today 2011, 164, 353-357. [CrossRef]

228. Iwase, A.; Ng, Y.H.; Ishiguro, Y.; Kudo, A.; Amal, R. Reduced Graphene Oxide as a Solid-State Electron Mediator in Z-Scheme Photocatalytic Water Splitting under Visible Light. J. Am. Chem. Soc. 2011, 133, 11054-11057. [CrossRef]

229. Ren, Y.; Zeng, D.; Ong, W.-J. Interfacial engineering of graphitic carbon nitride $\left(\mathrm{g}_{-} \mathrm{C}_{3} \mathrm{~N}_{4}\right)$-based metal sulfide heterojunction photocatalysts for energy conversion: A review. Chin. J. Catal. 2019, 40, 289-319. [CrossRef]

230. Yaw, C.S.; Ng, W.C.; Ruan, Q.; Tang, J.; Soh, A.K.; Chong, M.N. Tuning of reduced graphene oxide thin film as an efficient electron conductive interlayer in a proven heterojunction photoanode for solar-driven photoelectrochemical water splitting. J. Alloys Compd. 2020, 817, 152721. [CrossRef]

231. Helal, A.; Cordova, K.E.; Arafat, M.E.; Usman, M.; Yamani, Z.H. Defect-engineering a metal-organic framework for $\mathrm{CO}_{2}$ fixation in the synthesis of bioactive oxazolidinones. Inorg. Chem. Front. 2020, 7, 3571-3577. [CrossRef]

232. Garba, M.D.; Usman, M.; Khan, S.; Shehzad, F.; Galadima, A.; Ehsan, M.F.; Ghanem, A.S.; Humayun, M. CO 2 towards fuels: A review of catalytic conversion of carbon dioxide to hydrocarbons. J. Environ. Chem. Eng. 2021, 9, 104756. [CrossRef]

233. Helal, A.; Usman, M.; Arafat, M.E.; Abdelnaby, M.M. Allyl functionalized UiO-66 metal-organic framework as a catalyst for the synthesis of cyclic carbonates by $\mathrm{CO}_{2}$ cycloaddition. J. Ind. Eng. Chem. 2020, 89, 104-110. [CrossRef]

234. Yu, J.; Low, J.; Xiao, W.; Zhou, P.; Jaroniec, M. Enhanced photocatalytic $\mathrm{CO}_{2}$-reduction activity of anatase $\mathrm{TiO}_{2}$ by coexposed $\{001\}$ and $\{101\}$ facets. J. Am. Chem. Soc. 2014, 136, 8839-8842. [CrossRef]

235. Din, I.U.; Usman, M.; Khan, S.; Helal, A.; Alotaibi, M.A.; Alharthi, A.I.; Centi, G. Prospects for a green methanol thermo-catalytic process from $\mathrm{CO}_{2}$ by using MOFs based materials: A mini-review. J. $\mathrm{CO}_{2}$ Util. 2021, 43, 101361. [CrossRef]

236. Kim, H.P.; Vasilopoulou, M.; Ullah, H.; Bibi, S.; Gavim, A.E.X.; Macedo, A.G.; da Silva, W.J.; Schneider, F.K.; Tahir, A.A.; Teridi, M.A.M. A hysteresis-free perovskite transistor with exceptional stability through molecular cross-linking and amine-based surface passivation. Nanoscale 2020, 12, 7641-7650. [CrossRef] [PubMed]

237. Sun, J.; Zheng, W.; Lyu, S.; He, F.; Yang, B.; Li, Z.; Lei, L.; Hou, Y. Bi/ $\mathrm{Bi}_{2} \mathrm{O}_{3}$ nanoparticles supported on N-doped reduced graphene oxide for highly efficient $\mathrm{CO}_{2}$ electroreduction to formate. Chin. Chem. Lett. 2020, 31, 1415-1421. [CrossRef]

238. Sun, S.; Watanabe, M.; Wang, P.; Ishihara, T. Synergistic Enhancement of $\mathrm{H}_{2}$ and $\mathrm{CH}_{4}$ Evolution by $\mathrm{CO}_{2} \mathrm{Photoreduction} \mathrm{in}$ Water with Reduced Graphene Oxide-Bismuth Monoxide Quantum Dot Catalyst. ACS Appl. Energy Mater. 2019, 2, $2104-2112$. [CrossRef] 
239. Bian, J.; Feng, J.; Zhang, Z.; Sun, J.; Chu, M.; Sun, L.; Li, X.; Tang, D.; Jing, L. Graphene-modulated assembly of zinc phthalocyanine on $\mathrm{BiVO} 4$ nanosheets for efficient visible-light catalytic conversion of $\mathrm{CO}_{2}$. Chem. Commun. 2020, 56, 4926-4929. [CrossRef]

240. Yang, X.; Deng, P.; Liu, D.; Zhao, S.; Li, D.; Wu, H.; Ma, Y.; Xia, B.Y.; Li, M.; Xiao, C.; et al. Partial sulfuration-induced defect and interface tailoring on bismuth oxide for promoting electrocatalytic $\mathrm{CO}_{2}$ reduction. J. Mater. Chem. A 2020, 8, 2472-2480. [CrossRef]

241. Li, M.; Zhang, L.; Fan, X.; Zhou, Y.; Wu, M.; Shi, J. Highly selective $\mathrm{CO}_{2}$ photoreduction to CO over $\mathrm{gC}_{3} \mathrm{~N}_{4} / \mathrm{Bi}_{2} \mathrm{WO}_{6}$ composites under visible light. J. Mater. Chem. A 2015, 3, 5189-5196. [CrossRef]

242. Mulik, B.B.; Bankar, B.D.; Munde, A.V.; Biradar, A.V.; Sathe, B.R. Bismuth-Oxide-Decorated Graphene Oxide Hybrids for Catalytic and Electrocatalytic Reduction of $\mathrm{CO}_{2}$. Chem. Eur. J. 2020, 26, 8801-8809. [CrossRef]

243. Chen, L.; Zhang, M.; Yang, J.; Li, Y.; Sivalingam, Y.; Shi, Q.; Xie, M.; Han, W. Synthesis of BiVO 4 quantum dots/reduced graphene oxide composites for $\mathrm{CO}_{2}$ reduction. Mater. Sci. Semicond. Process. 2019, 102, 104578. [CrossRef]

244. Dalton, J.S.; Janes, P.A.; Jones, N.; Nicholson, J.A.; Hallam, K.R.; Allen, G.C. Photocatalytic oxidation of $\mathrm{NO}_{\mathrm{x}}$ gases using TiO 2 : A surface spectroscopic approach. Environ. Pollut. 2002, 120, 415-422. [CrossRef]

245. Lasek, J.; Yu, Y.-H.; Wu, J.C. Removal of NOx by photocatalytic processes. J. Photochem. Photobiol. C Photochem. Rev. 2013, 14, 29-52. [CrossRef]

246. Jafar Mazumder, M.A.; Raja, P.H.; Isloor, A.M.; Usman, M.; Chowdhury, S.H.; Ali, S.A.; Inamuddin; Al-Ahmed, A. Assessment of sulfonated homo and co-polyimides incorporated polysulfone ultrafiltration blend membranes for effective removal of heavy metals and proteins. Sci. Rep. 2020, 10, 7049. [CrossRef]

247. Ghazi, Z.A.; Khattak, A.M.; Iqbal, R.; Ahmad, R.; Khan, A.A.; Usman, M.; Nawaz, F.; Ali, W.; Felegari, Z.; Jan, S.U.; et al. Adsorptive removal of $\mathrm{Cd}^{2+}$ from aqueous solutions by a highly stable covalent triazine-based framework. New J. Chem. 2018, 42, 10234-10242. [CrossRef]

248. Thurston, G.D. Outdoor Air Pollution: Sources, Atmospheric Transport, and Human Health Effects. In International Encyclopedia of Public Health; Heggenhougen, H.K., Ed.; Academic Press: Oxford, UK, 2008; pp. 700-712.

249. Kang, S.B.; Karinshak, K.; Chen, P.W.; Golden, S.; Harold, M.P. Coupled methane and NOx conversion on Pt+Pd/Al2O3 monolith: Conversion enhancement through feed modulation and Mn0.5Fe2.5O4 spinel addition. Catal. Today 2021, 360, 284-293. [CrossRef]

250. Newton, M.A.; Dent, A.J.; Diaz-Moreno, S.; Fiddy, S.G.; Evans, J. Rapid phase fluxionality as the determining factor in activity and selectivity of highly dispersed, Rh/Al2O3 in deNOx catalysis. Angew. Chem. Int. Ed. 2002, 41, 2587-2589. [CrossRef]

251. Trichard, J. Current tasks and challenges for exhaust after-treatment research: An industrial viewpoint. Stud. Surf. Sci. Catal. 2007, 171, 211-233.

252. Yamashita, H.; Ichihashi, Y.; Anpo, M.; Hashimoto, M.; Louis, C.; Che, M. Photocatalytic decomposition of NO at 275 K on titanium oxides included within Y-zeolite cavities: The structure and role of the active sites. J. Phys. Chem. 1996, 100, 16041-16044. [CrossRef]

253. Yamashita, H.; Ichihashi, Y.; Zhang, S.G.; Matsumura, Y.; Souma, Y.; Tatsumi, T.; Anpo, M. Photocatalytic decomposition of NO at $275 \mathrm{~K}$ on titanium oxide catalysts anchored within zeolite cavities and framework. Appl. Surf. Sci. 1997, 121, 305-309. [CrossRef]

254. Wojtas, J.; Bielecki, Z.; Stacewicz, T.; Mikolajczyk, J.; Medrzycki, R.; Rutecka, B. Application of Quantum Cascade Lasers in Nitric Oxide and Nitrous Oxide Detection. Acta Phys. Pol. A. 2011, 120. [CrossRef]

255. Tuazon, E.C.; Winer, A.M.; Graham, R.A.; Schmid, J.P.; Pitts Jr, J.N. Fourier transform infrared detection of nitramines in irradiated amine-nitrogen oxides (NOx) systems. Environ. Sci. Technol. 1978, 12, 954-958. [CrossRef]

256. McClenny, W.A.; Williams, E.J.; Cohen, R.C.; Stutz, J. Preparing to measure the effects of the NOX SIP Call-methods for ambient air monitoring of NO, NO2, NOY, and individual NOZ species. J. Air Waste Manag. Assoc. 2002, 52, 542-562. [CrossRef]

257. Pijolat, C.; Pupier, C.; Testud, C.; Lalauze, R.; Montanaro, L.; Negro, A.; Malvicino, C. Electrochemical sensors for CO/NO x detection in automotive applications. J. Electroceram. 1998, 2, 181-191. [CrossRef]

258. Anufriev, I.S. Review of water/steam addition in liquid-fuel combustion systems for NOx reduction: Waste-to-energy trends. Renew. Sust. Energ. Rev. 2021, 138, 110665. [CrossRef]

259. Atkinson, J.D.; Zhang, Z.; Yan, Z.; Rood, M.J. Evolution and impact of acidic oxygen functional groups on activated carbon fiber cloth during NO oxidation. Carbon 2013, 54, 444-453. [CrossRef]

260. Zhu, Z.; Liu, Z.; Liu, S.; Niu, H. Adsorption and reduction of NO over activated coke at low temperature. Fuel 2000, 79, 651-658. [CrossRef]

261. Xu, L.; Li, X.-S.; Crocker, M.; Zhang, Z.-S.; Zhu, A.-M.; Shi, C. A study of the mechanism of low-temperature SCR of NO with NH3 on MnOx/CeO2. J. Mol. Catal. A Chem. 2013, 378, 82-90. [CrossRef]

262. Zhang, W.; Rabiei, S.; Bagreev, A.; Zhuang, M.; Rasouli, F. Study of NO adsorption on activated carbons. Appl. Catal. B Environ. 2008, 83, 63-71. [CrossRef]

263. Sousa, J.P.; Pereira, M.F.; Figueiredo, J.L. Catalytic oxidation of NO to NO2 on N-doped activated carbons. Catal. Today 2011, 176, 383-387. [CrossRef]

264. Wang, L.; Jia, T.-F.; Yan, X.; Li, C.-H.; Feng, L.-J. Hydrothermal synthesis of BiOBr/semi-coke composite as an emerging photo-catalyst for nitrogen monoxide oxidation under visible light. Catal. Today 2016, 264, 257-260. [CrossRef]

265. Fu, H.; Zhang, L.; Yao, W.; Zhu, Y. Photocatalytic properties of nanosized Bi2WO6 catalysts synthesized via a hydrothermal process. Appl. Catal. B Environ. 2006, 66, 100-110. [CrossRef] 
266. Zhang, Y.; Zhang, N.; Tang, Z.-R.; Xu, Y.-J. Identification of Bi 2 WO 6 as a highly selective visible-light photocatalyst toward oxidation of glycerol to dihydroxyacetone in water. Chemical Science 2013, 4, 1820-1824. [CrossRef]

267. Tang, J.; Zou, Z.; Ye, J. Photocatalytic decomposition of organic contaminants by $\mathrm{Bi}_{2} \mathrm{WO}_{6}$ under visible light irradiation. Catal. Lett. 2004, 92, 53-56. [CrossRef]

268. Sun, Z.; Guo, J.; Zhu, S.; Mao, L.; Ma, J.; Zhang, D. A high-performance $\mathrm{Bi}_{2} \mathrm{WO}_{6}$-graphene photocatalyst for visible light-induced $\mathrm{H}_{2}$ and $\mathrm{O}_{2}$ generation. Nanoscale 2014, 6, 2186-2193. [CrossRef]

269. Zhang, J.; Liu, P.; Zhang, Y.; Xu, G.; Lu, Z.; Wang, X.; Wang, Y.; Yang, L.; Tao, X.; Wang, H. Enhanced performance of nano$\mathrm{Bi}_{2} \mathrm{WO}_{6}$-graphene as pseudocapacitor electrodes by charge transfer channel. Sci. Rep. 2015, 5, 8624. [CrossRef]

270. Zhang, K.; Kim, W.; Ma, M.; Shi, X.; Park, J.H. Tuning the charge transfer route by p-n junction catalysts embedded with CdS nanorods for simultaneous efficient hydrogen and oxygen evolution. J. Mater. Chem. A 2015, 3, 4803-4810. [CrossRef]

271. Nikokavoura, A.; Trapalis, C. Graphene and g-C3N4 based photocatalysts for NOx removal: A review. Appl. Surf. Sci. 2018, 430, 18-52. [CrossRef]

272. Ai, Z.; Ho, W.; Lee, S. Efficient Visible Light Photocatalytic Removal of NO with BiOBr-Graphene Nanocomposites. J. Phys. Chem. C. 2011, 115, 25330-25337. [CrossRef]

273. Chen, M.; Huang, Y.; Yao, J.; Cao, J.-J.; Liu, Y. Visible-light-driven $\mathrm{N}-(\mathrm{BiO})_{2} \mathrm{CO}_{3} /$ Graphene oxide composites with improved photocatalytic activity and selectivity for NOx removal. Appl. Surf. Sci. 2018, 430, 137-144. [CrossRef]

274. Gao, E.; Wang, W.; Shang, M.; Xu, J. Synthesis and enhanced photocatalytic performance of graphene-Bi $2 \mathrm{WO}_{6} \mathrm{composite}$ Phys. Chem. Chem. Phys. 2011, 13, 2887-2893. [CrossRef] [PubMed]

275. Ma, H.; Shen, J.; Shi, M.; Lu, X.; Li, Z.; Long, Y.; Li, N.; Ye, M. Significant enhanced performance for Rhodamine B, phenol and Cr (VI) removal by $\mathrm{Bi}_{2} \mathrm{WO}_{6}$ nancomposites via reduced graphene oxide modification. Appl. Catal. B Environ. 2012, 121, 198-205. [CrossRef]

276. Marzo, L.; Pagire, S.K.; Reiser, O.; König, B. Visible-Light Photocatalysis: Does It Make a Difference in Organic Synthesis? Angew. Chem. Int. Ed. 2018, 57, 10034-10072. [CrossRef]

277. Chen, J.; Cen, J.; Xu, X.; Li, X. The application of heterogeneous visible light photocatalysts in organic synthesis. Catal. Sci. Technol. 2016, 6, 349-362.

278. König, B. Photocatalysis in organic synthesis-past, present, and future. Eur. J. Org. Chem. 2017, 2017, 1979-1981. [CrossRef]

279. Wang, D.; Yin, Y.; Feng, C.; Rukhsana; Shen, Y. Advances in Homogeneous Photocatalytic Organic Synthesis with Colloidal Quantum Dots. Catalysts 2021, 11, 275. [CrossRef]

280. Wang, C.-Y.; Wu, T.; Lin, Y.-W. Preparation and characterization of bismuth oxychloride/reduced graphene oxide for photocatalytic degradation of rhodamine B under white-light light-emitting-diode and sunlight irradiation. J. Photochem. Photobiol. A Chem. 2019, 371, 355-364. [CrossRef]

281. Friedmann, D.; Hakki, A.; Kim, H.; Choi, W.; Bahnemann, D. Heterogeneous photocatalytic organic synthesis: State-of-the-art and future perspectives. Green Chem. 2016, 18, 5391-5411. [CrossRef]

282. Mai, A.T.M.; Thakur, A.; Ton, N.N.T.; Nguyen, T.N.; Kaneko, T.; Taniike, T. Photodegradation of a semi-aromatic bio-derived polyimide. Polym. Degrad. Stab. 2021, 184, 109472. [CrossRef]

283. Wen, J.; Xie, J.; Chen, X.; Li, X. A review on g-C3N4-based photocatalysts. Appl. Surf. Sci. 2017, 391, 72-123. [CrossRef]

284. Rashid, J.; Karim, S.; Kumar, R.; Barakat, M.A.; Akram, B.; Hussain, N.; Bin, H.B.; Xu, M. A facile synthesis of bismuth oxychloridegraphene oxide composite for visible light photocatalysis of aqueous diclofenac sodium. Sci. Rep. 2020, 10, 14191. [CrossRef] [PubMed]

285. Zhang, M.; Gong, J.; Zeng, G.; Zhang, P.; Song, B.; Cao, W.; Liu, H.; Huan, S. Enhanced degradation performance of organic dyes removal by bismuth vanadate-reduced graphene oxide composites under visible light radiation. Colloids Surf. A Physicochem. Eng. Asp. 2018, 559, 169-183. [CrossRef]

286. Soltani, T.; Tayyebi, A.; Lee, B.-K. Enhanced photoelectrochemical (PEC) and photocatalytic properties of visible-light reduced graphene-oxide/bismuth vanadate. Appl. Surf. Sci. 2018, 448, 465-473. [CrossRef]

287. Alam, U.; Fleisch, M.; Kretschmer, I.; Bahnemann, D.; Muneer, M. One-step hydrothermal synthesis of Bi-TiO2 nanotube/graphene composites: An efficient photocatalyst for spectacular degradation of organic pollutants under visible light irradiation. Appl. Catal. B Environ. 2017, 218, 758-769. [CrossRef]

288. Chen, A.; Bian, Z.; Xu, J.; Xin, X.; Wang, H. Simultaneous removal of $\mathrm{Cr}(\mathrm{VI})$ and phenol contaminants using Z-scheme bismuth oxyiodide/reduced graphene oxide/bismuth sulfide system under visible-light irradiation. Chemosphere 2017, 188, 659-666. [CrossRef] [PubMed]

289. Lee, Y.-H.; Dai, Y.-M.; Fu, J.-Y.; Chen, C.-C. A series of bismuth-oxychloride/bismuth-oxyiodide/graphene-oxide nanocomposites: Synthesis, characterization, and photcatalytic activity and mechanism. Mol. Catal. 2017, 432, 196-209. [CrossRef]

290. Qi, K.; Qi, H.; Yang, J.; Wang, G.-C.; Selvaraj, R.; Zheng, W. Experimental and theoretical DFT+ D investigations regarding to various morphology of cuprous oxide nanoparticles: Growth mechanism of ionic liquid-assisted synthesis and photocatalytic activities. Chem. Eng. J. 2017, 324, 347-357. [CrossRef]

291. Yaseen, M.; Humayun, M.; Khan, A.; Usman, M.; Ullah, H.; Tahir, A.A. Preparation, Functionalization, Modification, and Applications of Nanostructured Gold: A Critical Review. Energies 2021, 14, 1278. [CrossRef]

292. Li, S.; Cheng, Y.; Wang, Q.; Liu, C.; Xu, L. Design, fabrication and characterization of photocatalyst Ni-doped BiVO4 for high effectively degrading dye contaminant. Mater. Res. Express 2020, 7, 115005. [CrossRef] 
293. Soltani, T.; Tayyebi, A.; Lee, B.-K. Photolysis and photocatalysis of tetracycline by sonochemically heterojunctioned BiVO4/reduced graphene oxide under visible-light irradiation. J. Environ. Manag. 2019, 232, 713-721. [CrossRef]

294. Mohanraj, J.; Durgalakshmi, D.; Rakkesh, R.A.; Balakumar, S.; Rajendran, S.; Karimi-Maleh, H. Facile synthesis of paper based graphene electrodes for point of care devices: A double stranded DNA (dsDNA) biosensor. J. Colloid Interface Sci. 2020, 566, 463-472. [CrossRef]

295. Bunpang, K.; Wisitsoraat, A.; Tuantranont, A.; Phanichphant, S.; Liewhiran, C. Effects of reduced graphene oxide loading on gas-sensing characteristics of flame-made Bi2WO6 nanoparticles. Appl. Surf. Sci. 2019, 496, 143613. [CrossRef]

296. Niyogi, S.; Bekyarova, E.; Itkis, M.E.; McWilliams, J.L.; Hamon, M.A.; Haddon, R.C. Solution properties of graphite and graphene. J. Am. Chem. Soc. 2006, 128, 7720-7721. [CrossRef] [PubMed]

297. Li, D.; Müller, M.B.; Gilje, S.; Kaner, R.B.; Wallace, G.G. Processable aqueous dispersions of graphene nanosheets. Nat. Nanotechnol. 2008, 3, 101. [CrossRef] [PubMed]

298. Hassandoost, R.; Pouran, S.R.; Khataee, A.; Orooji, Y.; Joo, S.W. Hierarchically structured ternary heterojunctions based on Ce3+/ $\mathrm{Ce} 4+$ modified $\mathrm{Fe} 3 \mathrm{O} 4$ nanoparticles anchored onto graphene oxide sheets as magnetic visible-light-active photocatalysts for decontamination of oxytetracycline. J. Hazard. Mater. 2019, 376, 200-211. [CrossRef] [PubMed]

299. Huizhong, A.; Yi, D.; Tianmin, W.; Cong, W.; Weichang, H.; ZHANG, J. Photocatalytic properties of biox (X=Cl, Br, and I). Rare Met. 2008, 27, 243-250.

300. Pare, B.; Jonnalagadda, S.; Tomar, H.; Singh, P.; Bhagwat, V. ZnO assisted photocatalytic degradation of acridine orange in aqueous solution using visible irradiation. Desalination 2008, 232, 80-90. [CrossRef]

301. Li, C.; Zhang, J.; Liu, K. A new method of enhancing photoelectrochemical characteristics of Bi/Bi2O3 electrode for hydrogen generation via water splitting. Int. J. Electrochem. Sci 2012, 7, 5028-5034.

302. Tian, N.; Zhang, Y.; Li, X.; Xiao, K.; Du, X.; Dong, F.; Waterhouse, G.I.; Zhang, T.; Huang, H. Precursor-reforming protocol to 3D mesoporous g-C3N4 established by ultrathin self-doped nanosheets for superior hydrogen evolution. Nano Energy 2017, 38, 72-81. [CrossRef] 